UNIVERSIDADE DE SÃO PAULO

INSTITUTO DE GEOCIÊNCIAS

\title{
ANÁLISE DE VORTICIDADE E MICROESTRUTURAS DA ZONA DE CISALHAMENTO CAUCAIA (SP)
}

\section{José Eduardo Sartori}

Orientador: Prof. Dr. Ginaldo Ademar da Cruz Campanha

\section{DISSERTAÇÃO DE MESTRADO}

Programa de Pós-Graduação em Geoquímica e Geotectônica 
Autorizo a reprodução e divulgação total ou parcial deste trabalho, por meio convencional ou eletrônico, para fins de estudo e pesquisa, desde que citada a fonte.

Ficha catalográfica preparada pelo Serviço de Biblioteca e Documentação do Instituto de Geociências da Universidade de São Paulo

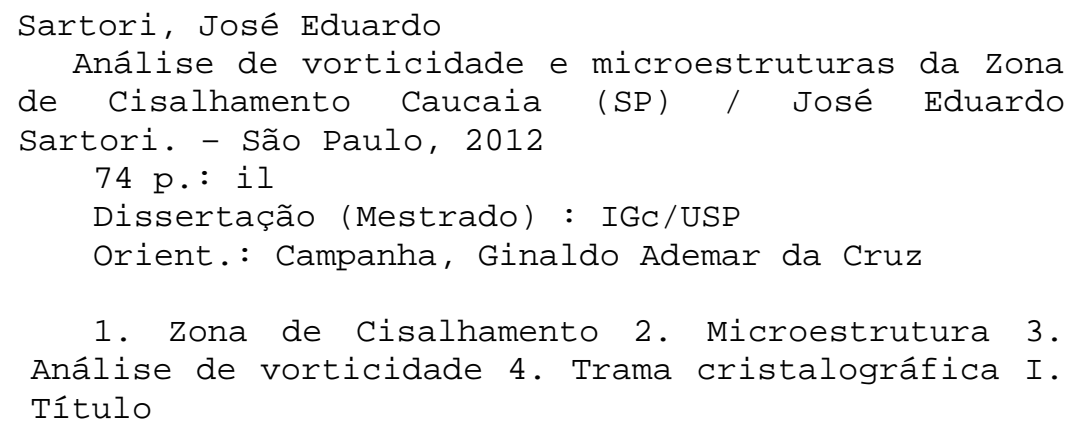

1. Zona de Cisalhamento 2. Microestrutura 3. Análise de vorticidade 4. Trama cristalográfica I. Título 


\section{AgRADECIMENTOS}

Primeiramente a Deus, pelo dom da vida e pela família que eu tenho.

Aos meus pais, José Roberto e Nilza, que são meus pilares de sustentação, por terem me criado, educado e apoiado incondicionalmente durante todos esses anos.

Ao Prof. Dr. Ginaldo Campanha pela orientação ao longo do mestrado.

Ao geólogo Dr. Frederico Meira Faleiros, por ter me ensinado a técnica de orientação cristalográfica de eixos-c de quartzo, bem como pela inestimável ajuda neste trabalho e pelas proveitosas discussões.

Ao Prof. Dr. Benjamim Bley de Brito Neves por me ajudar a arrumar moradia em São Paulo e pelas conversas e aulas sempre animadas e empolgantes.

À geóloga Angela Meira Faleiros, grande amiga desde o início da graduação na Unesp-Rio Claro, e que me acompanhou e ajudou em boa parte dos trabalhos de campo.

Aos amigos da Pós-Graduação Johanna Méndez Duque, John Mauricio Rico Bautista, Cláudia do Couto Tokashiki, Emmanuel Donald Ngonge (muitíssimo obrigado pela ajuda no Abstract), Felipe van Enck Meira, Geane Carolina Cavalcante, Luis Gustavo Viegas, Lucas Godinho (Rejeitto), Nívea Magalhães, Vicente Manjate e Alba Marina Suarez.

Não poderia deixar de agradecer também à Angélica do Laboratório de Microscopia, ao pessoal da Seção de Preparação de Amostras, Laminação e Biblioteca.

A todos vocês o meu muito obrigado! 


\section{Resumo}

O Sistema de Zonas de Cisalhamento da Região Sudeste do Brasil corresponde a um importante cinturão de cisalhamento transcorrente responsável pela estruturação do embasamento pré-cambriano do sudeste brasileiro. A Zona de Cisalhamento Caucaia (ZCC) é uma das estruturas componentes deste sistema e, a despeito da sua proximidade da capital paulista e de sua expressão, foi pouco estudada desde a sua definição, a quase 40 anos atrás. Neste sentido, o presente trabalho buscou analisar seus aspectos geométricos, cinemáticos e metamórficos, à luz de técnicas tradicionais (análise microestrutural e trama de eixos-c de quartzo) e atuais (análise de vorticidade, geotermômetro de quartzo). Deste modo, verificou-se que a Zona de Cisalhamento Caucaia apresenta orientação geral NE-SW, infletindo para E-W logo a sul do município de Tapiraí, sendo marcada por foliação milonítica vertical e lineação de estiramento de baixo ângulo caindo para NE, mostrando tratar-se de uma zona de cisalhamento transcorrente destral. O metamorfismo associado corresponde a transição entre os fácies xisto verde alto e anfibolito, com intervalo de temperatura estimado entre 400 e $600^{\circ} \mathrm{C}$. Os dados obtidos de trama cristalográfica e de análise de vorticidade indicam importante componente de cisalhamento puro no fluxo de deformação associado à ZCC. Além disso, verificou-se que a componente de cisalhamento simples variou ao longo do tempo geológico, aumentando nos últimos incrementos de deformação dúctil da Zona de Cisalhamento Caucaia, sugerindo trajetória acelerada de fluxo (accelerating flow path). Estes resultados concordam com o modelo de transpressão atualmente aceito para a formação do Sistema de Zonas de Cisalhamento da Região Sudeste do Brasil.

Palavras-chave: zona de cisalhamento, microestruturas, trama de eixos-c de quartzo, análise de vorticidade. 


\section{Abstract}

The Shear Zone System of Southeastern Brazil corresponds to an important transcurrent shear belt that produced the Precambrian basement of this region. The Caucaia Shear Zone (CSZ) is one of the component structures of this system and in spite of its nearness to the São Paulo capital and prominence, has been little studied since its definition 40 years ago. In this wise, the present study seeks to analyze its geometric, kinematic and metamorphic aspects using traditional (microstructures and quartz c-axis fabric) and modern (vorticity analysis and geothermometry of quartz) techniques. In this way, it could be seen that the Caucaia Shear Zone is NE-SW trending, with an E-W inflection at the Tapiraí city, marked by a vertical milonitic foliation and a low angle stretching lineation plunging NE, depicting a dextral transcurrent shear zone. The associated metamorphism corresponds to a transition between greenschist and amphibolite facies, with a temperature interval between $400-600^{\circ} \mathrm{C}$. The crystallographic fabric and vorticity analyses data obtained indicate important pure shear component in the flow deformation of the CSZ. Also, it could be seen that the simple shear component varied during geological time, increasing in the last ductile deformation increments of the Caucaia Shear Zone, suggesting an accelerated flow path. These results agree with the transpression model accepted today for the formation of the Shear Zone System of Southeastern Brazil.

Keywords: shear zone, microstructures, quartz c-axis fabric, vorticity analysis. 


\section{SUMÁRIO}

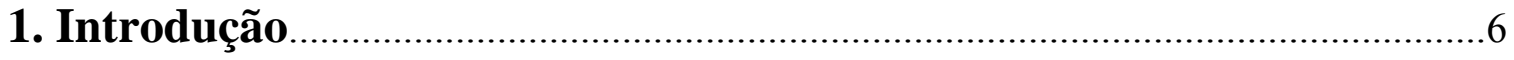

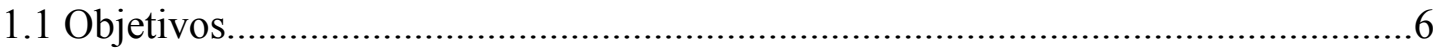

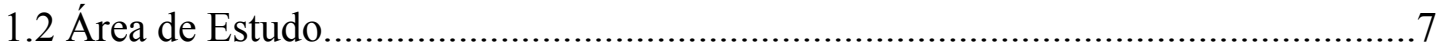

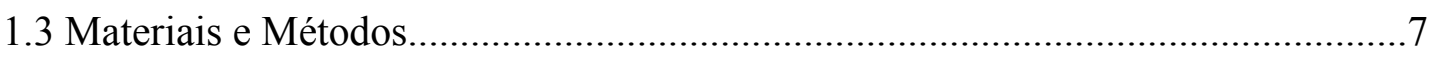

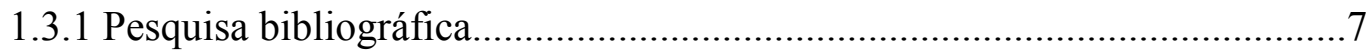

1.3.2 Interpretação de imagem de sensores remotos............................................8

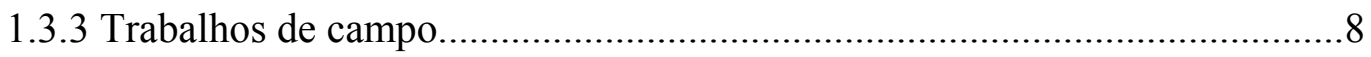

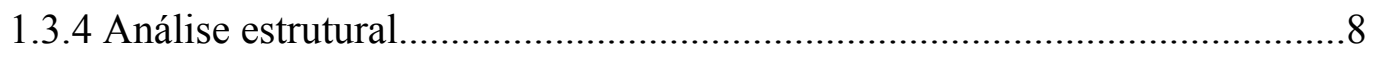

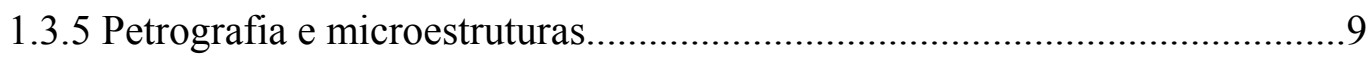

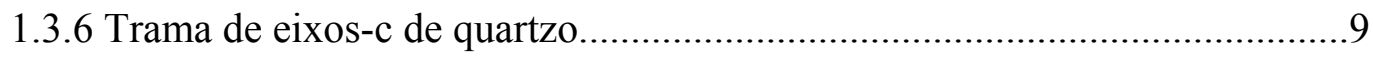

1.3.7 Análise de vorticidade........................................................................ 10

1.3.7.1 Rotação de porfiroclastos rígidos....................................................11

1.3.7.2 Razão de deformação finita/Trama de eixos-c de quartzo $\left(\mathrm{R}_{\mathrm{XZ}} / \beta\right) \ldots .12$

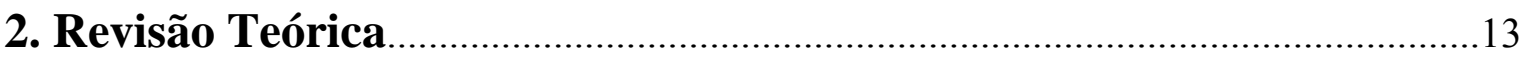

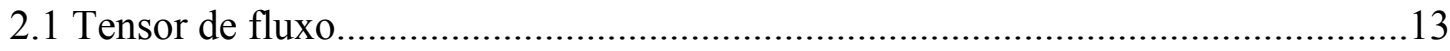

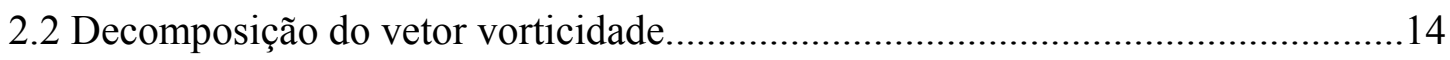

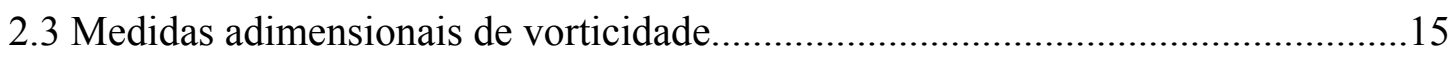

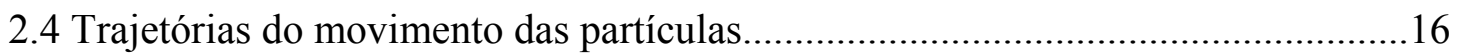

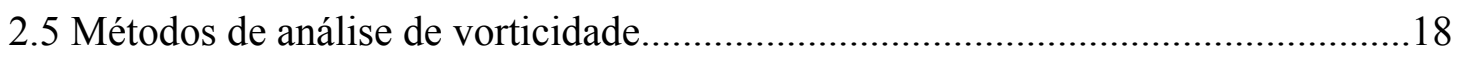

2.5.1 Rotação de Porfiroclastos Rígidos............................................................18

2.5.2 Razão de deformação finita/Trama de eixos-c de quartzo $\left(\mathrm{R}_{\mathrm{XZ}} / \beta\right)$...............20

2.6 Limitações gerais dos métodos de análise de vorticidade....................................22

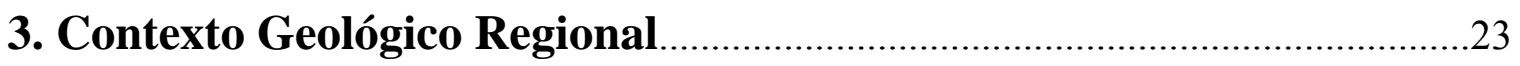

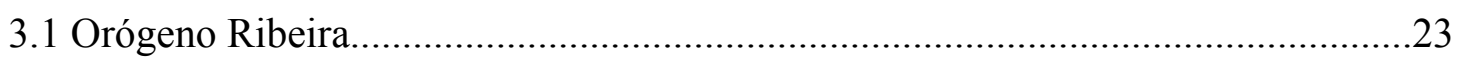

3.2 Sistema de Zonas de Cisalhamento do Sudeste do Brasil......................................25

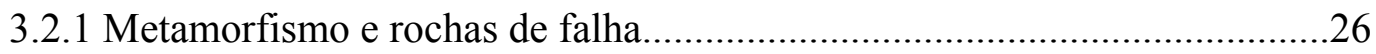

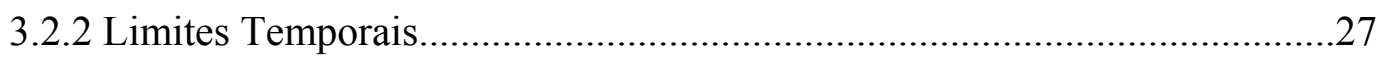

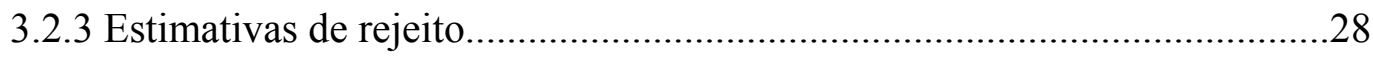

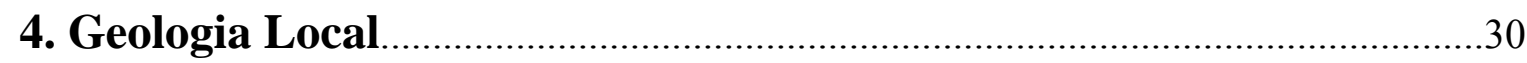

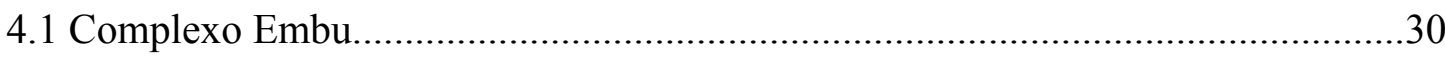

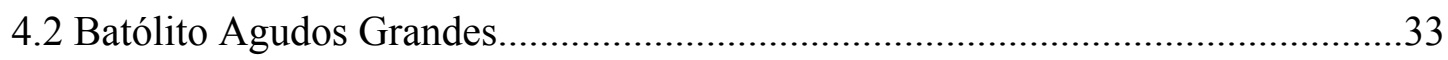

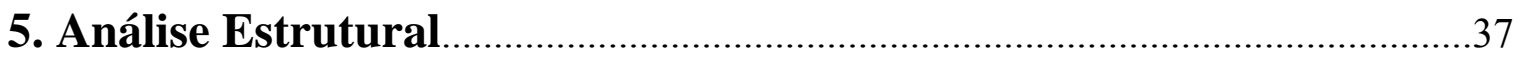

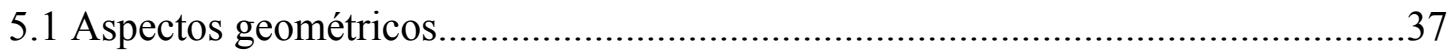

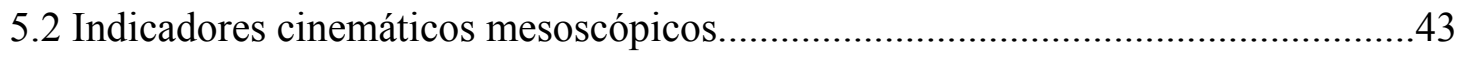

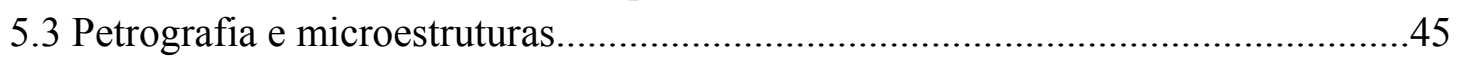

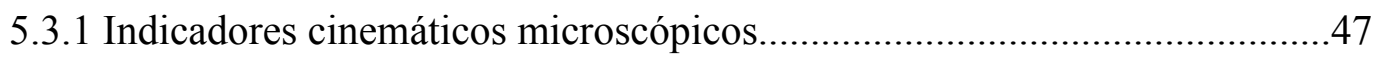




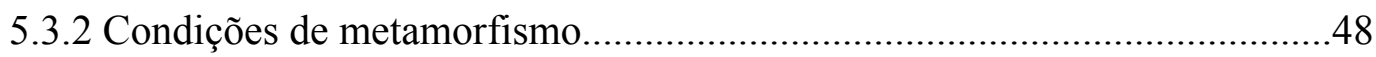

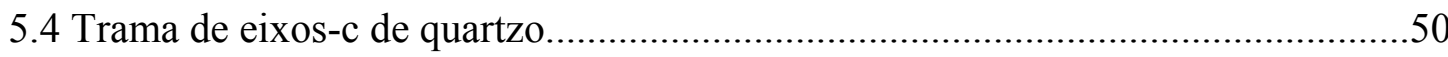

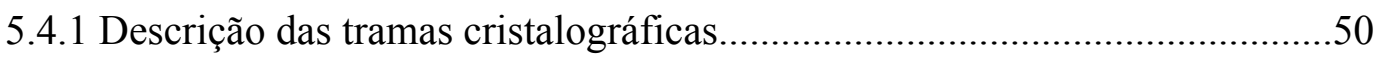

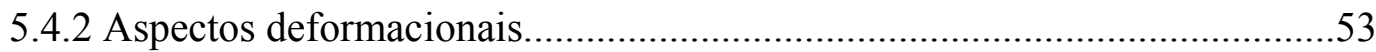

5.4.3 Sistemas de deslizamento cristalino ativados..............................................54

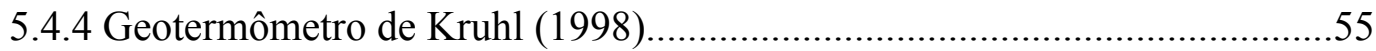

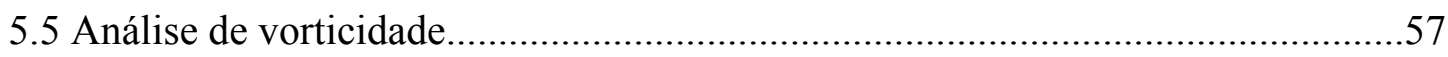

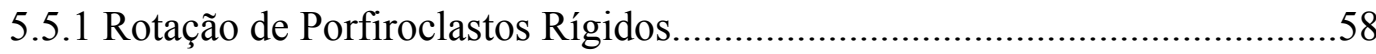

5.5.2 Razão de deformação finita/Trama de eixos-c de quartzo $\left(\mathrm{R}_{\mathrm{XZ}} / \beta\right) \ldots \ldots \ldots \ldots . . . . .60$

6. Discussão

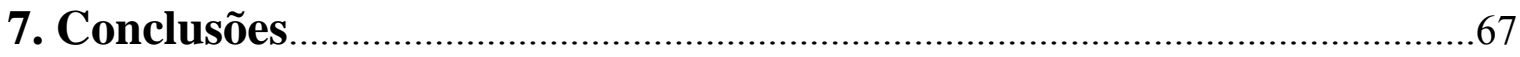

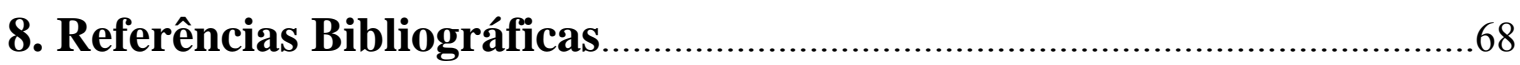




\section{INTRODUÇÃo}

A geologia pré-cambriana da região sudeste do Brasil apresenta como característica marcante a estruturação em sucessivas faixas alongadas, segundo a direção NE-SW, de rochas supracrustais, do embasamento retrabalhado e de arco magmático (Heilbron et al., 2004). Essa geometria é produto da ação de uma importante rede de zonas de cisalhamento transcorrentes predominantemente destrais. O conjunto destas estruturas constitui um cinturão de cisalhamento transcorrente com mais de $1.000 \mathrm{~km}$ de extensão e $200 \mathrm{~km}$ de largura, com rejeito estimado da ordem de centenas de quilômetros (Campanha, 2002), que chega a justapor terrenos com histórias metamórficas, deformacionais e geocronológicas completamente distintas, complexa colagem de terrenos suspeitos e exóticos. Isto complica sobremaneira as correlações estratigráficas regionais e dificulta tentativas de reconstruções paleogeográficas. Este conjunto foi denominado de Sistema de Zonas de Cisalhamento da Região Sudeste do Brasil (Campanha, 2002).

Uma das estruturas deste sistema corresponde a Zona de Cisalhamento Caucaia, definida por Hasui (1973) a sudoeste da cidade de São Paulo e, desde então, pouco estudada, a despeito de sua proximidade com a capital paulista e de sua expressão em campo, onde chega a desenvolver faixa de rochas intensamente deformadas de quase 1.000 $\mathrm{m}$ de largura.

Recentemente, maior importância tem sido atribuída à Zona de Cisalhamento Caucaia, tida como limite entre os terrenos Apiaí, a norte, e Embu, a sul (Campanha e Sadowski, 1999; Campos Neto, 2000). Isto é reforçado por diferenças marcantes no registro magmático a norte e a sul da referida estrutura, que separa granitóides de contextualizações tectônicas distintas (Janasi e Ulbrich, 1991; Janasi e Lima, 2003).

\subsection{Objetivos}

Este trabalho tem como escopo o estudo da Zona de Cisalhamento Caucaia e de sua influência sobre as estruturas regionais, definindo suas características geométricas e cinemáticas. Buscou-se determinar os mecanismos de deformação associados ao desenvolvimento das faixas miloníticas, bem como as condições físicas em que estas ocorreram. Por fim, estudou-se a cinemática de fluxo da Zona de Cisalhamento Caucaia, através da aplicação de técnicas cristalográficas e de análise de vorticidade. 


\section{2 Área de Estudo}

A área estudada no presente trabalho abrange parte dos municípios de São Paulo, Embu, Cotia, Ibiúna, Piedade e Tapiraí, no sudeste paulista (Figura 1.1). A região é limitada pelos paralelos $23^{\circ} 30^{\prime}$ e $24^{\circ} 04^{\prime}$ de latitude sul, e meridianos $46^{\circ} 37^{\prime}$ e $47^{\circ} 41^{\prime}$ de longitude oeste.

O acesso à área é feito, a partir de São Paulo, através da rodovia Raposo Tavares (SP-270) até Vargem Grande Paulista, rodovia Bunjiro Nakao (SP-250) passando por Ibiúna e Piedade, e rodovia Padre Guilherme Hovel (SP-079) até Tapiraí. Além disso, várias estradas secundárias, asfaltadas e de terra, possibilitam a locomoção pela região.

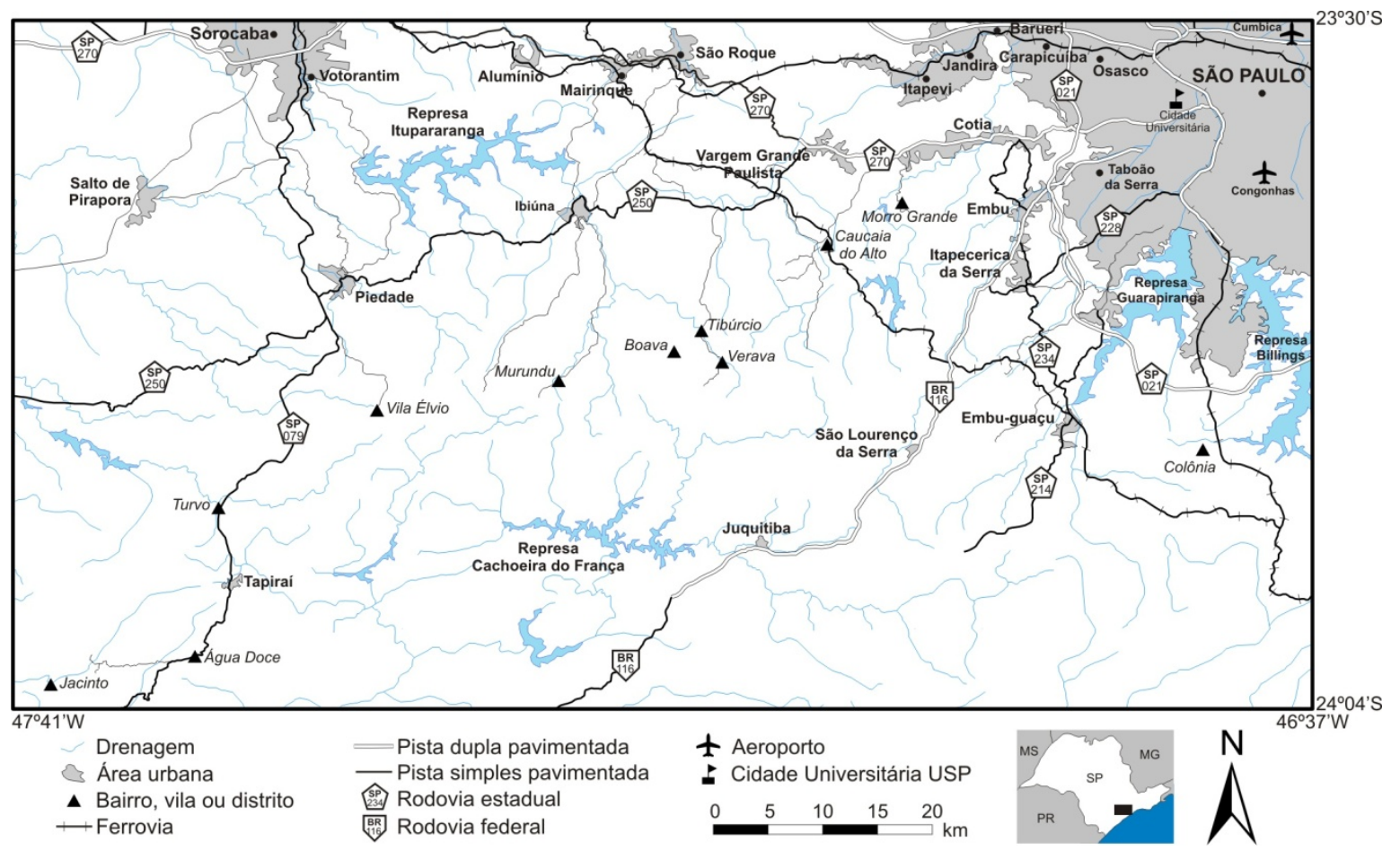

Figura 1.1. Mapa de localização da área de estudo.

\subsection{Materiais e Métodos}

Neste capítulo são apresentados os procedimentos utilizados para alcançar os objetivos propostos.

\subsubsection{Pesquisa bibliográfica}

Nesta primeira etapa foram pesquisados trabalhos anteriores realizados na área de estudo, com levantamento, integração e compilação de mapas e dados geológicos já existentes. 
Também foram abordados trabalhos relativos a cada método específico utilizado como ferramenta na obtenção de informações sobre cinemática e mecanismos de deformação em zonas de cisalhamento.

\subsubsection{Interpretação de imagem de sensores remotos}

Esta etapa envolveu a interpretação geológico-estrutural da região estudada, feita através da análise de modelos digitais de elevação, obtidos a partir de dados de interferometria de radar baseado em satélite (SRTM, USGS/NASA) utilizando-se o software Global Mapper, versão 9.0. Deste modo, foram traçados os lineamentos de relevo associados à Zona de Cisalhamento Caucaia. Este produto serviu como guia para a seleção de perfis e áreas que foram investigados em maior detalhe nos trabalhos de campo.

Adicionalmente, os modelos digitais de elevação, juntamente com os dados de campo, serviram para corrigir/refinar o traçado da zona de cisalhamento estudada, que foi baseada inicialmente em mapas geológicos de escala regional (1:750.000 e 1:250.000)

\subsubsection{Trabalhos de campo}

Foram estudados 131 afloramentos, nos quais se procurou descrever os litotipos observados, bem como levantar dados estruturais importantes como a orientação de foliações, lineações e indicadores cinemáticos, a fim de realizar a análise estrutural. Além disso, foram coletadas amostras para os estudos petrográficos, microestruturais, de orientação cristalográfica preferencial (trama de eixos-c de quartzo) e de vorticidade.

Durante esta etapa de trabalho foram feitas seções perpendiculares e caminhamentos longitudinais à Zona de Cisalhamento Caucaia. Deste modo, foi possível documentar os aspectos estruturais das rochas dentro e fora da área de influência da zona de cisalhamento.

\subsubsection{Análise estrutural}

A partir das informações coletadas em campo, procedeu-se à análise estrutural, feita através da aplicação de técnicas convencionais (Turner e Weiss, 1963; Hobbs et al., 1976; Ramsay e Huber, 1983, 1987). Os dados levantados foram tratados em mapas, perfis e estereogramas, conforme métodos usuais, com hierarquização dos elementos estruturais a partir de critérios de superposição, estilo e relações da trama com minerais metamórficos. 
As estruturas associadas à Zona de Cisalhamento de Caucaia foram tratadas em escala macro, meso e microscópica, e integradas seguindo procedimentos propostos por Ramsay e Graham (1970), Ramsay (1980), Ramsay e Huber (1987), entre outros autores.

\subsubsection{Petrografia e microestruturas}

A partir das amostras coletadas em campo, foram confeccionadas 60 seções delgadas, referentes a 37 afloramentos descritos. Procurou-se, quando possível, cortar as amostras segundo o plano perpendicular à foliação principal da rocha e paralela à lineação de estiramento, ou seja, paralelamente ao plano XZ do elipsóide de deformação finita. Este material foi estudado ao microscópio petrográfico convencional, procurando identificar as paragêneses metamórficas associadas ao cisalhamento. Tal procedimento visa determinar as condições de pressão e temperatura em que se desenvolveu a deformação.

Também foram caracterizadas amostras coletadas fora da faixa de deformação associada à Zona de Cisalhamento Caucaia. Assim, foi possível separar os elementos da petrotrama decorrentes da deformação cisalhante, daqueles oriundos do padrão regional.

Por fim, procedeu-se a análise qualitativa de microestruturas baseada principalmente no trabalho de Passchier e Trouw (2005). Este tipo de estudo permitiu inferir os mecanismos de deformação atuantes, estimar o intervalo de temperatura em que ocorreu a deformação cisalhante, bem como definir o sentido do movimento da zona de cisalhamento através de indicadores cinemáticos.

\subsubsection{Trama de eixos-c de quartzo}

Nesta etapa de trabalho foram analisadas nove seções delgadas de milonitos e protomilonitos pertencentes à Zona de Cisalhamento Caucaia. As amostras foram cortadas paralelamente ao plano XZ de deformação finita, ou seja, perpendicular à foliação milonítica e paralela à lineação de estiramento.

Através do uso de uma platina universal de quatro eixos acoplada a um microscópio óptico convencional, foi medida a orientação do eixo-c de pouco mais de duzentos grãos de quartzo por amostra. Os procedimentos utilizados nas medições são detalhadamente descritos em Wahlstrom (1969) e Santoro (1998).

As medidas de orientação dos eixos-c de quartzo foram inseridas em uma planilha eletrônica, onde foram corrigidas e rotacionadas. Tais dados foram lançados como linhas em estereogramas de igual área, projeção no hemisfério inferior (rede de Schmidt- 
Lambert), e representados por curvas de isofrequência, através do software Stereo32, versão 1.0.3.

Nos estereogramas, a apresentação padrão da trama cristalográfica é feita com o eixo principal intermediário (Y) de deformação finita na vertical, e os eixos X e Z paralelos às direções E-W e N-S, respectivamente. A foliação milonítica e a lineação de estiramento são tomadas como referência, sendo representadas no estereograma como um plano vertical de direção E-W (plano de achatamento principal) e uma linha horizontal paralela ao eixo $\mathrm{X}$, respectivamente.

As tramas cristalográficas obtidas são comparadas com padrões estabelecidos na literatura (Lister, 1977; Lister e Dornsiepen, 1982; Schmid e Casey, 1986), o que permite inferir aspectos da deformação progressiva. No caso de deformação por cisalhamento simples pode-se inferir o sentido de rotação, indicado pela assimetria do padrão resultante. A assimetria interna está relacionada à forma do padrão em si, e à concentração preferencial de eixos-c ao longo de uma direção ou plano específico. Já a assimetria externa é considerada com relação a um referencial externo, geralmente o plano de foliação e a lineação (Passchier e Trouw, 2005).

Analisando a trama cristalográfica foi possível identificar a posição dos máximos e submáximos de concentração de eixos-c. Isto permite estimar quais os sistemas de deslizamento cristalino foram ativados durante a deformação do quartzo e, consequentemente, inferir intervalos de temperatura de metamorfismo.

Por fim, foram separadas as tramas cristalográficas em guirlanda cruzada e medidos os ângulos de abertura entre as guirlandas. Tais dados foram lançados no gráfico que correlaciona ângulo de abertura e temperatura de metamorfismo, que constitui o geotermômetro de Kruhl (1998), modificado por Law et al. (2004). Assim, as temperaturas obtidas por este método foram comparadas com aquelas indicadas pelos sistemas de deslizamento cristalino ativado e microestruturas observadas.

\subsubsection{Análise de vorticidade}

Há vários métodos de análise de vorticidade descritos na literatura, como compilado por Xypolias (2010). Dentre estes, dois foram selecionados para serem aplicados às rochas miloníticas da Zona de Cisalhamento Caucaia: rotação de porfiroclastos rígidos e razão de deformação finita/trama de eixos-c de quartzo. 


\subsubsection{Rotação de Porfiroclastos Rígidos}

Foram selecionadas oito amostras orientadas de milonitos e protomilonitos graníticos pertencentes à Zona de Cisalhamento Caucaia. Os exemplares foram cortados e laminados perpendicularmente à foliação milonítica e paralelamente à lineação de estiramento, ou seja, segundo o plano $\mathrm{XZ}$ de deformação finita. Em seguida, as seções delgadas foram fotografadas ao microscópio óptico convencional, com polarizadores cruzados e paralelos. A partir das fotos, procedeu-se a digitalização manual dos porfiroclastos. Para tanto, utilizou-se o software Corel Draw ${ }^{\circledR}$ versão X3, gerando como produto uma imagem tipo raster.

O arquivo de imagem foi tratado no programa SPO2003 (Launeau e Robin, 2003) versão 6/2011, o qual associou uma elipse a cada um dos porfiroclastos desenhados, através da aplicação do método do tensor de inércia. O referido método foi desenvolvido para análise de tramas magmáticas, porém, adequa-se muito bem ao estudo de tramas de rochas deformadas, como mostrado por Rodrigues e Faleiros (2007). O produto deste processo corresponde a uma planilha eletrônica com dados de dimensões e orientação para cada um dos porfiroclastos, bem como valores médios e erros associados.

É importante mencionar que a orientação dos porfiroclastos corresponde ao ângulo entre o eixo maior deste e o traço do plano de fluxo. Segundo Xypolias (2010), para rochas fortemente deformadas o traço do plano de fluxo pode ser considerado como paralelo à direção da cauda reta dos porfiroclastos manteados. Entretanto, a maioria dos estudos toma o plano de foliação milonítica como referência, pois em altas deformações este último tende a ser paralelo ao plano de fluxo. A despeito dessa discussão, em todas as lâminas analisadas, ambas as feições microestruturais são aproximadamente paralelas.

$\mathrm{O}$ passo seguinte corresponde à análise do comportamento rotacional dos porfiroclastos. Para tanto, adotou-se a técnica da Razão de Forma dos Porfiroclastos (Porphyroclast Aspect Ratio) de Passchier (1987), porém, seguindo a abordagem mais simples e intuitiva proposta por Wallis et al. (1993). Assim, a partir dos dados da planilha eletrônica, fez um gráfico do ângulo de orientação $(\varphi)$ em função da razão de forma/elipsidade $(\mathrm{R})$ dos porfiroclastos. Este gráfico permite a identificação de dois campos distintos: um composto por porfiroclastos de menor razão de forma e que rotacionam livremente; e outro campo com porfiroclastos de maior razão de forma e que tendem a atingir a posição de equilíbrio. 
O limite entre os dois campos supracitados define a razão de forma crítica $\left(\mathrm{R}_{\mathrm{C}}\right)$, que aplicada na equação de Passchier (1987), fornecerá o valor do número médio de vorticidade $\left(\mathbf{W}_{\mathbf{m}}\right)$ :

$$
W_{m}=\frac{\left(R_{C}^{2}+1\right)}{\left(R_{C}^{2}-1\right)}
$$

\subsubsection{Razão de deformação finita/Trama de eixos-c de quartzo $\left(\mathrm{R}_{\mathrm{XZ}} / \beta\right)$}

Foram selecionadas as amostras que resultaram em tramas de eixos-c de quartzo em guirlandas simples e cruzada tipo I assimétricas. Em seguida, procedeu-se com a medida do ângulo $(\beta)$ entre a perpendicular ao segmento central da guirlanda e o plano de achatamento finito (plano de foliação milonítica). Como a guirlanda geralmente não é perfeitamente definida, adotou-se um erro mínimo de $2^{\circ}$ para o ângulo $\beta$, como sugerido por Xypolias (2010).

O próximo passo corresponde à estimativa da razão de deformação finita principal $\left(\mathrm{R}_{\mathrm{XZ}}\right)$. Para tanto, foram utilizados os métodos do tensor de inércia (Launeau e Cruden, 1998), Rf/ $\varphi$ (Ramsay e Huber, 1983; Mulchrone e Meere, 2001) e de Fry (Ramsay e Huber, 1983). Procurou-se, sempre que possível, estimar a razão de deformação finita do quartzo da matriz das rochas miloníticas, entretanto, em alguns casos foi necessário utilizar os porfiroclastos de feldspato, o que fornece uma estimativa mínima do valor da razão de deformação.

Por fim, de posse dos dados, foi possível inferir os valores do número médio de vorticidade $\left(\mathbf{W}_{\mathbf{m}}\right)$, através do uso da equação proposta por Wallis (1995):

$$
W_{m}=\frac{R_{X Z}+1}{R_{X Z}-1} \times \sin \left\{\tan ^{-1}\left[\frac{\sin (2 \beta)}{\frac{R_{X Z}+1}{R_{X Z}-1}-\cos (2 \beta)}\right]\right\}
$$




\section{REVISÃO TEÓRICA}

Desde os trabalhos pioneiros de Ramsay e Graham (1970) e Ramsay (1980), as zonas de cisalhamento passaram a ser tratadas como estreitas faixas de rochas intensamente deformadas em regime dúctil. Além disso, o modelo ideal de cisalhamento simples passou a ser o paradigma das zonas de cisalhamento.

Estudos de trama cristalográfica, realizados sobretudo na década de 80 , inferiram que a deformação ao longo de zonas de cisalhamento naturais não decorria estritamente de cisalhamento simples progressivo, envolvendo também uma componente de cisalhamento puro (Schmid e Casey, 1986). A identificação desta componente no fluxo é importante, pois, pode provocar deformação (stretching) do material paralelamente aos limites da zona.

Neste contexto, surge o conceito de vorticidade, que constitui uma medida da nãocoaxialidade, ou seja, da quantidade relativa de rotação que um determinado tipo de fluxo possui (Passchier e Trouw, 2005; Borges, 2010). Deste modo, conhecer a vorticidade de rochas naturalmente deformadas, bem como a sua distribuição espaço-temporal é importante no estudo da cinemática do fluxo em zonas de cisalhamento, que constitui aspecto fundamental para compreender a evolução tectônica da crosta terrestre (Xypolias, 2010).

\subsection{Tensor de fluxo}

O tensor de fluxo ou gradiente de velocidade (L) descreve o campo de velocidade ao redor de uma determinada partícula em um instante de tempo qualquer, e pode ser escrita da seguinte maneira, considerando sistema de coordenadas cartesiano:

$$
\boldsymbol{L}_{i j}=\frac{\partial v_{i}}{\partial x_{j}} \quad i, j=1,2,3
$$

A equação do gradiente de velocidade relacionado é dada por:

$$
v_{i}=L_{i j} x_{j} \text {, onde } v_{\mathrm{i}} \text { é a velocidade na coordenada espacial } x_{\mathrm{j}} \text {. }
$$

Um fluxo é considerado homogêneo quando o tensor vorticidade (L) é independente da posição no espaço, ou seja, ele se mantém invariável ao longo de todo o volume da rocha durante a deformação. Além disso, um fluxo que não varia no tempo é dito em estado quase-estacionário (steady state).

O tensor de fluxo $\mathbf{L}$ pode ser decomposto em duas partes: um tensor simétrico $\mathbf{D}$, referente às componentes de deformação (stretching tensor); e um tensor anti-simétrico $\mathbf{W}$, 
relacionado à componente rotacional (rotational tensor) do fluxo (Lister e Williams, 1983).

$$
L=D+W
$$

No caso geral, há uma componente extra, referente à translação do campo de velocidade. Entretanto, este termo é anulado ao se fixar o sistema de coordenadas na partícula analisada.

A partir do tensor deformação (D), simétrico, podem ser obtidos três auto-vetores denominados eixos de deformação instantânea (Instantaneous Stretching Axis - ISA $A_{1,2,3}$ ) do fluxo. Além disso, há três autovalores que correspondem às taxas de deformação principais (stretching rates $-\mathrm{s}_{\mathrm{a}, \mathrm{b}, \mathrm{c}}$ ) das linhas materiais instantaneamente paralelas aos ISAs, podendo ter qualquer magnitude.

O tensor vorticidade $(\mathbf{W})$ descreve a velocidade angular $(\omega)$ das partículas ou linhas materiais de um corpo em deformação, com relação a um sistema de coordenadas. Como o tensor vorticidade é anti-simétrico, ele pode ser simplesmente expresso por um vetor: o vetor vorticidade (w), cujo comprimento/magnitude define a vorticidade $(w)$ do fluxo. O plano normal ao vetor vorticidade é denominado plano seccional de vorticidade (Vorticity Profile Plane - VPP).

Matematicamente, tem-se que o vetor vorticidade é igual ao rotacional da velocidade, ou corresponde ao dobro do vetor velocidade angular (Means et al., 1980):

$$
\vec{w}=\vec{\nabla} \times \vec{v} \quad \text { ou } \quad \vec{w}=2 . \vec{\omega}
$$

\subsection{Decomposição do vetor vorticidade}

O vetor vorticidade (w) pode ser decomposto, com relação a um referencial externo, frequentemente geográfico, em:

- Vorticidade interna ou induzida por cisalhamento $\left(\mathbf{w}_{\mathbf{i}}\right)$ - corresponde à rotação das linhas materiais em relação aos ISAs;

- Spin externo ou vorticidade rígida $(\mathbf{\Omega})$ - resulta da rotação dos eixos de deformação instantânea, juntamente com todas as linhas materiais, com relação a uma referência externa.

A vorticidade interna $\left(\mathbf{w}_{\mathbf{i}}\right)$ é medida com relação a marcadores que servem com sistema de referência interno como, por exemplo, o limite da zona de cisalhamento. Esta componente da vorticidade decorre da deformação não-coaxial, e influencia diretamente a geometria da trama das rochas miloníticas (Xypolias, 2010). 
Por sua vez, a rotação dos eixos de deformação instantânea e da zona de cisalhamento como um todo é produto da vorticidade rígida, sendo equivalente a rotação de corpo rígido sobre um eixo. Esta componente da vorticidade não afeta a geometria da petrotrama, logo, não provoca mudanças na não-coaxialidade (Means, 1994).

A adoção de uma referência que permanece paralela ou em ângulo fixo com os eixos de deformação instantânea é muito útil, uma vez que, a componente de vorticidade rígida é anulada, simplificando a descrição do fluxo.

$$
\vec{w}=\overrightarrow{w_{l}}+\vec{\Omega} \stackrel{\vec{\Omega}=\overrightarrow{0}}{\longrightarrow} \vec{w}=\overrightarrow{w_{l}}
$$

A orientação do vetor vorticidade $(\mathbf{w})$ em relação aos eixos de deformação instantânea (ISAs) controla a simetria do fluxo (Figura 2.1). Assim, em fluxos simples o vetor vorticidade permanece paralelo a um dos ISAs, o que acarreta em simetria monoclínica ou superior, daí a denominação de fluxo monoclínico (Passchier, 1998). Caso não haja paralelismo com nenhum dos eixos de deformação instantânea, considera-se o fluxo como triclínico (Robin e Cruden, 1994).

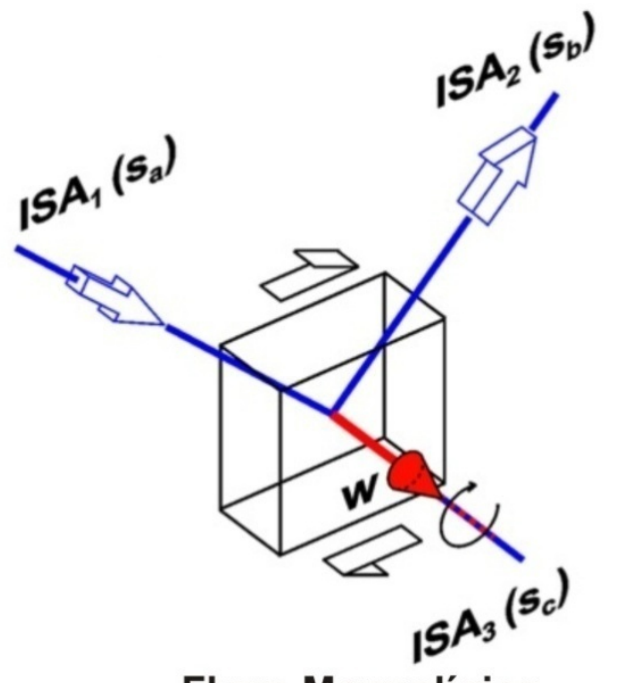

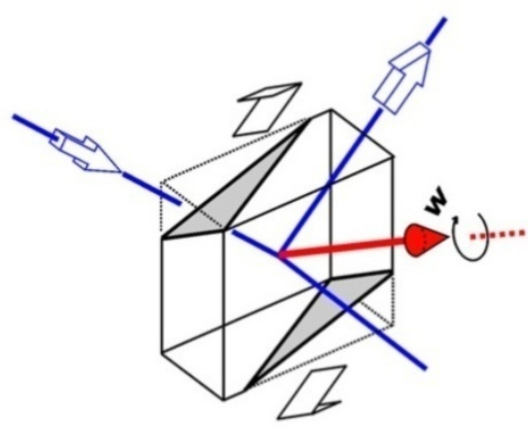

Fluxo Triclínico

Fluxo Monoclínico

Figura 2.1. Orientação do vetor vorticidade (w), em relação aos ISAs para fluxo monoclínico e triclínico (modificado de Xypolias, 2010).

\subsection{Medidas adimensionais de vorticidade}

A despeito da discussão acima sobre o vetor vorticidade, é padrão o uso do número de vorticidade $\left(\mathrm{W}_{\mathrm{K}}\right)$. A razão por trás disso é que o número de vorticidade é normalizado pelas taxas de deformação instantânea principais $\left(\mathrm{s}_{\mathrm{a}, \mathrm{b}, \mathrm{c}}\right)$, resultando em um número adimensional. 


$$
W_{K}=\frac{w_{i}}{\sqrt{2 \cdot\left(s_{a}^{2}+s_{b}^{2}+s_{c}^{2}\right)}}
$$

Isto o torna mais adequado na comparação direta com diferentes tipos de fluxo, do que propriamente o vetor vorticidade (Passchier e Trouw, 2005). Assim, a análise de vorticidade pode ser definida como a avaliação numérica do tipo de fluxo de cisalhamento, através do uso de dados estruturais e de petrotrama (Xypolias, 2010).

O número de vorticidade pode ser maior ou igual a zero, com grau de nãocoaxialidade aumentando com valores crescentes de $\mathrm{W}_{\mathrm{K}}$. Fluxos por cisalhamento puro e simples são indicados por número de vorticidade nulo e unitário, respectivamente. Valores intermediários de $\mathrm{W}_{\mathrm{K}}$ entre zero e um caracterizam cisalhamento geral (general shear). Número de vorticidade superior a um indica cisalhamento super simples (super-simple shear), e quando $\mathrm{W}_{\mathrm{K}}$ tende a infinito tem-se o caso de rotação de corpo rígido.

Em zonas de cisalhamento naturais, a vorticidade do fluxo pode variar no espaço e no tempo. Nestes casos é mais apropriado o emprego do número médio de vorticidade (mean kinematic vorticity number $-\mathrm{W}_{\mathrm{m}}$ ), que considera uma média da vorticidade do fluxo integrado sobre espaço e tempo. Para deformação em estado quase-estacionário, tem-se a igualdade entre $\mathrm{W}_{\mathrm{K}}$ (deformação instantânea) e $\mathrm{W}_{\mathrm{m}}$ (deformação finita).

Fluxos tridimensionais portadores de simetria monoclínica permitem simplificações no número de vorticidade cinemática, pois o fluxo pode ser efetivamente descrito ao longo do plano seccional de vorticidade (VPP). Se o vetor vorticidade é paralelo ao $I S A_{3}$, pode-se definir o número de vorticidade seccional $\left(\mathrm{W}_{\mathrm{n}}\right)$ :

$$
W_{n}=\frac{w}{2 \cdot s_{m}} \rightarrow W_{n}=\frac{w}{s_{b}-s_{a}}
$$

\subsection{Trajetórias do movimento das partículas}

As trajetórias de partículas (particles path), ou linhas de fluxo, são curvas abertas ou fechadas que representam a mudança progressiva da posição das partículas durante a deformação. A geometria das trajetórias é devidamente caracterizada por dois parâmetros: o número de vorticidade seccional $\left(\mathrm{W}_{\mathrm{n}}\right)$ e o número de dilatação seccional $\left(\mathrm{A}_{\mathrm{n}}\right)$, que descreve mudanças instantâneas de área no plano seccional de vorticidade.

Os padrões de linhas de fluxo podem ser classificados em quatro tipos (Figura 2.2): hiperbólico, paralelo, circular ou elíptico, e radial centrípeto (inward radiant) ou centrífugo (outward radiant). 
O padrão de fluxo hiperbólico, observado em deformações por cisalhamento puro e geral (general shear), é caracterizado por duas linhas de fluxo retas, que são assíntotas às hipérboles, definindo a orientação das linhas materiais que não rotacionam, em relação aos ISAs, durante a deformação progressiva. Estas linhas irrotacionais correspondem aos autovetores do tensor de fluxo $(\mathbf{L})$, sendo denominadas apófises $\left(A_{1,2}\right)$ quando o fluxo não apresenta vorticidade rígida (Xypolias, 2010).

As apófises controlam a geometria do fluxo e, para fluxos de padrão hiperbólico, elas são reconhecidas como apófise de encurtamento $\left(A_{1}\right)$ ou extensional $\left(A_{2}\right)$, dependendo se elas "repelem" ou "atraem" as linhas materiais no fluxo, respectivamente. Daí a razão da apófise extensional ser referida como atrator de trama (fabric attractor) de fluxo por Passchier (1997).

O padrão de fluxo paralelo apresenta duas apófises coincidentes ou paralelas, exceto no caso de número de dilatação seccional $\left(\mathrm{A}_{\mathrm{n}}\right)$ extremo, positivo ou negativo. E, por sua vez, linhas de fluxo com padrão elíptico não possuem apófise, porém, são controladas por linhas imaginárias denominadas vetores-fantasma (ghostvectors) por Iacopini et al. (2010).

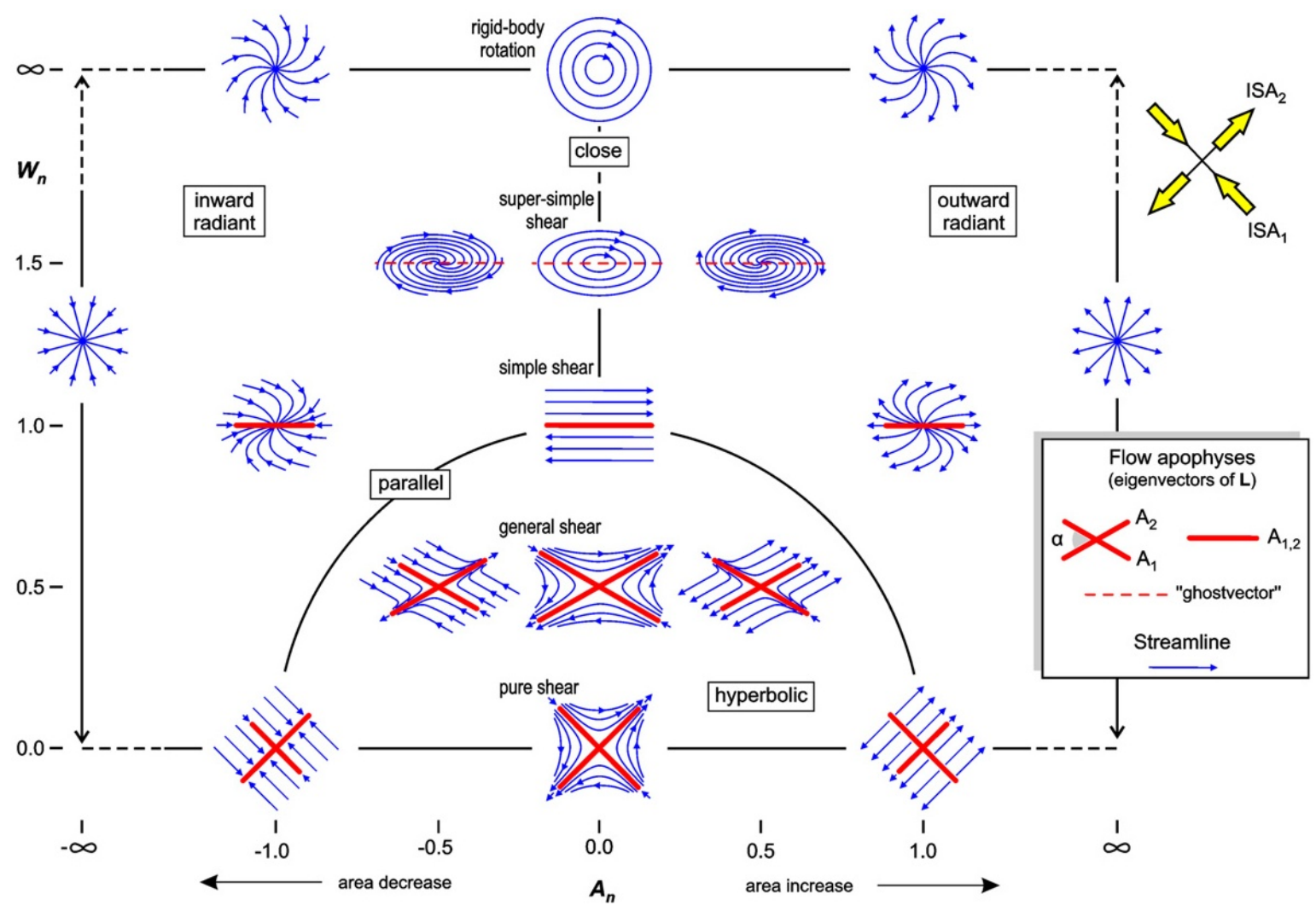

Figura 2.2. Padrões de linhas de fluxo para fluxos bidimensionais em estado quase-estacionário, considerando o número de vorticidade seccional $\left(\mathrm{W}_{\mathrm{n}}\right)$ e número de dilatação seccional $\left(\mathrm{A}_{\mathrm{n}}\right)$. Extraído de Xypolias (2010). 
O ângulo $(\alpha)$ entre as apófises de fluxo varia sempre entre $0^{\circ}$ e $90^{\circ}$, e depende exclusivamente do número de vorticidade seccional $\mathrm{W}_{\mathrm{n}}($ Passchier, 1986):

$$
W_{n}=\cos (\alpha)
$$

Assim, as apófises de fluxo são ortogonais para fluxo por cisalhamento puro $\left(\mathrm{W}_{\mathrm{n}}=0\right)$, formam ângulo agudo para cisalhamento geral $\left(0<\mathrm{W}_{\mathrm{n}}<1\right)$ e são paralelas, quando há cisalhamento simples $\left(\mathrm{W}_{\mathrm{n}}=1\right)$. O comportamento não linear entre o número de vorticidade seccional e a proporção relativa entre as componentes coaxial e não-coaxial de deformação é mostrado na figura 2.3. Sendo que o caso intermediário entre cisalhamento simples e puro ocorre em $\mathrm{W}_{\mathrm{n}}=0,71\left(\alpha=45^{\circ}\right)$.

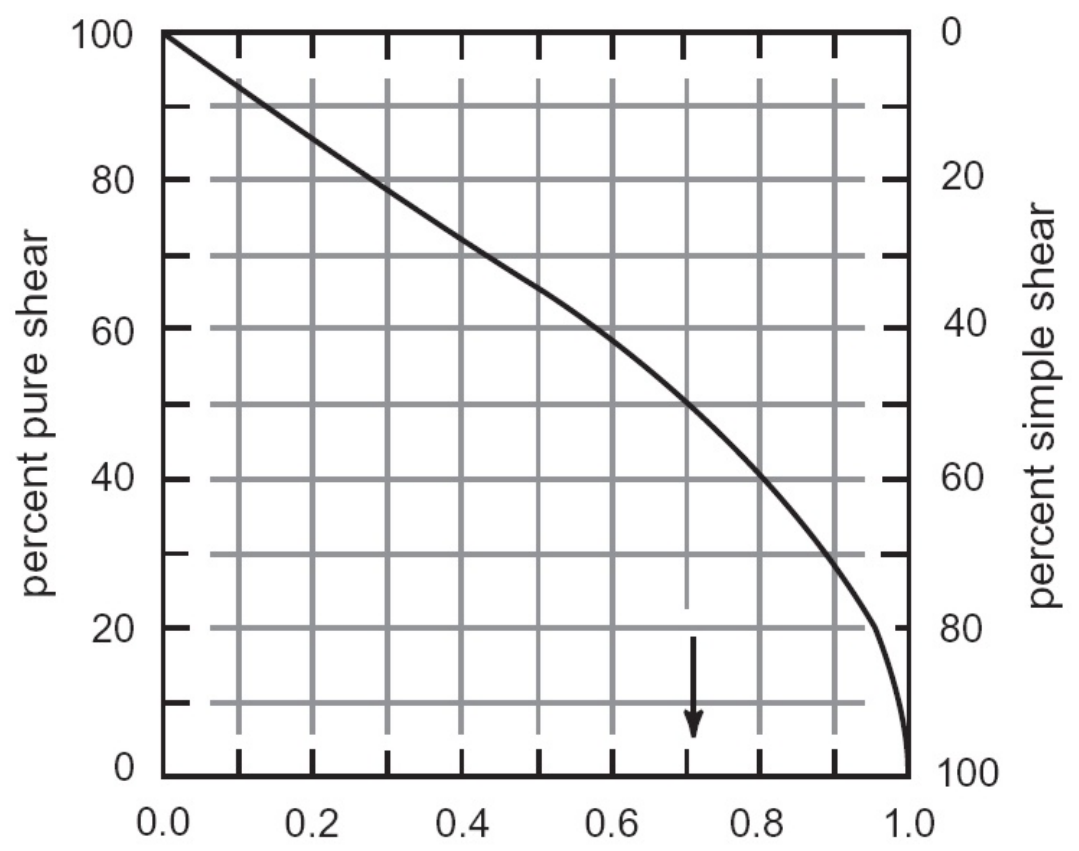

Figura 2.3. Gráfico mostrando a relação entre o número de vorticidade $\left(\mathrm{W}_{\mathrm{K}}\right)$ e as componentes de cisalhamento puro e simples, para fluxos bidimensionais instantâneos. Extraído de Law et al. (2010).

\subsection{Métodos de análise de vorticidade}

Neste estudo foram utilizados dois indicadores (gauges) de vorticidade: rotação de porfiroclastos rígidos e trama de eixos-c de quartzo. Embora estes dois métodos assumam simetria monoclínica (no mínimo), elas são válidas para deformações tridimensionais gerais, e não requerem condições de deformação plana (Law et al., 2004).

\subsubsection{Rotação de Porfiroclastos Rígidos}

Este método se fundamenta no comportamento de partículas rígidas (porfiroclastos) em meio a uma matriz que se deforma ductilmente. Para tanto, considera-se o modelo 
teórico de Jeffery (1922), segundo o qual os porfiroclastos comportam-se como elipsóides rígidos perfeitamente ligados à matriz que, durante a deformação, age como um fluido linear newtoniano.

O modelo de Jeffery (1922) prevê que, no caso de deformação por cisalhamento simples, os porfiroclastos são rotacionados contínua e sinteticamente à direção de cisalhamento. No caso do cisalhamento geral (general shear), nem todas as partículas rígidas são livres para rotacionar continuamente, nem todos os objetos giram sinteticamente à direção de cisalhamento (Ghosh e Ramberg, 1976; Passchier, 1987). Neste caso, o comportamento dos clastos depende da sua razão de forma, orientação inicial, e do número médio de vorticidade cinemática $\left(\mathrm{W}_{\mathrm{m}}\right)$. Deste modo, a análise da orientação de uma população de porfiroclastos rígidos em uma rocha deformada plasticamente pode ser utilizada como um indicador (gauge) de vorticidade.

Existem três técnicas de estudo do comportamento rotacional dos porfiroclastos, cuja diferença fundamental está na forma como os dados são representados. A técnica da Razão de Forma dos Porfiroclastos (Porphyroclast Aspect Ratio) de Passchier (1987) utiliza um gráfico cartesiano convencional, enquanto a Distribuição Hiperbólica dos Porfiroclastos (Porphyroclast Hyperbolic Distribution) de Simpson e De Paor (1997) emprega uma rede hiperbólica. Por fim, o Rigid Grain Net (Jessup et al., 2007) utiliza um gráfico cartesiano com semi-hipérboles calculadas para diferentes números de vorticidade $\left(\mathrm{W}_{\mathrm{K}}\right)$.

Neste trabalho adotou-se a técnica da razão de forma dos porfiroclastos, seguindo a abordagem simples e intuitiva proposta por Wallis et al. (1993). A análise é feita em um gráfico cartesiano do ângulo entre o eixo maior do porfiroclasto e o plano de fluxo, em função da razão de forma/elipsidade do mesmo (gráfico de $\varphi \times$ R, Figura 2.4). A partir da distribuição dos dados é possível distinguir dois conjuntos:

(1) conjunto formado por porfiroclastos de pequena elipsidade, que se distribuem em uma ampla gama de ângulos de orientação, pois podem rotacionar livremente. Geralmente, são porfiroclastos manteados tipo $\delta$;

(2) conjunto formado por porfiroclastos de maior elipsidade, orientados segundo um restrito intervalo angular. Estes clastos rotacionam, tendendo a se aproximar assintoticamente da posição de equilíbrio. Geralmente, correspondem a porfiroclastos manteados tipo $\sigma$. 


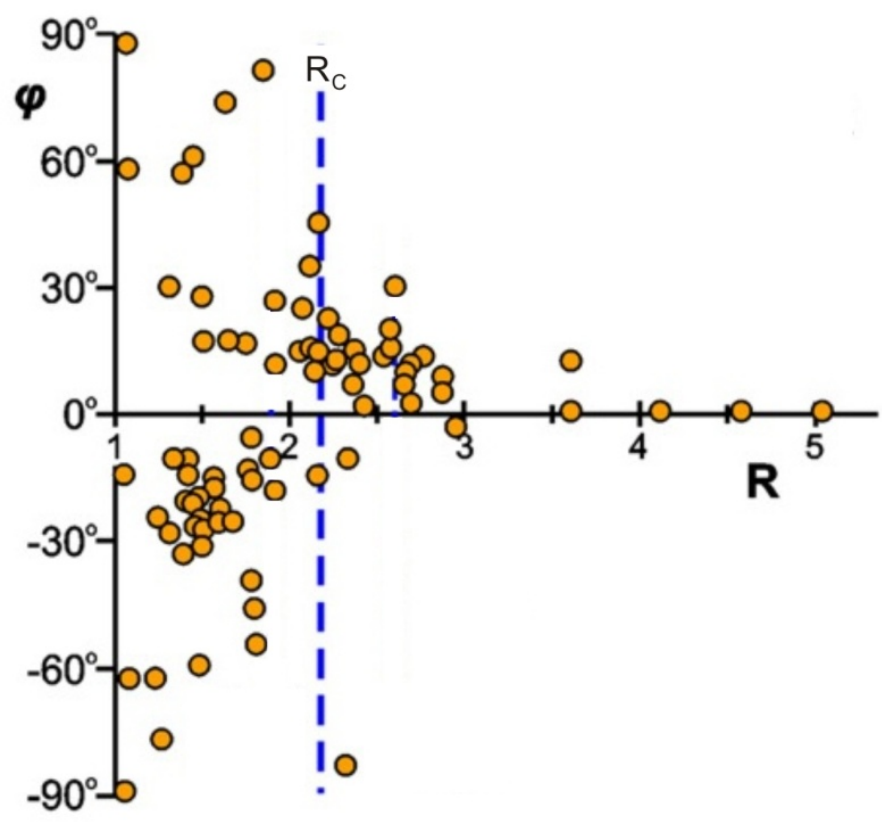

Figura 2.4. Gráfico do ângulo de orientação $(\varphi)$ em função da razão de forma $(R)$, mostrando a razão de forma crítica $\left(\mathrm{R}_{\mathrm{C}}\right)$ que separa o conjunto dos porfiroclastos que rotacionam livremente, daqueles que tendem à posição de equilíbrio. Modificado de Xypolias (2010).

O limite entre os dois conjuntos define a razão de forma crítica $\left(R_{C}\right)$, a partir da qual se estima o valor do número médio de vorticidade $\left(\mathrm{W}_{\mathrm{m}}\right)$ através da aplicação da equação de Passchier (1987):

$$
W_{m}=\frac{\left(R_{C}^{2}+1\right)}{\left(R_{C}^{2}-1\right)}
$$

\subsubsection{Razão de deformação finita/Trama de eixos-c de quartzo $\left(\mathrm{R}_{X Z} / \beta\right)$}

Este método de análise de vorticidade se aplica a tectonitos caracterizados por tramas de eixos-c de quartzo em guirlanda simples e cruzada tipo I, e se baseia no fato da assimetria da guirlanda ser controlada pelo número médio de vorticidade e pela deformação finita (Platt e Behrmann, 1986).

Durante uma deformação com $0 \leq \mathrm{W}_{\mathrm{m}} \leq 1$, em estado quase-estacionário, o eixo principal máximo de deformação rotaciona tendendo a se paralelizar com o plano de fluxo (apófise extensional $\mathrm{A}_{2}$ ) com o incremento de strain, ou se mantém paralelo a ele, no caso de cisalhamento puro. Enquanto isso, o segmento central da guirlanda de eixos-c se estabiliza perpendicularmente ao plano de fluxo (Figura 2.5), como mostram simulações computacionais feitas por Lister e Hobbs (1980) e é assumido por vários autores (Platt e Behrmann, 1986; Wallis, 1995). 
Baseado nas observações acima, Wallis (1995) mostrou que, conhecendo-se a razão de deformação finita principal $\left(\mathrm{R}_{\mathrm{XZ}}\right)$ e o ângulo $(\beta)$ entre a foliação e a perpendicular ao segmento central da guirlanda de eixos-c, pode-se determinar o número médio de vorticidade $\left(\mathrm{W}_{\mathrm{m}}\right)$, através da aplicação da equação:

$$
W_{m}=\frac{R_{X Z}+1}{R_{X Z}-1} \cdot \sin \left\{\tan ^{-1}\left[\frac{\sin (2 \beta)}{\frac{R_{X Z}+1}{R_{X Z}-1}-\cos (2 \beta)}\right]\right\}
$$

Um aspecto crucial para a exatidão do número de vorticidade obtido neste método é a suposição central de que a trama cristalográfica do quartzo se mantém em uma orientação estável em relação ao referencial externo. Segundo Xypolias (2010), há evidências experimentais, numéricas e observacionais que sustentam esta suposição. Entretanto, Heilbronner e Tullis (2006 apud Xypolias, 2010) realizaram experimentos envolvendo cisalhamento geral em quartzo, e constataram que o segmento central da guirlanda tende a rotacionar sinteticamente à direção de cisalhamento, com o aumento do strain e da recristalização dinâmica, acarretando na produção de tramas oblíquas ao plano de cisalhamento. Nestes casos, o método $\mathrm{R}_{\mathrm{XZ}} \beta$ tende a superestimar o valor do número de vorticidade (Law, 2010).
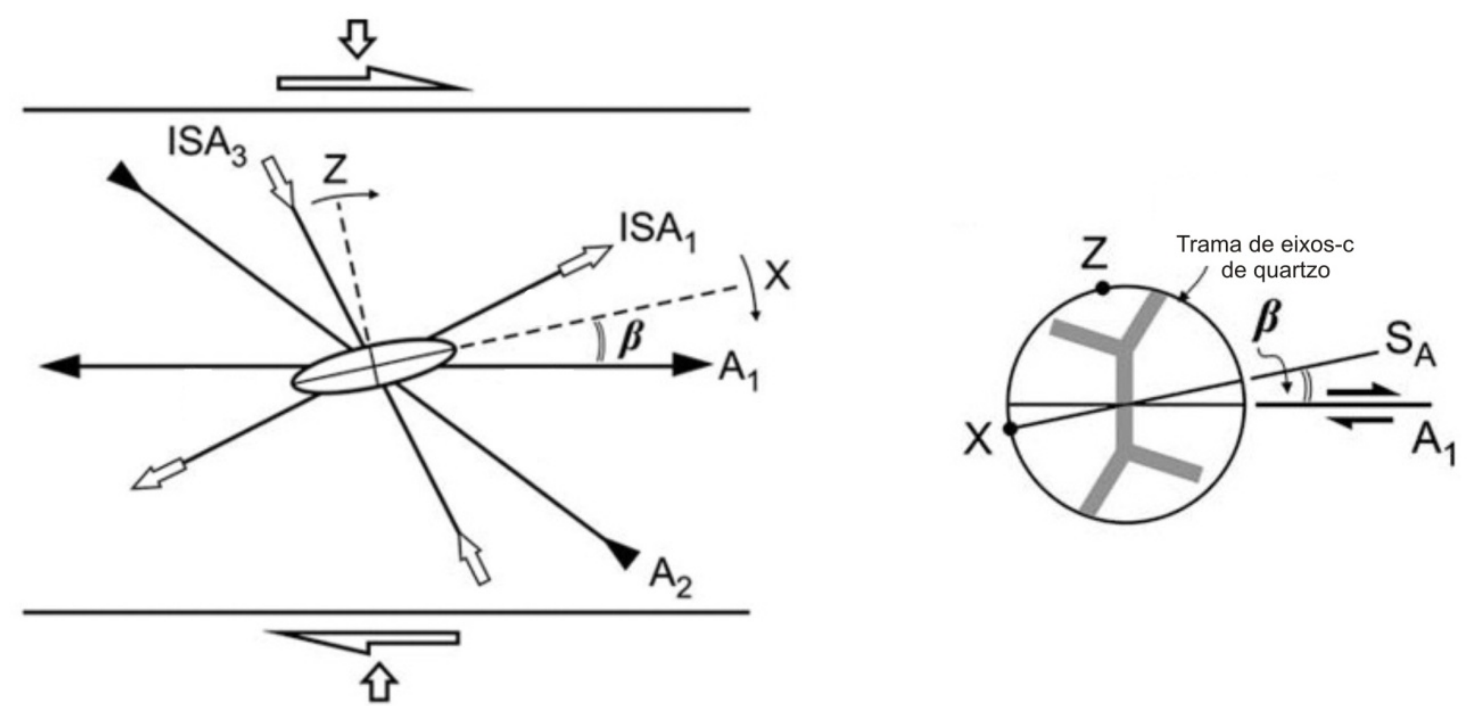

Figura 2.5. Esquema simplificado mostrando a orientação relativa dos elementos de fluxo instantâneo e suas relações angulares no espaço, considerando fluxo por cisalhamento geral destral. Modificado de Xypolias (2009). 


\subsection{Limitações gerais dos métodos de análise de vorticidade}

A maioria dos trabalhos analíticos de análise de vorticidade é limitada a fluxos homogêneos e em estado quase-estacionário, devido à descrição matemática mais simples. Entretanto, é amplamente aceito que a deformação na natureza é justamente o contrário do adotado nestes modelos.

O problema da heterogeneidade é superado ao se aplicar conceitos da mecânica dos meios contínuos. Assim, subdivide-se o volume de rocha em porções infinitesimais onde o fluxo pode ser considerado homogêneo e, posteriormente, processa-se a integração ao longo de todo o material deformado. A questão de o fluxo ser considerado em estado quase-estacionário ainda é problemática, uma vez que pouco se sabe sobre a trajetória do fluxo (flow path) na deformação progressiva (Xypolias, 2010).

Segundo o mesmo autor, todos os métodos de análise de vorticidade baseiam-se em observações e medidas ao longo do plano de deformação finita principal (XZ), considerado como paralelo ao plano seccional de vorticidade (VPP). Isto pressupõe que o vetor vorticidade seja paralelo a um dos ISAs (fluxo monoclínico) e ao eixo principal intermediário $\mathrm{Y}$ de deformação finita.

A suposição de fluxo monoclínico é problemática, uma vez que zonas de cisalhamento podem ser desenvolvidas por fluxos de simetria triclínica. Além disso, considera-se o fluxo monoclínico como exceção, e não como regra, em zonas fortemente deformadas (Jiang e Williams, 1998 apud Xypolias, 2010). Como conseqüência, o plano seccional de vorticidade não seria necessariamente perpendicular ao eixo de simetria da trama, logo, as estimativas de vorticidade não seriam acuradas.

Por fim, a deformação ao longo de zonas de cisalhamento litologicamente heterogêneas pode resultar em partição de deformação entre camadas de competência contrastante. Neste caso, o número de vorticidade pode variar de camada para camada, mesmo se a geometria do fluxo permanecer constante durante a deformação progressiva (Xypolias, 2010). 


\section{ConteXto Geológico Regional}

A Plataforma Sul-americana é composta por uma série de blocos e núcleos cratônicos amalgamados por uma complexa trama de cinturões de dobramento neoproterozóicos. Os principais núcleos cratônicos (Amazônico, São Francisco, São LuísOeste África, Luís Alves e Rio de La Plata) são derivados de crosta continental antiga, correspondendo a fragmentos remanescentes do supercontinente Rodínia, com variado nível de preservação (Basei et al., 2010).

Segundo os mesmos autores, os cinturões de dobramento podem ser organizados em termos de dois ciclos orogênicos: um no Toniano (Orogênese Cariris Velhos entre 1000 e $930 \mathrm{Ma}$, e Mara Rosa entre 920 e $860 \mathrm{Ma}$ ), e outra pós-Toniana a Cambro-ordoviciana (Orogênese Brasiliana-Panafricana).

Durante o Ciclo Orogênico global Brasiliano-Panafricano ocorreram sucessivas colisões e docagem de terrenos, que resultaram na última amalgamação dos escudos antigos para formar o supercontinente Gondwana. No sudeste do Brasil são reconhecidos dois sistemas orogênicos principais (Campos Neto, 2000):

- Sistema Orogênico Tocantins - está relacionado ao fechamento do paleoceano Goianides, um oceano Toniano situado a oeste da placa São Francisco. Este sistema engloba os cinturões Brasília, Paraguai-Araguaia e Alto Rio Grande;

- Sistema Orogênico Mantiqueira - está relacionado ao fechamento do paleoceano Adamastor, um antigo oceano limitado pelas placas Congo-São Francisco e Kalahari. É composto pelos orógenos Araçuaí, Ribeira, Dom Feliciano, São Gabriel, e pela zona de interferência entre os orógenos Brasília e Ribeira.

\subsection{Orógeno Ribeira}

O Orógeno Ribeira é um orógeno colisional de trend estrutural NE-SW resultante da colisão oblíqua entre a placa Congo-São Francisco e outras placas/microplacas (Paranapanema, Serra do Mar e Cabo Frio) e arcos de ilhas, relacionada com a assembléia de Gondwana Ocidental no Neoproterozóico. Como consequência desta colisão, ocorreu a partição da deformação principal entre zonas de encurtamento frontal e zonas com componente transpressiva destral, produzindo empurrões com mergulhos superiores a $30^{\circ}$ e zonas de cisalhamento oblíquas, respectivamente (Heilbron et al., 2004). 
Na parte sul do Orógeno Ribeira a estruturação é controlada por um sistema de zonas de cisalhamento transcorrente longitudinal, tardio e de escala crustal. Estas estruturas delimitam terrenos justapostos, com diferentes padrões litológicos, estruturais, metamórficos e geocronológicos, sugerindo uma complexa colagem tectônica de terrenos suspeitos e exóticos. Abrangendo a área de estudo, os principais terrenos envolvidos são o Apiaí e o Embu.

Segundo Faleiros et al. (2011), o Terreno Apiaí é formado pela amalgamação de outros terrenos de idade Calimiana (idades U-Pb em zircão, ca. 1.450 - 1.500 Ma.), Toniana (idades U-Pb em zircão, ca. 900 - 1.000 Ma.) e Ediacarana (idades U-Pb em zircão, ca. 630 - 580 Ma.), compostos por depósitos remanescentes de bacias retro-arco, plataforma carbonática, turbiditos, flysch, depósitos de águas profundas associados a magmatismo básico. A exposição de porções de embasamento paleoproterozóico é rara, e correspondem a núcleos de ortognaisses estaterianos, localmente intrusivos em gnaisses tardi-riacianos aflorando no núcleo de antiformas. As unidades metassedimentares deste terreno apresentam metamorfismo tipo Barroviano variando de fácies xisto verde baixo a anfibolito médio.

O Terreno Embu é limitado a noroeste com o Terreno Apiaí, pelas zonas de cisalhamento Caucaia-Rio Jaguari e acunha-se com o Terreno Juiz de Fora, a nordeste. O Terreno Embu diferencia-se dos demais, pela natureza e idade de seu embasamento e magmatismo, bem como pela idade mais antiga de seu metamorfismo.

As unidades supracrustais são compostas por metassedimentos dominados por mica xistos e paragnaisses migmatíticos de idade de sedimentação desconhecida, que correspondem ao Complexo Embu (Hasui, 1975a; Hasui e Sadowski, 1976). O metamorfismo principal é de fácies anfibolito, zona da sillimanita-muscovita, gradando longitudinalmente à zona da sillimanita-feldspato potássico, com anatexia (Vieira, 1996), cuja idade é estimada em ca. $790 \mathrm{Ma}$. (U-Th-Pb em monazita; Vlach, 2001). Cordani et al. (2002) reportou uma idade U-Pb em zircão de 811 \pm 13 Ma. para um gnaisse do Complexo Embu, mostrando antiga atividade do Ciclo Orogênico Brasiliano para este terreno.

O magmatismo neoproterozóico no Terreno Embu é dominado por tipos que variam entre biotita granito inequigranular a porfirítico e muscovita-biotita monzogranito equigranular, com idade estimada de 594 \pm 21 Ma. (U-Th-Pb em monazita; Vlach, 2001). Uma característica marcante deste magmatismo é a ausência de granitos francamente metaluminosos, como os hornblenda-biotita granitos porfiríticos que são expressivos nos 
terrenos vizinhos (Janasi e Ulbrich, 1991), como no Batólito Agudos Grandes do Terreno Apiaí. Isto confere importância tectônica para a Zona de Cisalhamento Caucaia.

\subsection{Sistema de Zonas de Cisalhamento da Região Sudeste do Brasil}

Como visto anteriormente, a geologia das regiões sudeste e sul do Brasil é marcada por sucessivas faixas alongadas de rochas supracrustais, do embasamento retrabalhado e de arco magmático, limitadas por extensas zonas de cisalhamento (Heilbron et al., 2004) dominantemente transcorrentes destrais. O conjunto destas zonas de cisalhamento configura um cinturão de cisalhamento de aproximadamente $1.100 \mathrm{~km}$ de comprimento por $200 \mathrm{~km}$ de largura, com orientação segundo a direção ENE, denominado por Campanha (2002) de Sistema de Zonas de Cisalhamento da Região Sudeste do Brasil.

O Sistema de Zonas de Cisalhamento da Região Sudeste do Brasil possui grande importância na compartimentação litoestrutural, estratigráfica e tectônica dos segmentos norte e central do Sistema Orogênico Mantiqueira, uma vez que, muitas destas zonas de cisalhamento correspondem a paleosuturas, ou seja, antigos limites de placas litosféricas ou terrenos.

Este sistema deflete as estruturas orientadas N-S provenientes da Bahia, leste de Minas Gerais e Espírito Santo, que passam a ENE na região de São Paulo e Rio de Janeiro, e retomam a orientação geral N-S no sul do Brasil indo até o Uruguai. Em toda esta região a linha de costa é paralela às estruturas, mostrando sua importância no processo de separação dos continentes sul-americano e africano durante o Cretáceo, configurando um típico caso de herança tectônica.

Dentre as zonas de cisalhamento componentes do Sistema de Zonas de Cisalhamento do Sudeste, as mais expressivas são as de Taxaquara, Cubatão, Alto da Fartura, Buquira, Caucaia e Jundiuvira (Figura 3.1). Todas estas se caracterizam por apresentarem faixa de rochas deformadas com espessura da ordem de $1.000 \mathrm{~m}$ ou superior.

Duas grandes estruturas foram consideradas como importantes limites crustais: a megafalha Além Paraíba-Cubatão-Itapeúna-Lancinha, com mais de 1.000 km de extensão e que constituiria o eixo principal do sistema transcorrente, e a megaestrutura JundiuviraBuquira-Rio Preto.

Considerando as grandes estruturas supracitadas, tem-se que o Sistema de Zonas de Cisalhamento do Sudeste pode ser dividido em três setores: norte, central e sul. O setor 
central possui 50 a $100 \mathrm{~km}$ de largura, e é caracterizado por foliação verticalizada e lineação de estiramento sub-horizontal, configurando tectonitos SL (Campanha, 2002). Em direção aos setores norte e sul, a estruturação apresenta mergulhos moderados a baixos, chegando a sub-horizontais em seus centros. Assim, tem-se uma estrutura regional em leque aberto, com as porções centrais fortemente verticalizadas interpretada como uma macro-flor positiva (Machado e Endo, 1993), ou uma estrutura sinclinorial (Almeida 2000).

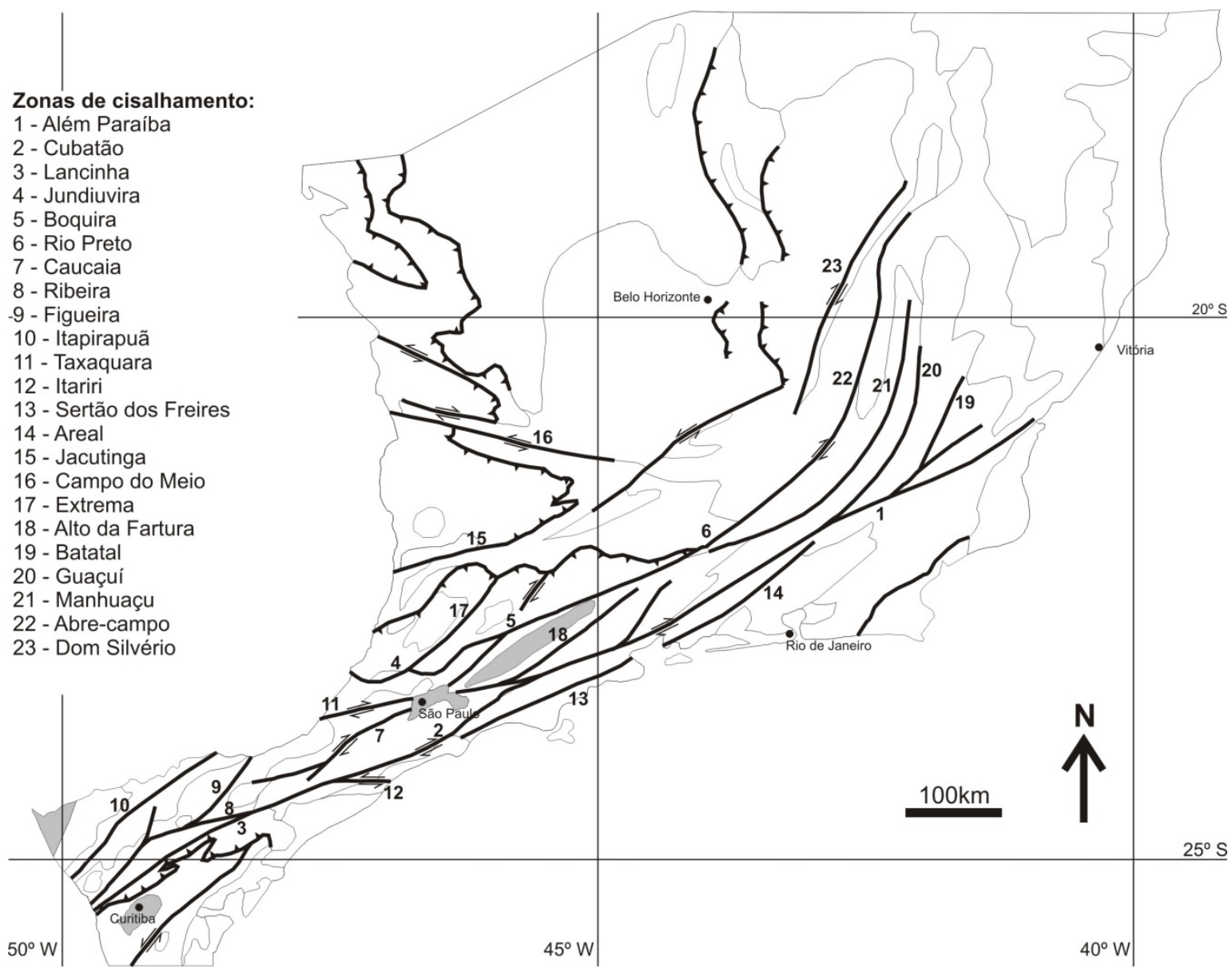

Figura 3.1. Quadro geral do sistema de zonas de cisalhamento do sudeste do Brasil, destacando algumas das principais estruturas.

Almeida (2000), por sua vez, considera que a zona de cisalhamento Arcádia-Areal seria um limite crustal mais importante no Rio de Janeiro, propondo a megafalha ArcádiaAreal-Sertão dos Freires-Cubatão.

\subsubsection{Metamorfismo e Rochas de Falha}

$\mathrm{Na}$ faixa deformada principal associada ao Sistema de Zonas de Cisalhamento do Sudeste são documentadas rochas de falha essencialmente miloníticas, evidenciando 
deformação de natureza dúctil. Assim, segundo Campanha (2002), predominando os tipos milonítico, ultramilonítico e blastomilonítico.

O Sistema de Zonas de Cisalhamento do Sudeste expõe rochas deformadas em diferentes níveis crustais, evidenciada pelas paragêneses metamórficas sin-miloníticas observadas na matriz recristalizada dos milonitos. Tal fato é bem registrado na megafalha Além Paraíba-Cubatão-Itapeúna-Lancinha que, de maneira simplificada, varia desde alto grau metamórfico (fácies granulito) no estado do Rio de Janeiro, passando para os fácies anfibolito e xisto verde alto no Vale do Paraíba, chegando a baixo grau no limite São Paulo e Paraná (Campanha, 2002).

Em algumas das zonas de cisalhamento do Sistema de Zonas de Cisalhamento do Sudeste, como Taxaquara, Cubatão, Rio Jaguari, são registradas rochas cataclásticas. Isto indica reativação destas estruturas em regime de deformação rúptil, associada a níveis crustais mais rasos.

\subsubsection{Limites Temporais}

A história evolutiva do Sistema de Zonas de Cisalhamento do Sudeste não é totalmente conhecida, mas, seguramente, o sistema foi ativo durante o Ciclo Orogênico Brasiliano-Panafricano. Segundo Campanha (2002), muitas evidências sugerem que o período de implantação destas estruturas tenha ocorrido entre 0,6 e 0,5 Ga.

Datações diretas dos milonitos, através dos métodos K-Ar e Ar-Ar de micas finas na matriz dessas rochas, indicam idades de $534 \pm 16$ Ma. para a Zona de Cisalhamento Lancinha-Cubatão (Basei, inédito), 520 Ma. para a Zona de Cisalhamento Jacutinga-Ouro Fino-Três Corações (Hackspacher et al., 2004) e de 500 - 490 Ma. para a zona de cisalhamento Cubatão/Itariri (Passareli et al., 2011).

Zuquim et al. (2011) obtiveram idade de 586,9 $\pm 8,7$ Ma. para a Zona de Cisalhamento Maria da Fé, através de datações U/Pb SHRIMP em zircão de diques considerados sin-cinemáticos à falha.

Schmitt et al. (2004) analisaram milonitos de zonas de cisalhamento (NE-SW) transcorrentes destrais dentro do Terreno Cabo Frio e obtiveram idades entre 505 e 490 Ma. (método U-Pb em monazita e zircão).

O final da fase de implantação do Sistema de Zonas de Cisalhamento do Sudeste é estimado em 0,5 Ga. (Campanha 1980, 1981), idade obtida através de datação K-Ar de biotitas presentes em diques de pegmatito que cortam a Zona de Cisalhamento Além 
Paraíba. Segundo Campanha (2002), este limite temporal superior é reforçado pelas idades das bacias molássicas da região, relacionadas com as últimas etapas da evolução do sistema transcorrente, provavelmente em um regime de bacias de afastamento (pull-apart). Dados geocronológicos indicam idade de sedimentação entre 606 e 530 Ma. para estas bacias tardias. Além disso, o caráter sintectônico da sedimentação, o contato com o embasamento através de falhas rúpteis e a presença de seixos de milonito nas bacias sugerem que as zonas de cisalhamento, pelo menos em parte, atuaram em um nível crustal mais superficial nesta época.

A evolução pós-brasiliana das zonas de cisalhamento, segundo a concepção clássica, está relacionada aos estádios de transição e reativação da Plataforma SulAmericana, conforme definido por Almeida (1969). As antigas zonas de cisalhamento dúctil foram reativadas como falhas normais rúpteis, durante o Mesozóico e o Cenozóico, resultando em um sistema de riftes acompanhado por intenso magmatismo básico e alcalino, denominado Rifte Continental do Sudeste do Brasil (Riccomini et al., 2004).

\subsubsection{Estimativas de Rejeito}

Sabe-se que em cinturões transpressivos as zonas de cisalhamento comportam deslocamentos horizontais da ordem de centenas de quilômetros. Deste modo, são esperados deslocamentos semelhantes para o Sistema de Zonas de Cisalhamento da Região Sudeste do Brasil. Entretanto, são raros os trabalhos que abordam o tema, e poucas são as falhas com estimativas de rejeito (Tabela 3.1).

Hasui et al. (1975) calcularam um rejeito horizontal de $300 \mathrm{~km}$ para o sistema, a partir do deslocamento dos migmatitos da Serra de Paranapiacaba (Complexo Embu) e da Serra dos Órgãos, considerados pelos autores como correlatos.

Posteriormente, baseado no modelo de cisalhamento simples, Sadowski (1984) estima deslocamento horizontal médio de $29 \mathrm{~km}$ para a Zona de Cisalhamento Taxaquara, $50 \mathrm{~km}$ para a de Além Paraíba, e $129 \mathrm{~km}$ para a de Cubatão. Para tanto, o autor utilizou o modelo de Menard e Ranalli, que relaciona comprimento e rejeito de falhas, baseado em dados de mais de cem falhas transcorrentes conhecidas no mundo.

Campanha (1991) calculou um rejeito total de $50 \mathrm{~km}$ para a Zona de Cisalhamento Ribeira, baseado em correlações estratigráficas e na inflexão regional de estruturas. Por sua vez, Fiori (1985) estima rejeito horizontal médio de $114 \mathrm{~km}$ para a Falha da Lancinha e $106 \mathrm{~km}$ para a de Morro Agudo, através da análise do padrão de isógonas. 
Tabela 3.1. Deslocamentos horizontais calculados para zonas de cisalhamento do sudeste. (*) rejeito total.

\begin{tabular}{|l|c|c|c|l|l|}
\hline \multirow{2}{*}{$\begin{array}{c}\text { Zona de } \\
\text { cisalhamento }\end{array}$} & \multicolumn{2}{|c|}{ Deslocamento horizontal (km) } & \multicolumn{2}{|c|}{ Método } & \multicolumn{2}{|c|}{ Referência } \\
\cline { 2 - 6 } & Mínimo & Máximo & Médio & & \\
\hline \multirow{2}{*}{ Além Paraíba } & 50 & - & - & Modelo de Menard e Ranalli & Sadowski (1984) \\
\cline { 2 - 6 } & 150 & - & - & Integração da deformação & Campanha (2009) \\
\hline Cubatão & 60 & 275 & 129 & Modelo de Menard e Ranalli & Sadowski (1984) \\
\hline \multirow{2}{*}{ Lancinha } & 100 & 142 & 114 & Análise do padrão de isógonas & Fiori (1985) \\
\cline { 2 - 7 } & 150 & - & - & Integração da deformação & Campanha (2009) \\
\hline Morro Agudo & 87 & 122 & 106 & Análise do padrão de isógonas & Fiori (1985) \\
\hline \multirow{2}{*}{ Ribeira } & - & - & $50^{*}$ & Inflexão regional de estrutura & Campanha (1991) \\
\cline { 2 - 7 } & 70 & - & - & Integração da deformação & Campanha (2009) \\
\hline \multirow{2}{*}{ Taxaquara } & 14 & 62 & 29 & Modelo de Menard e Ranalli & Sadowski (1984) \\
\cline { 2 - 6 } & 100 & - & - & Integração da deformação & Campanha (2009) \\
\hline \multirow{2}{*}{ Todo o Sistema } & - & - & $300^{*}$ & Inflexão regional de estrutura & Hasui et al. (1975) \\
\cline { 2 - 6 } & $600^{*}$ & - & - & Integração da deformação & Campanha (2009) \\
\hline
\end{tabular}

Recentemente, Campanha (2009) estimou deslocamentos dúcteis mínimos da ordem de $150 \mathrm{~km}$ para as zonas de cisalhamento Lancinha e Além Paraíba, e de 100 e 70 km, para as zonas de cisalhamento Taxaquara e Ribeira, respectivamente. Tais cálculos se basearam na técnica de integração da deformação em zonas de cisalhamento, levando em conta as estruturas rotacionadas, dobras escalonadas e elipsóides de deformação, bem como a correlação de níveis estratigráficos. A somatória dos deslocamentos ao longo do Sistema de Zonas de Cisalhamento do Sudeste é de, no mínimo, $600 \mathrm{~km}$. 


\section{GeOlogia LoCAL}

Durante os trabalhos de campo, constatou-se a predominância de dois litotipos fundamentais na área de estudos: mica xistos e granitóides, como constatado por Coutinho (1972). Estes últimos apresentam composições e texturas variadas, compondo o extenso corpo magmático denominado Batólito Agudos Grandes. Os metapelitos situados a sul da Zona de Cisalhamento Caucaia são classicamente referidos como pertencentes ao Complexo Embu (Hasui, 1975a; Hasui e Sadowski, 1976). Porém, também são observados e documentados xistos a norte da ZCC, que foram classificados como pertencentes ao Grupo Votuverava na Carta Geológica do Brasil ao Milionésimo (BRASIL, 2004).

Por outro lado, o Mapa Geológico de São Paulo, em escala 1:250.000 (BRASIL, 1999), considera os metapelitos ainda como Complexo Embu, como estabelecido pelos trabalhos de Hasui (1975a) e Hasui e Sadowski (1976). Esta última concepção foi adotada neste trabalho, pois não foram observadas diferenças substanciais (em escala de afloramento e em lâminas) entre os metassedimentos a norte e a sul da Zona de Cisalhamento Caucaia. Entretanto, a pequena quantidade de dados coletados não permite discutir o assunto de maneira mais aprofundada.

\subsection{Complexo Embu}

O Complexo Embu foi definido por Hasui (1975a), em seu trabalho sobre a geologia da folha São Roque, em escala 1:100.000, sendo composto essencialmente por migmatitos. Os migmatitos do Complexo Embu são dominados pelo paleossoma, representado por gnaisse, mica xisto e quartzo xisto, cujas associações minerais são compatíveis com metamorfismo em fácies anfibolito. $\mathrm{O}$ neossoma apresenta granulação variável e composição variando de granítica a granodiorítica.

Segundo o mesmo autor, a estrutura dominante nos migmatitos é estromatítica ou acamadada, caracterizada por neossoma formando faixas concordantes com a xistosidade do paleossoma. Subordinadamente ocorrem termos oftálmicos/ocelares definidos por neossoma disperso no paleossoma, formando "olhos" constituídos por fenocristais de feldspato. Localmente, também ocorre estrutura flebítica caracterizada por paleossoma intensamente recortado por veios irregulares de neossoma, dando aspecto venoso à rocha.

No campo, tem-se a impressão de que, na realidade, as rochas descritas anteriormente não corresponderiam a migmatitos strictu sensu, ou seja, não seriam 
oriundas de fusão parcial in situ, como também sugeriram Fernandes et al. (1990), estudando o Complexo Embu a sul da Bacia de Taubaté. Aventa-se a possibilidade destas rochas serem xistos intrudidos por camadas, veios e bolsões de granitóides, dada a proximidade e ocorrência generalizada de magmatitos pertencentes ao Batólito Agudos Grandes na área estudada. Tal hipótese é reforçada por Janasi et al. (1990), que afirmam que vários granitóides (granitos Ibiúna, Itapevi e Piedade) ocorrem tipicamente como intrusões laminares, intercaladas com expressivos volumes de rocha encaixante.

Seguindo esta linha de raciocínio, foram observados xistos, quartzo xistos e gnaisses associados ao Complexo Embu. Os xistos são compostos predominantemente por biotita, muscovita e quartzo em diferentes proporções. Minerais opacos, zircão, turmalina, granada, hornblenda, clorita, titanita, epídoto, oligoclásio e microclínio ocorrem como acessórios. Os gnaisses apresentam mineralogia semelhante, porém, podem atingir $25 \%$ ou mais de oligoclásio. Tal mineralogia é compatível com metamorfismo em fácies anfibolito.

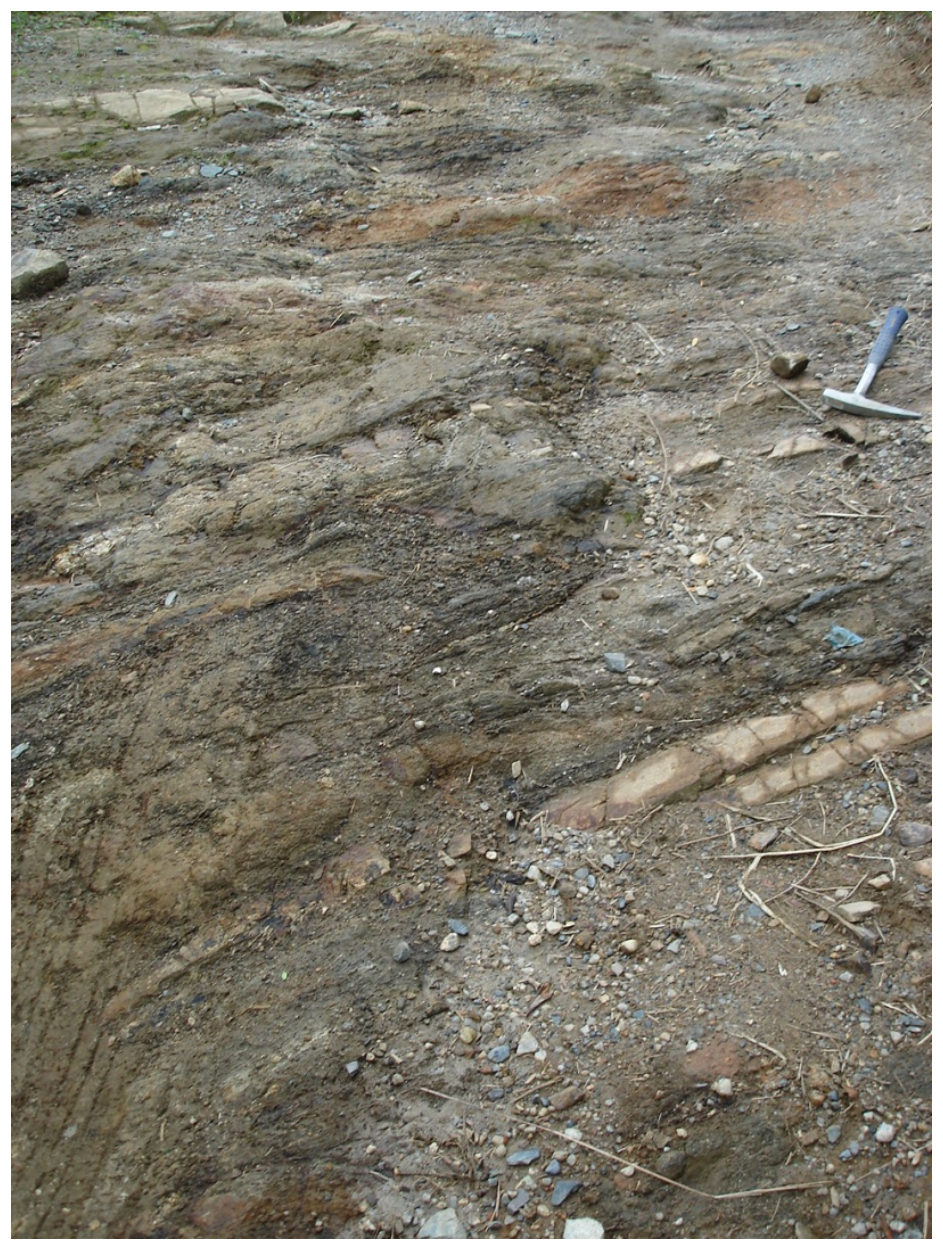

Figura 4.1. Aspecto geral do muscovita-quartzo-biotita xisto intercalado com camadas de granito róseo, pertencente ao Complexo Embu. 
Os xistos apresentam granulação média a grossa e coloração cinza a preta, quando os metassedimentos são frescos, e vermelha, quando intemperizados. Nestes litotipos é comum a ocorrência de intercalações de quartzito, quartzito cálcio-silicático, granitóides (Figura 4.1), e possíveis restitos, formando concentrações locais de biotitas grandes e bem recristalizadas com aspecto deformado.

Os granitóides intercalados apresentam composição granítica a granodiorítica, e granulação média a grossa, formando faixas, bolsões e lentes. Quartzo, microclínio pertítico e oligoclásio ocorrem como minerais essenciais, e biotita, muscovita, titanita, clorita, opacos, allanita e zircão como acessórios.

As intercalações cálcio-silicáticas apresentam granulação média a fina, e composição dada por quartzo, epídoto, plagioclásio, muscovita, granada, e raros biotita, zircão, opacos, apatita, clorita, titanita e microclínio.

Os xistos do Complexo Embu exibem foliação bem marcada, dada por bandas de muscovita e biotita fortemente orientadas e de quartzo. Os metapelitos apresentam-se localmente crenulados e dobrados, exibindo dobras abertas e dobras intrafoliais (Figura 4.2) realçada por um nível quartzo-feldspático.

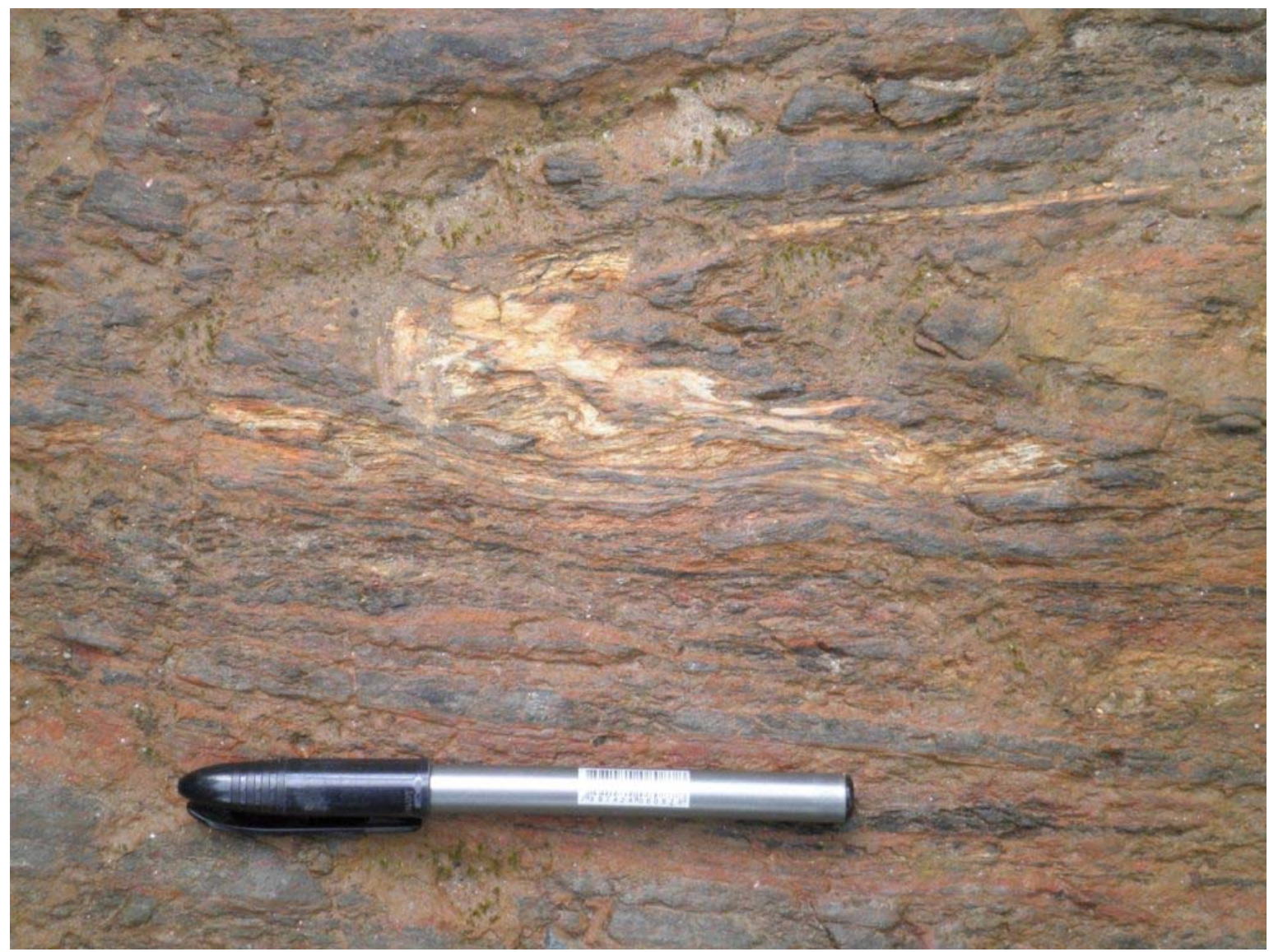

Figura 4.2. Muscovita-biotita xisto portando nível quartzo-feldspático exibindo dobra intrafolial. 
Ao microscópio óptico, classifica-se a foliação como espaçada, disjuntiva, aproximadamente paralela e gradacional. Algumas amostras apresentam muscovitas e biotitas dobradas e com extinção ondulante (Figura 4.3), indicando deformação intracristalina nos filossilicatos. Além disso, foram observados porfiroblastos de muscovita portando inclusões de quartzo.

Constatou-se também que os xistos do Complexo Embu ocorrem predominantemente a sudeste da Zona de Cisalhamento Caucaia. Porém, o litotipo em questão também aparece a noroeste da estrutura, como corpos restritos (poucos $\mathrm{km}$ de raio), em meio aos granitóides do Batólito Agudos Grandes, como observado por Hasui (1975b) na região de Ibiúna.

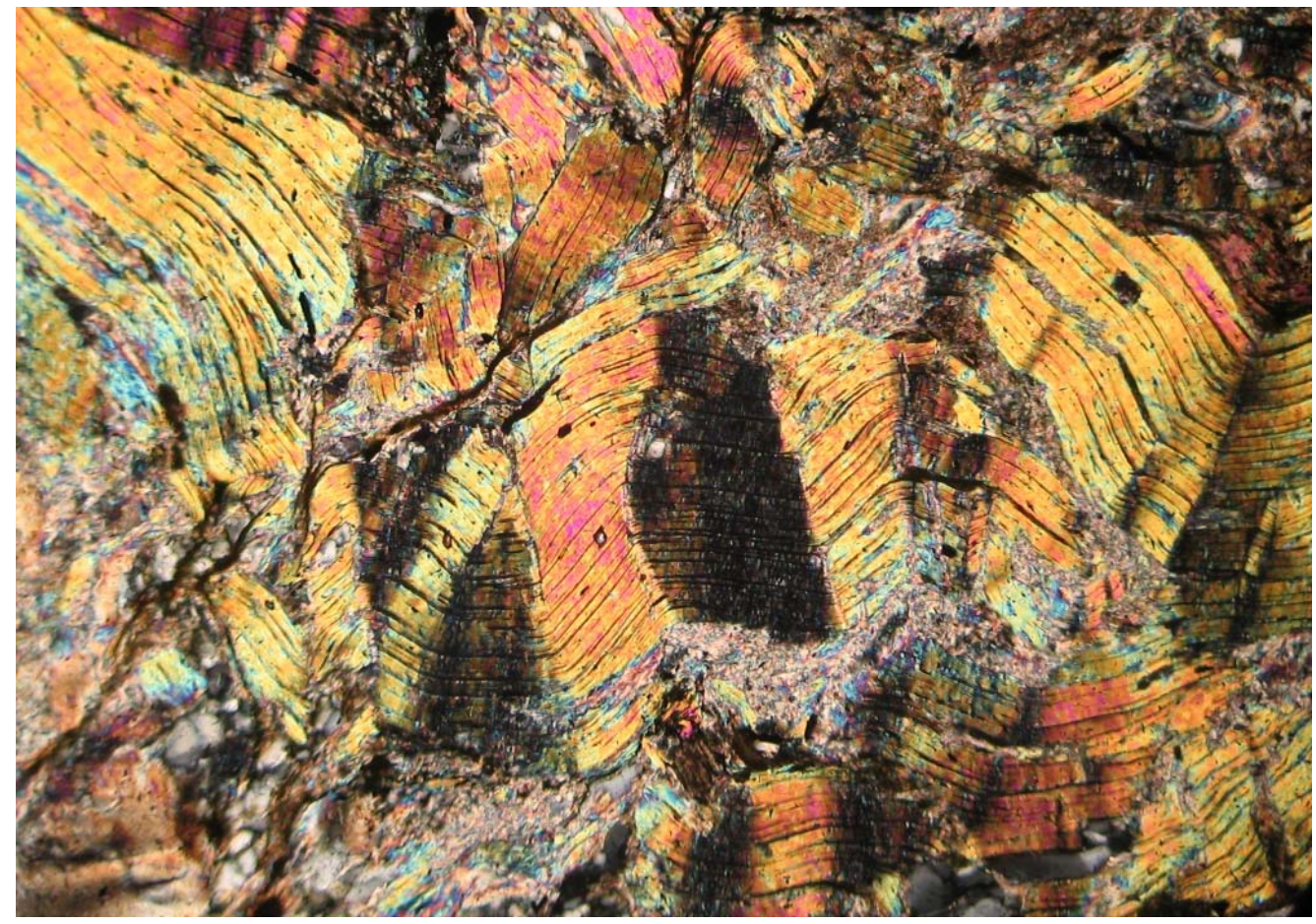

Figura 4.3. Fotomicrografia de muscovita xisto do Complexo Embu, mostrando muscovitas dobradas e com extinção ondulante.

\subsection{Batólito Agudos Grandes}

Uma das características de destaque da geologia da área estudada corresponde à quantidade expressiva de corpos graníticos intrudidos nos metamorfitos do Complexo Embu. Hasui (1975a) estima que os granitóides perfaçam 3/4 da área abrangida pela folha São Roque (em escala 1:100.000).

No campo, verifica-se o predomínio de granodiorito porfirítico, com fenocristais róseos de microclíneo e cinzentos de oligoclásio, com dimensões de até 2-3x6-7 cm. Este litotipo se destaca pelo contraste de cores e/ou pelos megacristais formarem protuberâncias 
na superfície, sã ou alterada, de matacões e lajedos. Daí existirem denominações informais como granito Varejão ou "olho-de-sapo" (Hasui, 1975a).

Posteriormente, com a realização de trabalhos de mapeamento de maior detalhe, verificou-se que os granitóides a oeste da capital paulista constituem um conjunto extenso, alongado segundo a direção NE-SW, com aproximadamente $240 \mathrm{~km}$ e largura variando de 20 a $70 \mathrm{~km}$. Este conjunto é denominado Batólito Agudos Grandes, e juntamente com os batólitos alongados de Pinhal-Ipuiúna, Socorro e Três Córregos, constitui uma feição marcante da geologia do estado de São Paulo (Janasi et al., 1990).

Os mesmos autores mapearam a porção leste do Batólito Agudos Grandes em escala de reconhecimento (1:250.000), e definiram os diferentes fácies petrográficos baseados em critérios estruturais, mineralógicos e texturais. Assim, foi sugerida a seguinte divisão:

- granitóides sin-orogênicos brasilianos - de idade estimada em ca. 650 Ma., englobam magmatitos de cinco fácies distintos, agrupados informalmente em "tipos": Ibiúna (biotita-hornblenda granodiorito a monzogranito porfirítico), Tapiraí (biotita monzogranito a quartzo monzonito porfirítico), Itapevi (biotita monzogranito, equi- a inequigranular), de associação cálcio-alcalina amplamente dominante, além dos tipos Piedade (biotita-muscovita monzogranito, subdividido em três fácies) e Turvo (biotitamuscovita monzogranito, equi- a inequigranular) de afinidade marginal a francamente peraluminosa.

- granitóides tardi a pós-orogênicos - de idade estimada em ca. 600 Ma., estão relacionados com o Cinturão Granítico Itu, sendo agrupados em dois "tipos": Pilar do Sul (muscovita-biotita monzogranito, porfirítico a equigranular) e Serra da Bateia (biotita sienogranito porfirítico) de afinidade cálcio-alcalina.

Trabalhos posteriores (Janasi et al., 2001; Leite et al., 2007), envolvendo mapeamento faciológico em escala de detalhe e aplicação de métodos geocronológicos, possibilitaram o refinamento do modelo evolutivo do Batólito Agudos Grandes. Assim, foram caracterizados três pulsos magmáticos distintos:

- Magmatismo sin-orogênico_ composto predominantemente por hornblenda-biotita quartzo monzonito a monzogranito, megaporfirítico, metaluminosos, de caráter cálcioalcalino de alto potássio, equivalente ao tipo Ibiúna de (Janasi et al., 1990). Idades U-Pb em zircões indicam pico de produção de granitos no período de 615 a 605 Ma. (Janasi et al., 2001). Há evidências de que o magmatismo já tivesse se iniciado em 625 Ma. 
(Prazeres Filho et al., 2003). Neste contexto, se inserem os granitos Ibiúna, Tapiraí, Itapevi, Caucaia e Turvo.

- Magmatismo tardi-orogênico_predominam granitos cálcio-alcalinos contaminados, que variam de biotita( \pm muscovita) granito a granodiorito porfirítico (Granito Piedade) a muscovita-biotita leucogranito equigranular (Granito Pilar do Sul). A idade de colocação é estimada entre 600 e $605 \mathrm{Ma}$. (método U-Pb em zircão e monazita). Neste contexto, são incluídos os granitos Piedade (que antes das datações era considerado como sinorogênico), Pilar do Sul, Serra dos Lopes e Roseira.

- Magmatismo pós-orogênico_correspondem a granitos tipo A, subdivididos em dois grupos: (1) hornblenda-biotita monzogranito porfirítico (Granito São Miguel Arcanjo) e biotita sienogranito equigranular (Granito Capão Bonito), cuja idade é estimada em 585 Ma. e relacionados com a Província Granítica Itu, que se desenvolveram após o final dos eventos compressivos principais; (2) biotita sienogranito a monzogranito porfirítico, relacionado a um segundo evento mais jovem que o anterior, de idade estimada em 565 Ma., e que engloba os granitos Serra da Bateia e Serra da Queimada.

Nos trabalhos de campo, foram observados e descritos afloramentos de três tipos de granitos relacionados ao magmatismo sin-orogênico:

Granito Ibiúna - Corresponde a um hornblenda-biotita granodiorito a monzogranito porfirítico (Prancha 1-A), com megacristais róseos de microclínio pertítico, subretangulares de dimensões 1-2x4-5 cm. A matriz é inequigranular, de granulação média a grossa e cor cinza. A análise petrográfica mostra que os minerais essenciais são quartzo, microclínio, plagioclásio, biotita e hornblenda; como acessórios foram observados titanita, allanita, clorita, epídoto, zircão e minerais opacos. Foram observados enclaves microgranulares escuros e pequenos corpos dioríticos, como descrito por (Janasi et al., 1990).

Granito Caucaia - É caracterizado como um biotita granito equi- a inequigranular, médio, e coloração cinza (Prancha 1-B). Ao microscópio óptico verificou-se que o quartzo, microclínio, plagioclásio e biotita são os minerais essenciais. Além deles, ocorre hornblenda, muscovita, epídoto, titanita, zircão e opacos como minerais acessórios.

Granito Tapiraí - Ocorre como um biotita monzogranito a quartzo monzonito porfirítico (Prancha 1-C), cuja matriz é equigranular média e coloração cinza clara. Os megacristais são formados por microclínio, retangular a sub-retangular, de dimensões $1 \times 3-4 \mathrm{~cm}$. $\mathrm{O}$ 
granito Tapiraí difere do granito Ibiúna pelo menor tamanho dos megacristais, menor índice de cor e pela ocorrência esporádica de hornblenda.
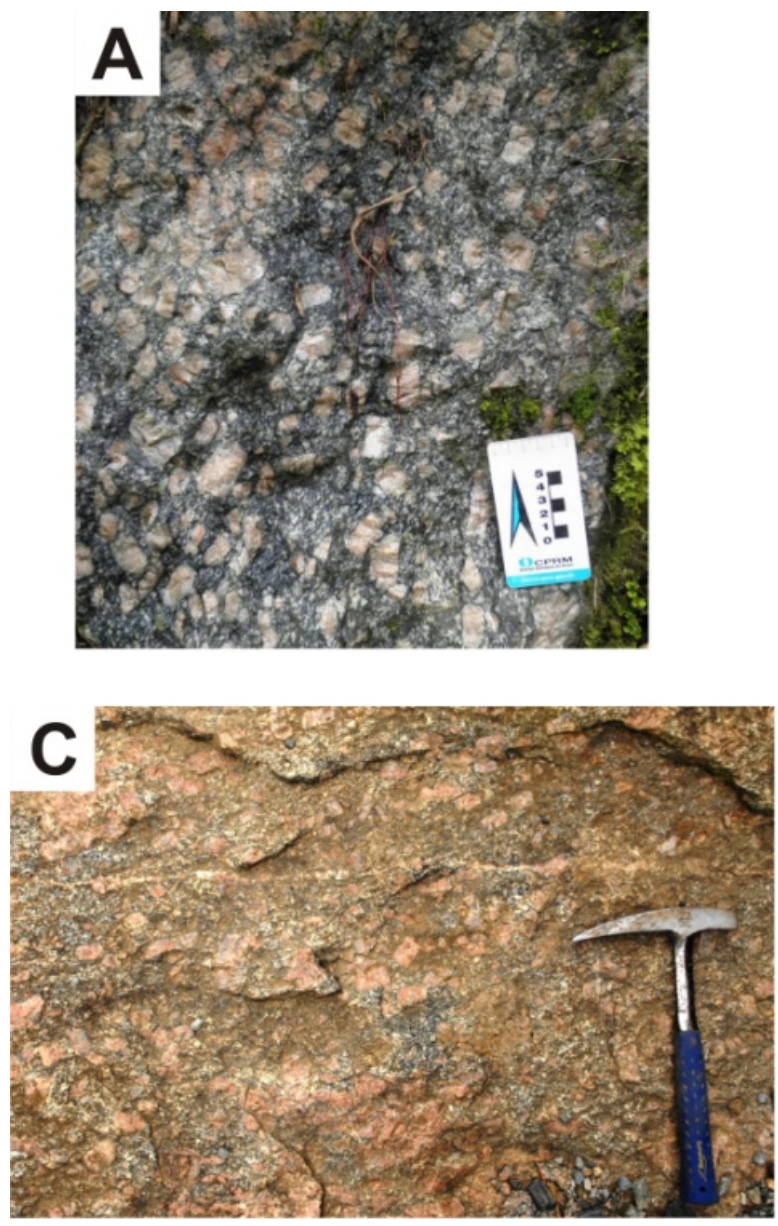
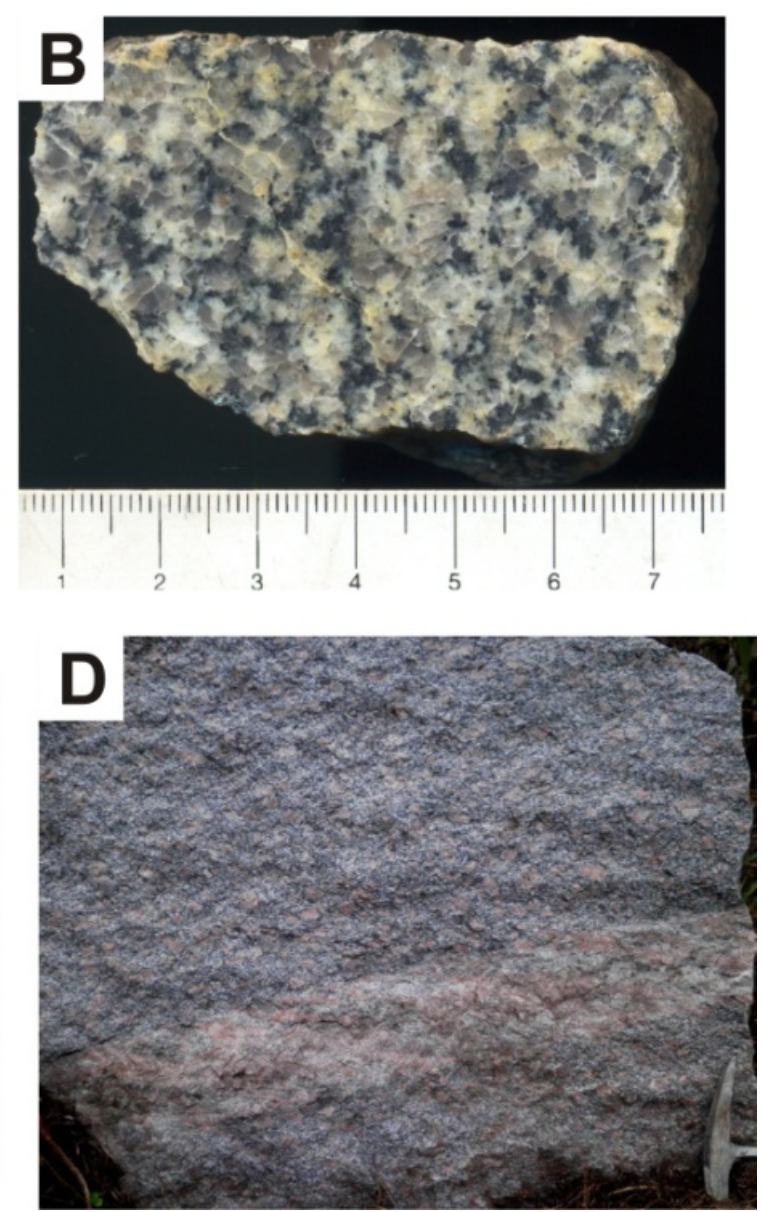

Prancha 1. Aspecto geral de: (A) Granito Ibiúna - hornblenda-biotita monzogranito porfirítico; (B) Granito Caucaia - biotita granito equigranular; (C) Granito Tapiraí - hornblenda-biotita monzogranito porfirítico; e (D) Granito Ibiúna - hornblenda-biotita granodiorito porfirítico.

Indícios de deformação são comumente vistos ao se analisar seções delgadas dos granitos. Podem ser citados: lamelas de geminação localmente dobradas em feldspatos, extinção ondulante em quartzo (matriz) e feldspato (megacristais), micas dobradas e exibindo extinção ondulante, entre outras feições. Ao se aproximar da Zona de Cisalhamento Caucaia, a deformação registrada aumenta drasticamente. Assim, verifica-se a produção de lamelas de deformação, bem como fraturamento e rotação dos feldspatos, recristalização dinâmica do quartzo, entre outras microestruturas indicativas de deformação mais intensa. Algumas destas feições microestruturais foram descritas por Hasui (1975a) e atribuídas a processos de cataclase, como era o pensamento em voga na época, posterior à formação das rochas magmáticas. 


\section{ANÁliSe ESTRUTURAL}

A Zona de Cisalhamento Caucaia está inserida no Sistema de Zonas de Cisalhamento do Sudeste do Brasil. É tida como uma estrutura regional importante, uma vez que limita os terrenos Apiaí e Embu, respectivamente, a leste e a oeste.

A seguir, a zona de cisalhamento será descrita com relação à sua geometria, metamorfismo e cinemática, envolvendo aspectos microestruturais, indicadores de sentido de movimentação, trama cristalográfica do quartzo e vorticidade.

\subsection{Aspectos geométricos}

A Zona de Cisalhamento Caucaia (ZCC) estende-se por $242 \mathrm{~km}$, aflorando desde a borda sudoeste da Bacia Sedimentar de São Paulo, terminando na Zona de Cisalhamento Lancinha-Cubatão. Deste total, foram estudados $123 \mathrm{~km}$ de extensão, referentes à metade nordeste da zona de cisalhamento. Neste trecho a espessura da faixa de rochas deformadas atribuída à ZCC varia desde alguns metros até aproximadamente um quilômetro.

A zona de cisalhamento apresenta forma ligeiramente sinuosa, com orientação geral NE-SW, infletindo para E-W pouco a sul da cidade de Tapiraí, definindo assim dois segmentos. Entretanto, observações de campo sugerem que o ramo NE-SW da Zona de Cisalhamento Caucaia persiste, mesmo após a "inflexão", como mostrado no mapa geológico (Figura 5.1).

Constatou-se que a deformação associada à ZCC é eminentemente dúctil, com a formação de rochas miloníticas (protomilonitos, milonitos e ultramilonitos), desenvolvidas preferencialmente sobre biotita granito equigranular (Granito Caucaia), hornblenda-biotita granodiorito a monzogranito porfirítico (Granito Ibiúna) e biotita monzogranito porfírítico (Granito Tapiraí) pertencentes ao Batólito Agudos Grandes. Nos granada-biotita-muscovita xistos e biotita-quartzo-muscovita xistos pertencentes ao Complexo Embu a deformação se processa através de movimentação preferencial paralela aos planos de orientação das micas. Nestes, a deformação é visível somente quando o feldspato está presente, formando porfiroclastos rotacionados em meio à matriz predominantemente micácea. 


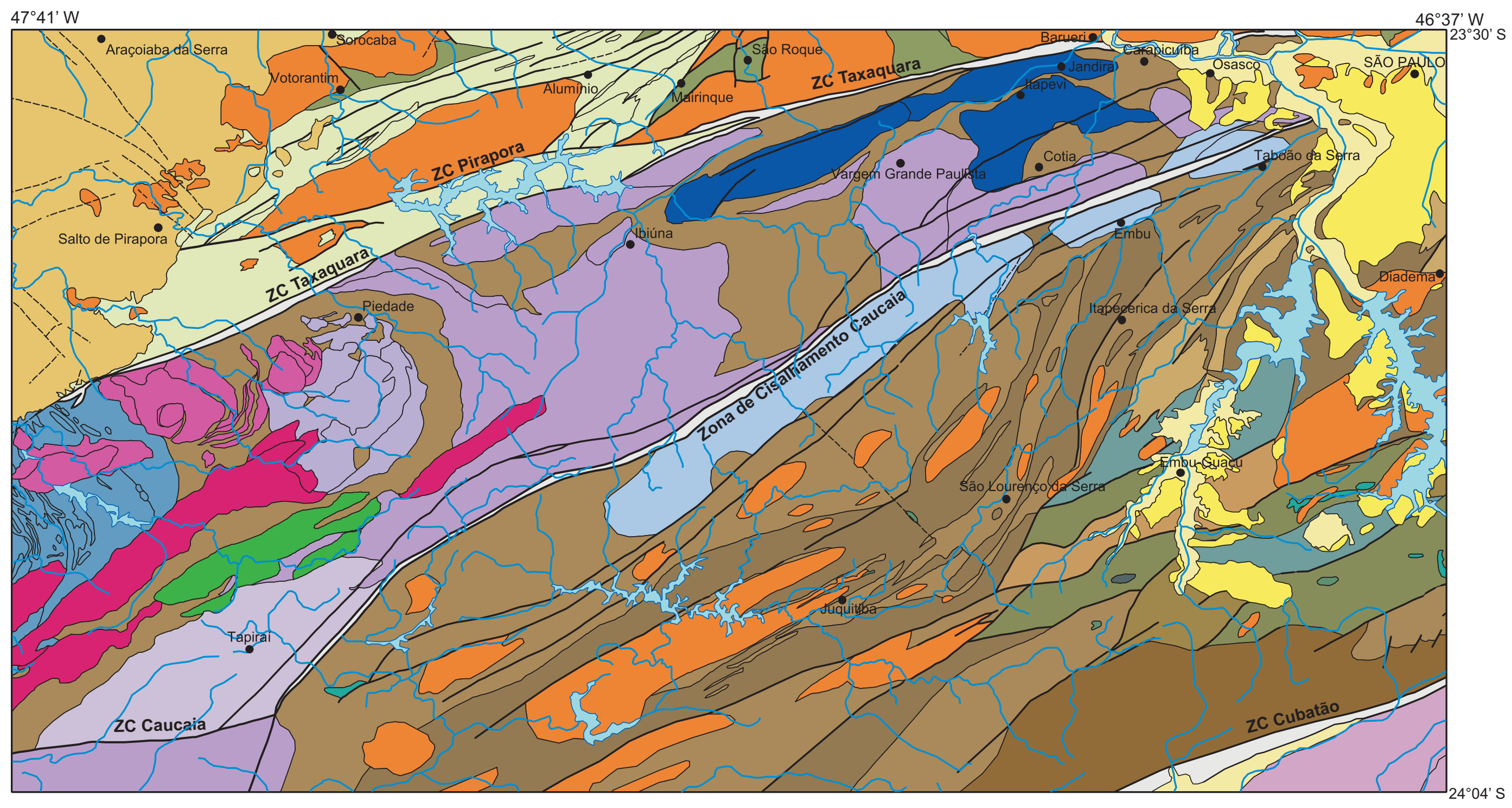

Figura 5.1. Mapa geológico simplificado da área estudada. Modificado de BRASIL (1999, 2004), Leite et al. (2007), e Janasi et al. (inédito). 0 


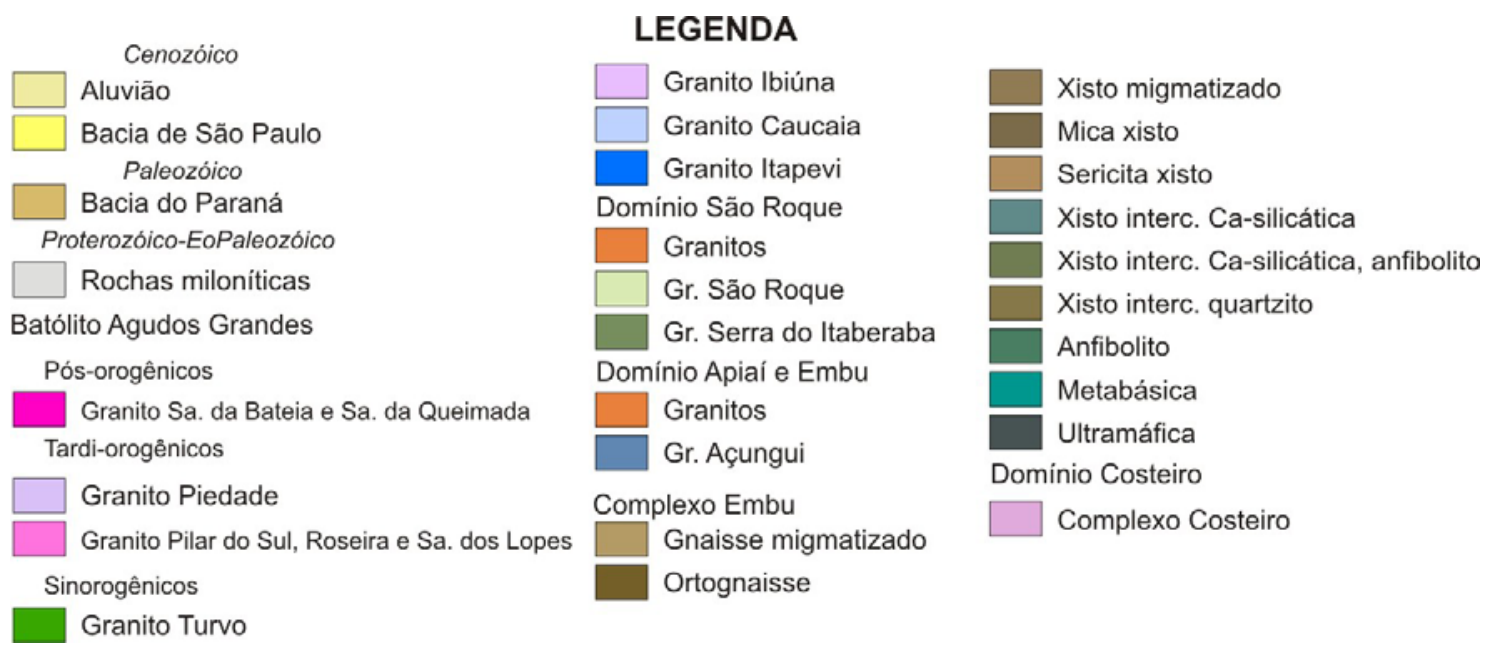

Figura 5.1. Unidades geológicas consideradas na área estudada.
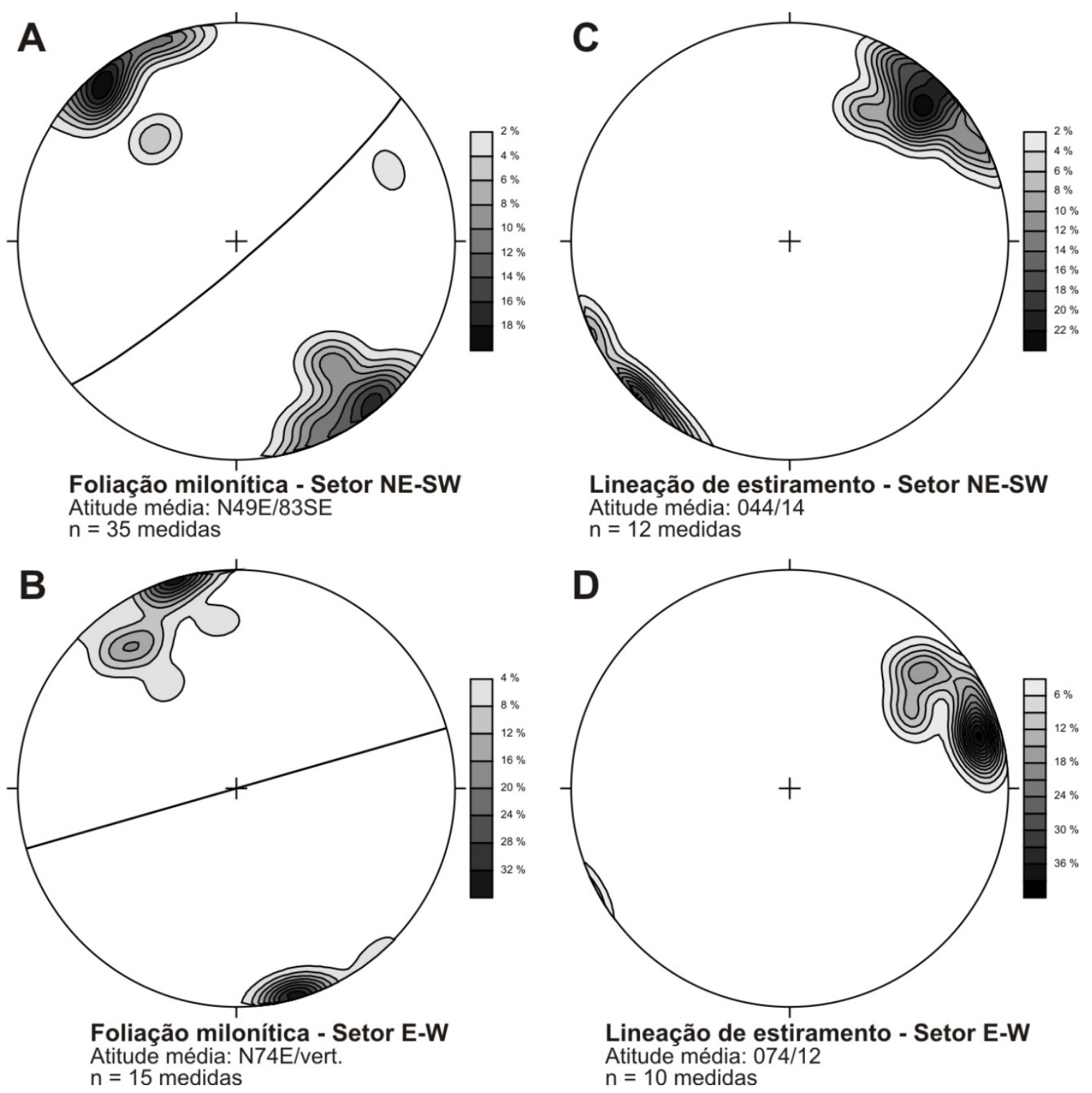

Figura 5.2. Estereogramas da foliação milonítica para os setores NE-SW (A) e E-W (B), e da lineação de estiramento para os mesmos setores, respectivamente (C) e (D). Rede de SchmidtLambert, hemisfério inferior. 
A Zona de Cisalhamento Caucaia é marcada por foliação milonítica com orientação média N49E, mergulhando $83^{\circ}$ para a SE, em seu segmento principal. Ao sul da cidade de Tapiraí, representando o segmento E-W da ZCC, a foliação milonítica apresenta direção média N74E, com mergulho vertical. Além disso, observou-se em campo uma forte lineação de estiramento de baixo ângulo, de orientação média 044/14 e 074/12, respectivamente para os setores NE-SW e E-W da zona de cisalhamento (Figura 5.2).

A

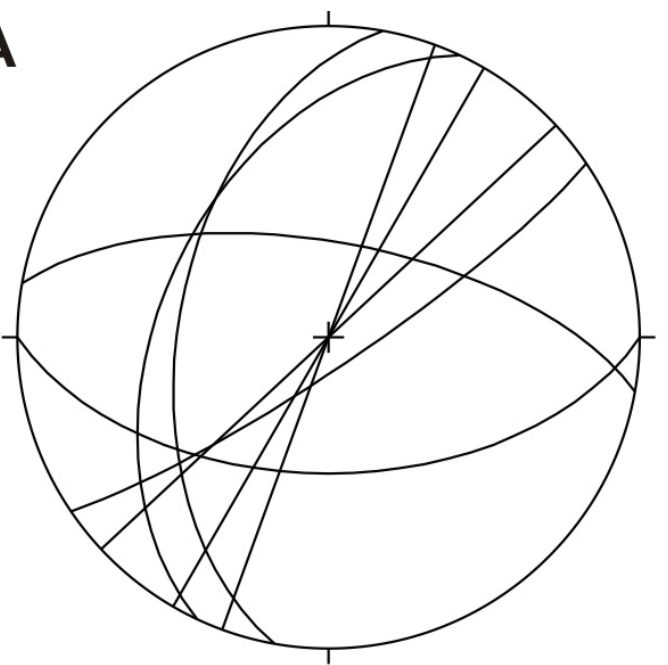

Batólito Agudos Grandes (Domínio N)

Foliação de fluxo magmático

$\mathrm{n}=8$ medidas

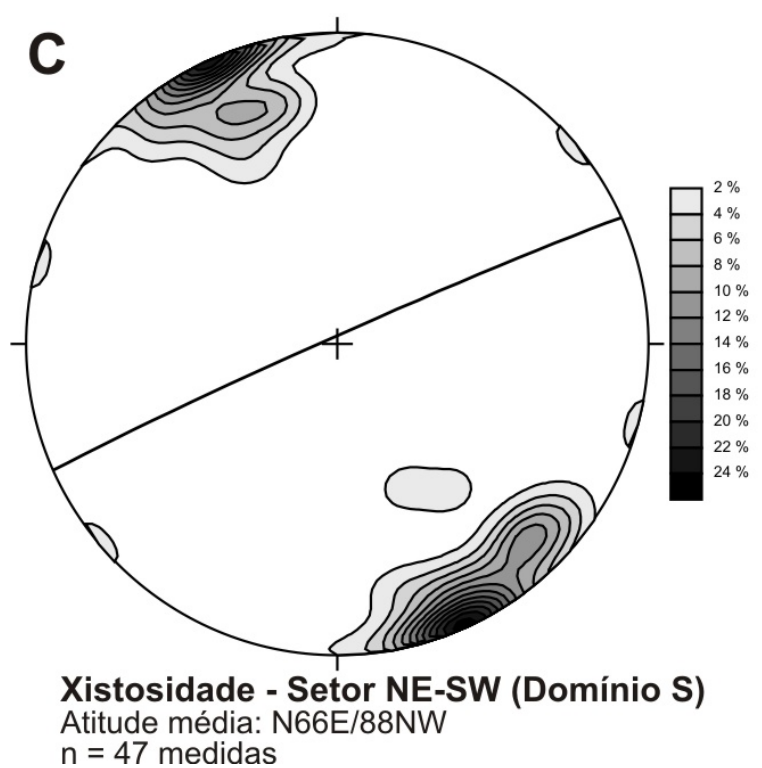

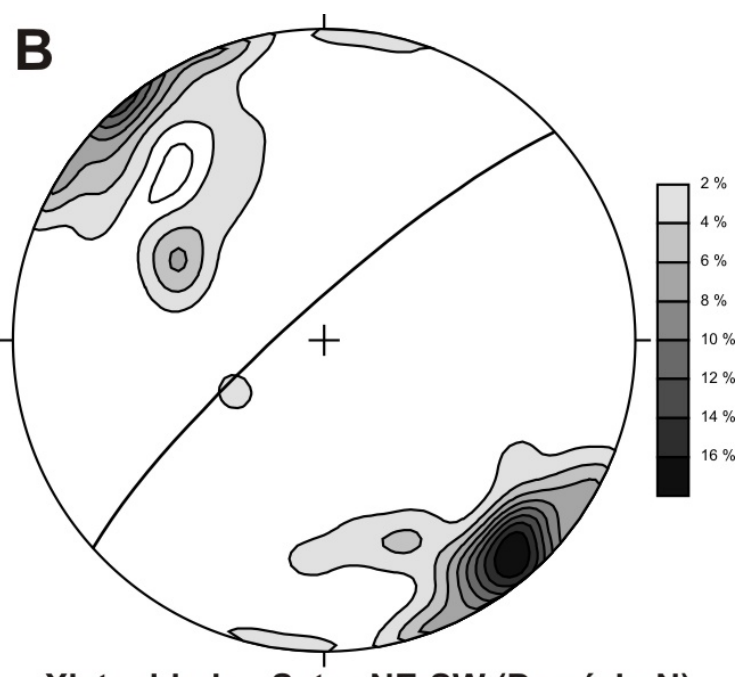

Xistosidade - Setor NE-SW (Domínio N) Atitude média: N48E/81NW $\mathrm{n}=49$ medidas

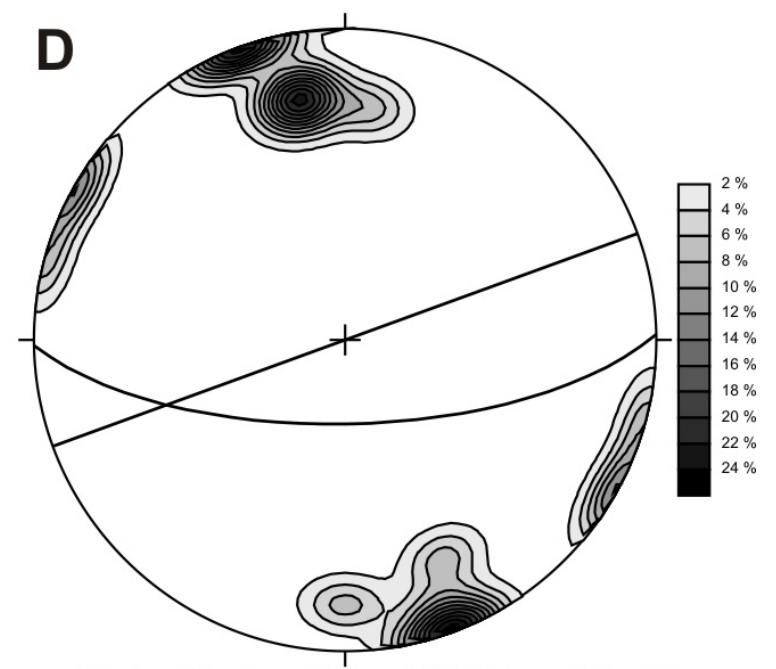

Xistosidade - Setor E-W (Domínio S) Atitudes: N64E/vert. (princ.) e EW/68S (sec.) $\mathrm{n}=16$ medidas

Figura 5.3. Estereogramas de: foliação de fluxo magmático do Batólito Agudos Grandes (A); xistosidade do Complexo Embu, setor NE-SW domínio a norte (B) e a sul da zona de cisalhamento (C); e xistosidade do setor E-W, domínio a sul da Zona de Cisalhamento Caucaia. Rede de Schmidt-Lambert, hemisfério inferior. 


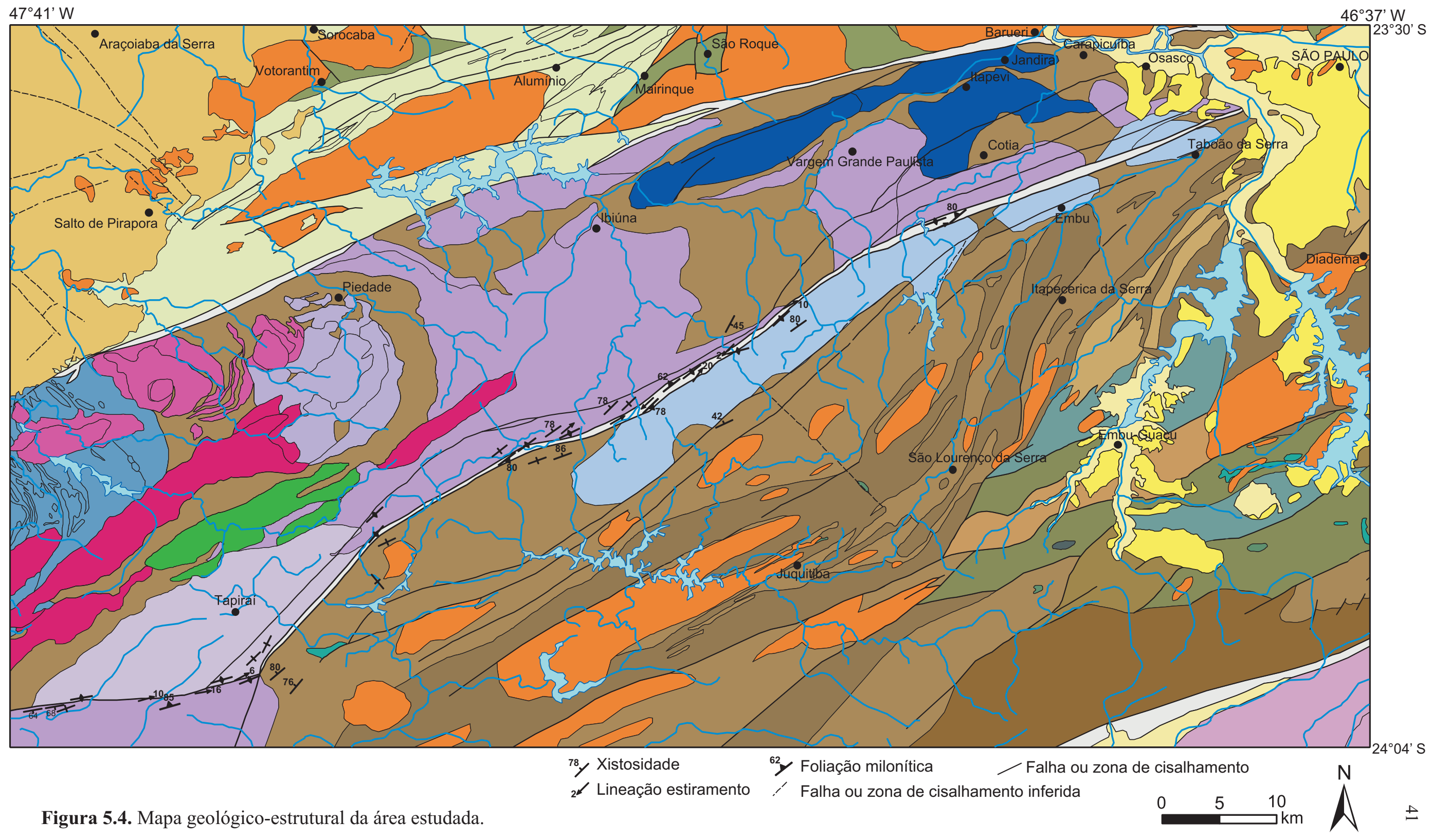


Os dados acima indicam que a Zona de Cisalhamento Caucaia é uma zona de cisalhamento direcional a oblíqua, com componente direcional (transcorrente) de caráter destral e componente de mergulho com bloco alto a sudeste desta estrutura.

No campo, observou-se que o Granito Ibiúna apresenta, localmente, uma foliação, incipiente a marcada, caracterizada pela orientação preferencial do quartzo e da biotita, bem como pelo alinhamento de parte dos fenocristais de microclínio pertítico. Esta foliação foi inferida como decorrente de fluxo magmático e que, a despeito da pequena quantidade de medidas, apresenta orientação variável (Figura 5.3A).

Os xistos do Complexo Embu apresentam foliação bem marcada, dada pela orientação preferencial segundo bandas micáceas (biotita e muscovita) e de quartzo. Analisando os dados de campo, verifica-se que a xistosidade apresenta orientação média segundo a direção $\mathrm{N} 48 \mathrm{E}$, mergulhando $81^{\circ}$ para $\mathrm{NW}$, no setor a norte da ZCC, e segundo a direção N66E, com mergulho vertical, para a porção a sul da zona de cisalhamento (Figura 5.4). Por sua vez, no segmento E-W, a sul da ZCC, a xistosidade tem atitude média N64E, com mergulho vertical. Há também um máximo secundário de orientação E-W, mergulhando $68^{\circ}$ para sul (Figura 5.3B-D).

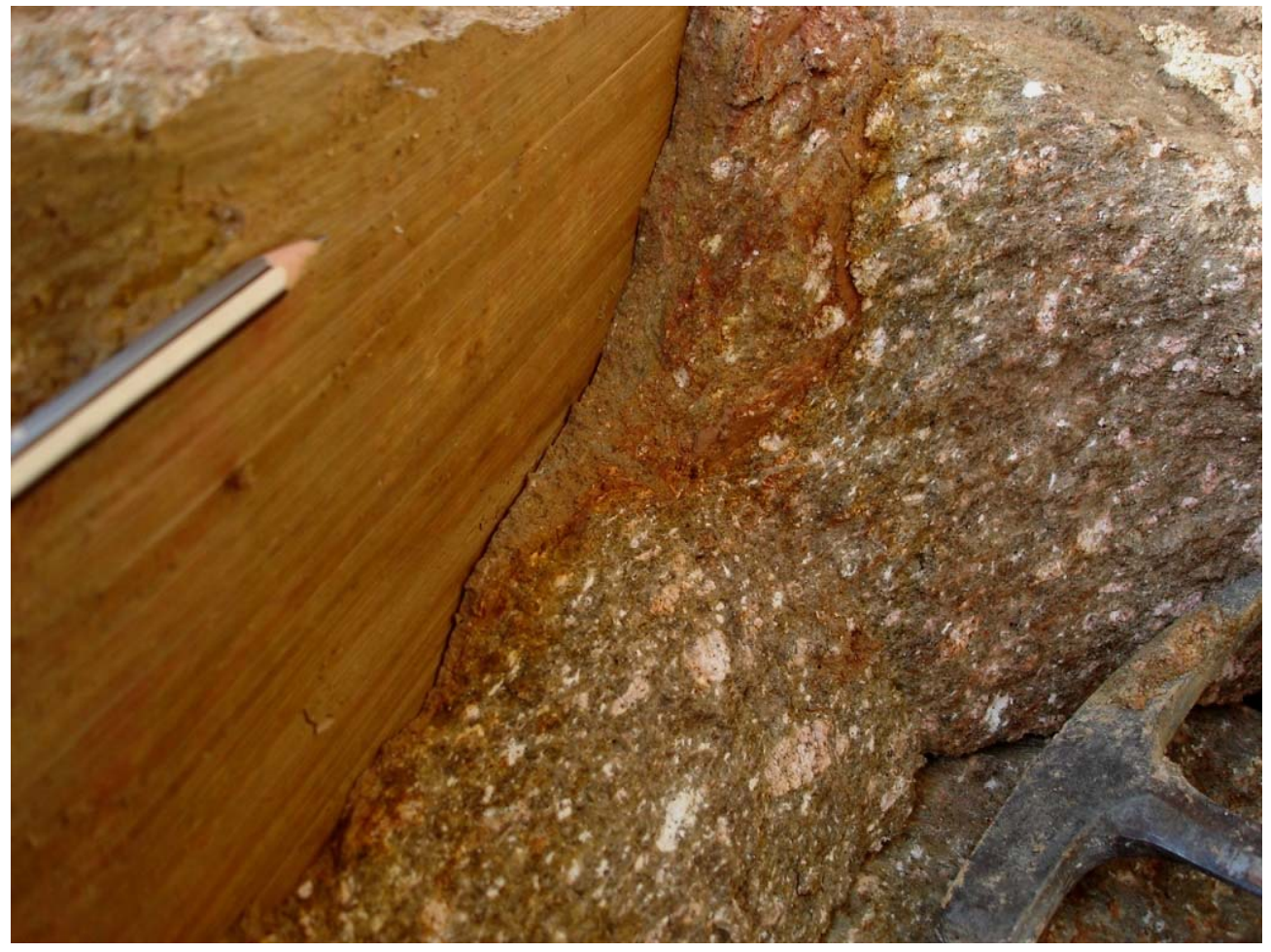

Figura 5.5. Espelho de falha e estria de atrito em biotita granito porfirítico milonitizado.

Outro tipo de estrutura observado em alguns afloramentos corresponde a falhas. Estas estruturas rúpteis seccionam os granitos milonitizados pertencentes à ZCC (Figura 
5.5), bem como os granitóides do Batólito Agudos Grandes, nas proximidades da zona de cisalhamento.

Observando o estereograma da figura 5.6, verifica-se que a orientação das falhas é bem variável, embora predominem aquelas de atitude média N40E (direção aproximadamente paralela à ZCC), mergulhando $45^{\circ}$ para SE. Interpreta-se que estas estruturas estejam relacionadas com a exumação da zona de cisalhamento, ou com eventos posteriores, sugerindo reativação da Zona de Cisalhamento Caucaia em nível crustal mais raso.

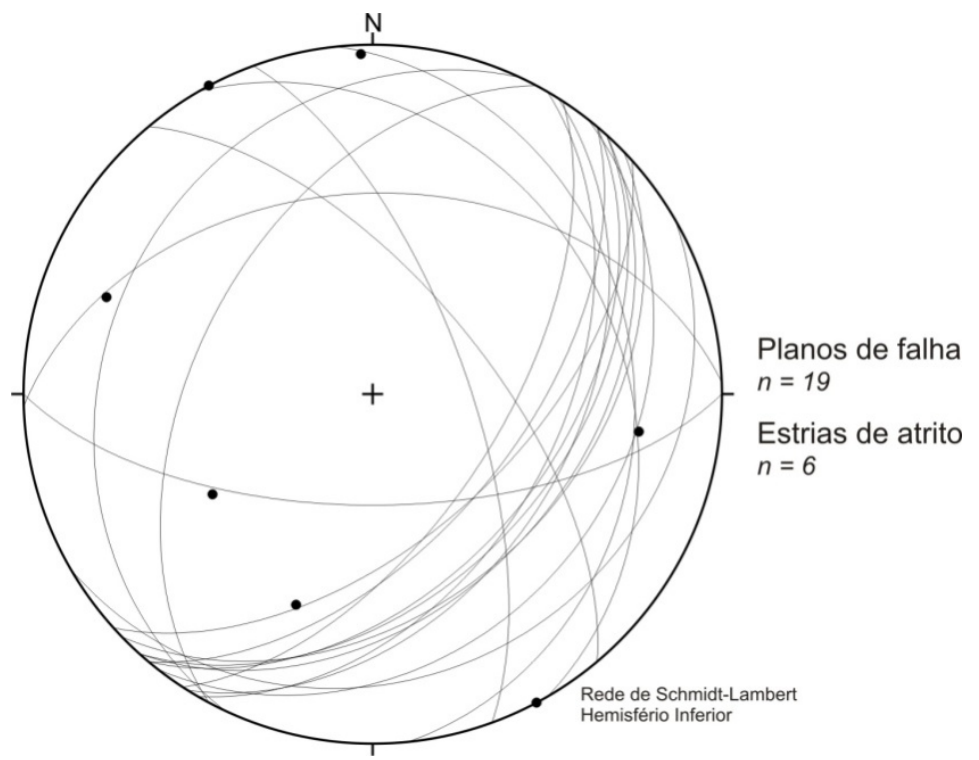

Figura 5.6. Estereograma das falhas e estrias de atrito dentro do domínio da ZCC.

\subsection{Indicadores cinemáticos mesoscópicos}

Durante a execução dos trabalhos de campo, foram observados e documentados indicadores do sentido de movimento da Zona de Cisalhamento Caucaia, em escala de afloramento. Quase todos eles indicam sentido de cisalhamento destral, e foram divididos em quatro tipos básicos: porfiroclastos manteados, estruturas S-C, boudin assimétrico, e zonas de cisalhamento secundárias.

Os porfiroclastos manteados se originaram pela deformação dos granitóides porfiríticos (granitos Ibiúna e Tapiraí) do Batólito Agudos Grandes. Assim, os antigos megacristais de microclínio pertítico foram fraturados e rotacionados em meio à matriz deformada ductilmente. Os porfiroclastos de feldspato são envoltos por um manto composto por finos grãos do mesmo mineral, formando uma cauda. O conjunto porfiroclasto-cauda pode apresentar formatos diferentes, recebendo denominações diferentes: tipos $\delta, \sigma, \varphi$, e $\theta$. A assimetria destes conjuntos, com relação à foliação 
milonítica, indica o sentido de cisalhamento. No caso estudado, foram observados porfiroclastos tipo $\sigma$ e $\delta$ (Prancha 2-A), indicando sentido de cisalhamento predominantemente destral (seis afloramentos com essa indicação, frente a um sinistral)

Estruturas S-C foram observadas na Zona de Cisalhamento Caucaia. São caracterizadas por duas foliações, que fazem ângulo moderado a baixo entre si. A foliação $\mathrm{S}$ (do termo francês schistosité) é uma trama penetrativa em todas as escalas de observação, sendo claramente produzida pelo alinhamento de grãos deformados. Por sua vez, a foliação C (do termo francês cisaillement) consiste em uma série de superfícies de cisalhamento espaçadas, marcadas por zonas de redução de granulação, e não são necessariamente penetrativas em todas as escalas de observação (Passchier e Trouw, 2005). A relação angular entre as foliações permite inferir o sentido de cisalhamento. Esse tipo de estrutura foi bem observado em três afloramentos de quartzo-biotita xisto do Complexo Embu, intercalado com camadas de biotita granito porfirítico (intrusões laminares). Nestes casos, o sentido de movimento indicado foi destral (Prancha 2-B).
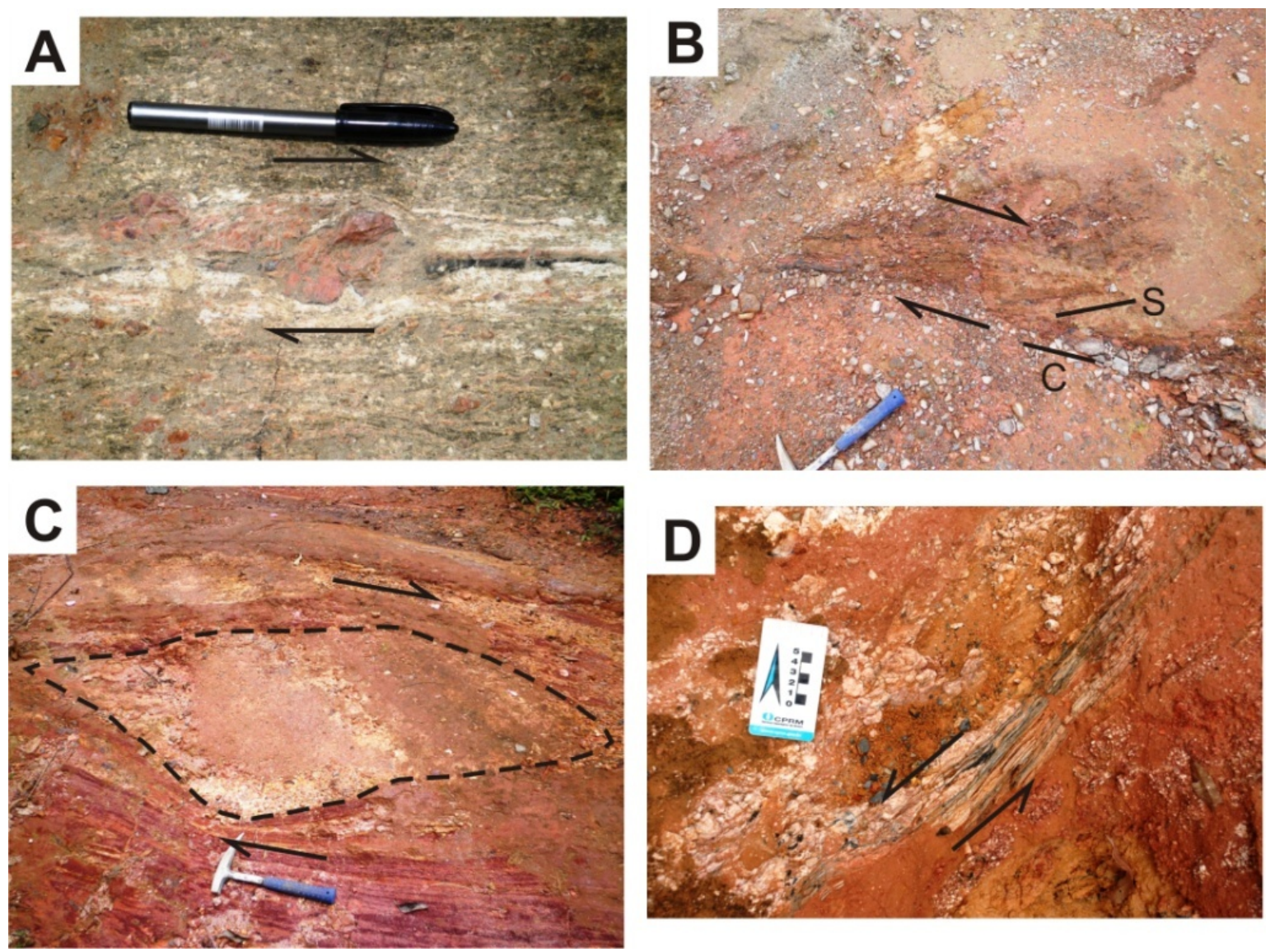

Prancha 2. Indicadores cinemáticos observados em campo: (A) porfiroclasto manteado tipo delta destral; (B) estrutura tipo S-C destral; (C) boudin assimétrico destral; e (D) pequena zona de cisalhamento secundária com fragmento de feldspato tipo delta sinistral. 
Em um afloramento de quartzo-muscovita-biotita xisto do Complexo Embu, ocorre uma pequena intrusão de muscovita granito, equigranular, médio. Este corpo ígneo apresenta-se estirado, resultando em um boudin assimétrico com formato semelhante a um megadelta (Prancha 2-C). A assimetria entre o eixo maior do boudin e a xistosidade indica sentido de movimentação destral.

Por fim, constatou-se a ocorrência de uma pequena zona de cisalhamento secundária, desenvolvida sobre biotita granito, equigranular, médio. A referida estrutura apresenta-se orientada segundo a direção N40E (aproximadamente paralela à ZCC), com aproximadamente $5 \mathrm{~cm}$ de espessura, dentro da qual, ocorrem porções feldspáticas róseas, cuja assimetria indica movimentação sinistral (Prancha 2-D).

\subsection{Petrografia e microestruturas}

A análise petrográfica e microestrutural foi realizada preferencialmente nos granitóides porfiríticos do Batólito Agudos Grandes, bem como nas porções graníticas e cálcio-silicáticas dos xistos do Complexo Embu. Isto decorre do fato da deformação associada à Zona de Cisalhamento Caucaia estar mais bem registrada nestes tipos litológicos.

Nos granitos milonitizados foram encontrados quartzo, feldspato potássico, plagioclásio e biotita como minerais essenciais. Muscovita, hornblenda, granada, clorita, epídoto, titanita, allanita, zircão, apatita e opacos ocorrem como minerais acessórios. A foliação milonítica é caracterizada por bandas quartzo-feldspáticas e micáceas orientadas. Pode ser classificada como uma foliação espaçada, tipo disjuntiva, com domínio da clivagem ondulado a suave, paralelo a anastomosado, e transição gradacional para o micróliton.

Nos milonitos verifica-se que o feldspato ocorre na matriz, como grãos de $200 \mu \mathrm{m}$ de tamanho médio. Porém, este mineral aparece preferencialmente como porfiroclastos, com dimensões variando de 1,2 a $8,0 \mathrm{~mm}$, formando microporfiroclastos, geralmente subarredondados. O feldspato potássico e o plagioclásio exibem forte deformação intracristalina incluindo extinção ondulante, lamelas de geminação localmente dobradas, lamelas de deformação (deformation twins, Prancha 3.B) e pertitas em chama (flame perthites, Prancha 3.C). Além disso, foram observados porfiroclastos fraturados (Prancha 3.A), gerando fragmentos angulosos e de dimensões variadas, alguns dos quais mostram-se rotacionados. 
O quartzo ocorre como grãos anedrais, alongados, tamanho médio de $400 \mu \mathrm{m}$, contato lobulado e extinção ondulante. No entorno destes, em geral, há pequenos grãos recristalizados, indicando recristalização dinâmica do tipo bulging (Prancha 3.D). Também foram observados domínios formados por grãos recristalizados alongados e de tamanho ligeiramente menor que os relictos, indicando recristalização por rotação de subgrão (subgrain rotation recrystallisation).
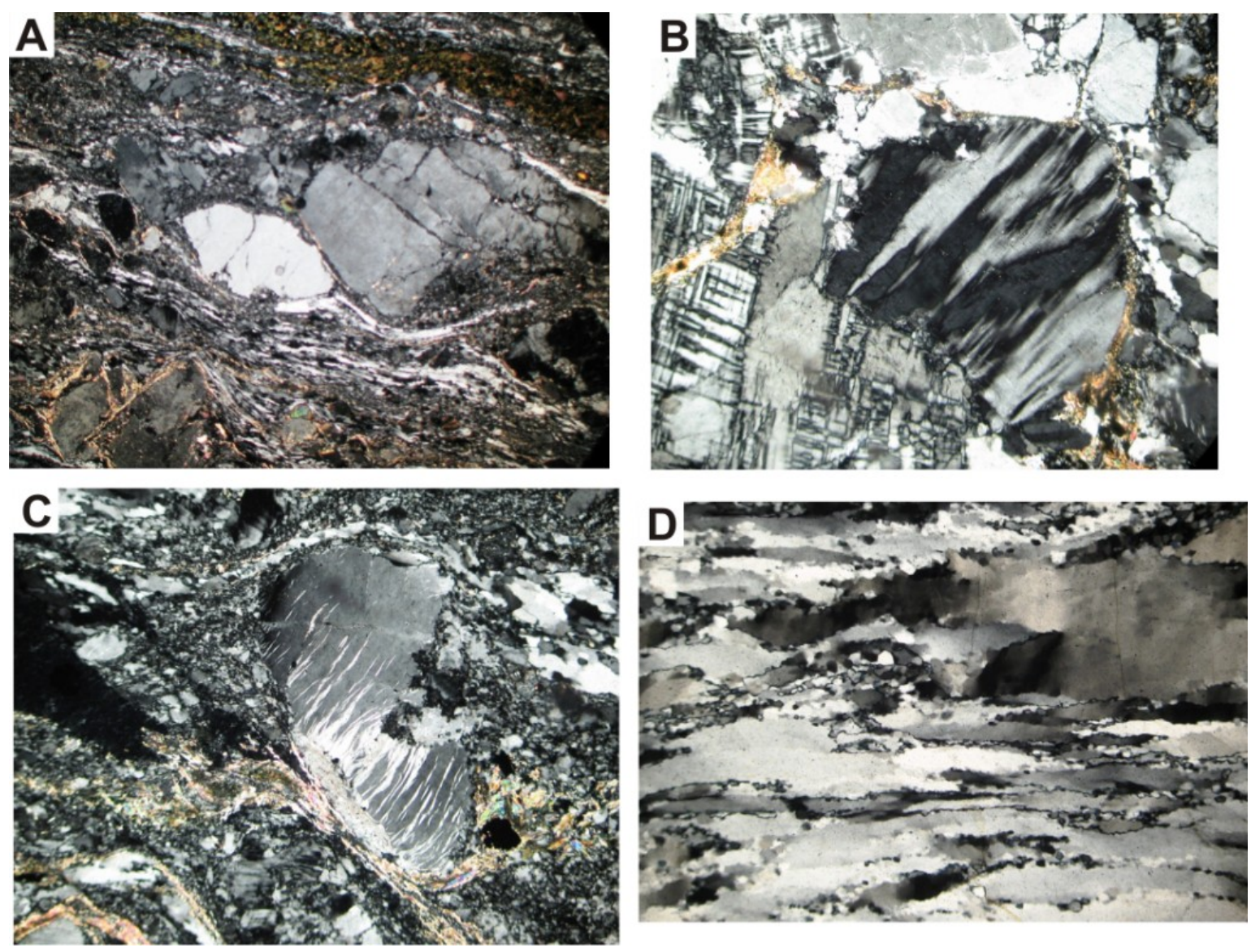

Prancha 3. Fotomicrografias de: (A) porfiroclasto de feldspato fraturado, com pequenos grãos rescritalizados no seu entorno; (B) feldspato exibindo lamelas de deformação; (C) porfiroclasto de feldspato com pertitas em chama; e (D) quartzo recristalizado dinamicamente por bulging.

Também há registros de forte recristalização estática (annealing) em várias lâminas, evidenciada por domínios onde o quartzo ocorre como grãos aproximadamente equidimensionais, com contato reto a $120^{\circ}$, poligonizados, formando textura de alto equilíbrio. Além disso, minerais micáceos representados pela biotita e muscovita se mostram dobrados e com extinção ondulante.

As poucas amostras de ultramilonitos foram coletadas em uma pedreira abandonada a sul de Tapiraí, no domínio estrutural E-W da Zona de Cisalhamento Caucaia. Este tipo de 
rocha de falha possui como minerais essenciais: quartzo, feldspato potássico, plagioclásio e biotita. Epídoto, clorita, turmalina, titanita, allanita, zircão e opacos ocorrem como minerais acessórios. A foliação milonítica é semelhante ao descrito anteriormente, com a diferença da menor granulação nos ultramilonitos.

Nos ultramilonitos verifica-se que o feldspato ocorre como porfiroclastos arredondados a sub-arredondados, localmente fraturados. Estes exibem feições de deformação intracristalina como extinção ondulante e pertitas em chama. No entorno dos porfiroclastos há grãos diminutos de feldspato recristalizado, o que sugere recristalização tipo bulging. Estes mesmos tipos de grãos são observados formando bandas na matriz da rocha de falha.

O quartzo ocorre como grãos anedrais, alongados, tamanho médio de $200 \mu \mathrm{m}$, contato lobulado e extinção ondulante. No entorno destes, há grãos alongados de quartzo recristalizado o que sugere predominância de recristalização dinâmica por rotação de subgrão.

\subsubsection{Indicadores cinemáticos microscópicos}

O sentido de cisalhamento da deformação associada à Zona de Cisalhamento Caucaia foi determinado através da observação dos seguintes indicadores cinemáticos microscópicos:

- Porfiroclasto manteado - corresponde a um fragmento rotacionado de feldspato potássico ou plagioclásio, no caso estudado, envolto por pequenos grãos recristalizados que formam uma espécie de manto ou cauda (Prancha 4.A). O formato deste último define o tipo de porfiroclasto manteado ( $\delta, \sigma$ ou complexo), e a assimetria do conjunto (manto + porfiroclasto) com relação à foliação milonítica indica o sentido de cisalhamento. Nas seções delgadas de milonitos e ultramilonitos, os porfiroclastos manteados tipo $\delta$ e $\sigma$ foram observados extensivamente, com predomínio de indicação de movimentação destral.

- Muscovita-fish - é caracterizada por muscovita deformada assimetricamente em forma de losango ou de lente, com forte orientação preferencial (Prancha 4.B). A assimetria entre o eixo maior da mica e o plano da foliação indica o sentido de cisalhamento, que no caso estudado foi destral.

- Foliação oblíqua - corresponde a agregados monominerálicos de quartzo com pequenos grãos recristalizados dinamicamente. Tais grãos são caracterizados por sua 
forma ligeiramente alongada e orientada. Esta orientação preferencial de forma dos grãos, em geral, é obliqua ao bandamento composicional do milonito, com ângulo entre 20 e $40^{\circ}$ (Prancha 4.C). A assimetria entre a direção de orientação preferencial e a foliação milonítica define o sentido de cisalhamento, que no caso estudado foi dominantemente destral.
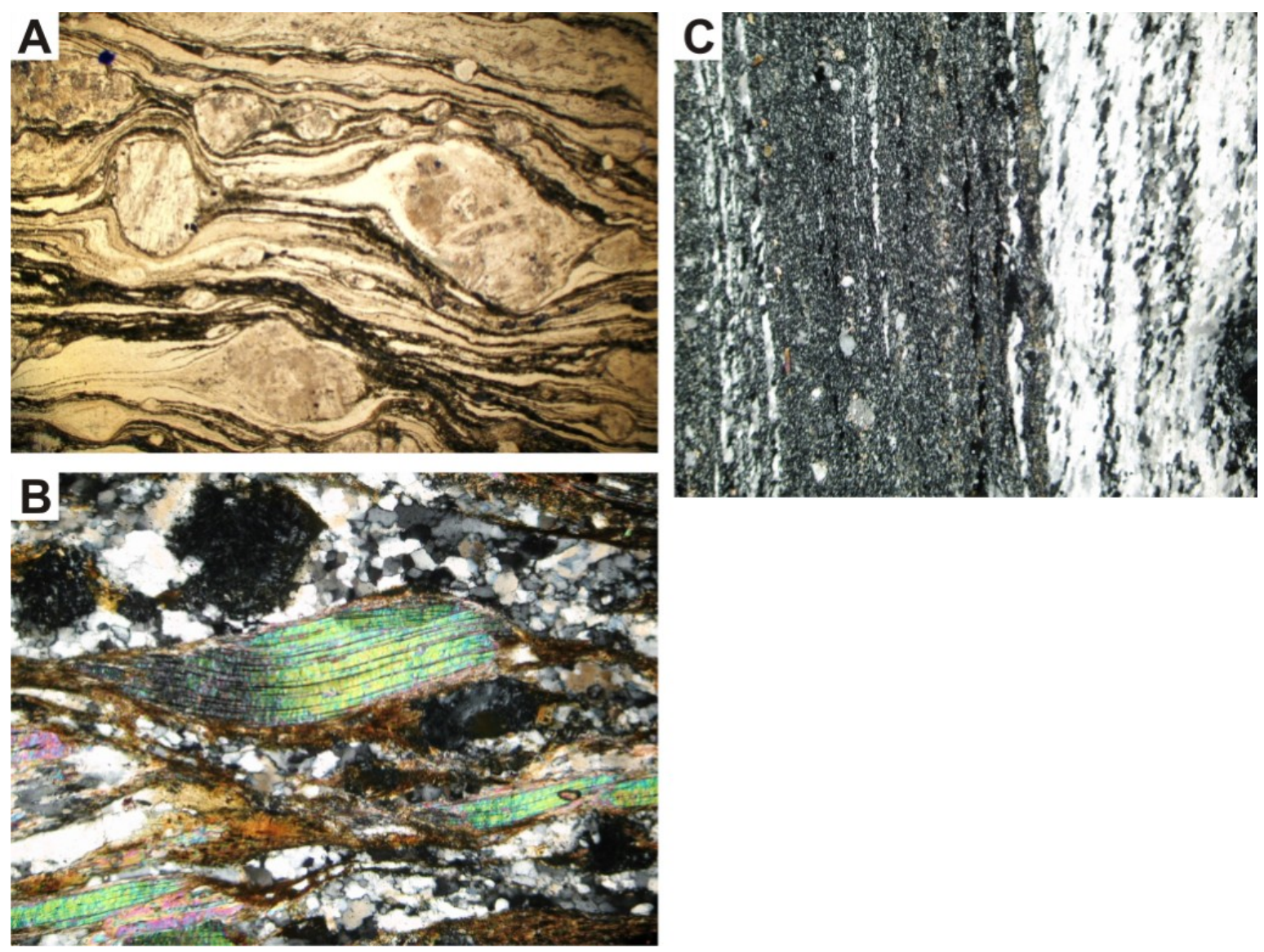

Prancha 4. Fotomicrografias de: (A) porfiroclasto manteado tipo $\sigma$, com indicação de movimentação sinistral; (B) muscovita-fish indicando movimentação destral; e (C) foliação oblíqua de quartzo, com indicação de movimentação sinistral.

\subsubsection{Condições de metamorfismo}

A análise microestrutural permite avaliar as condições de metamorfismo. Assim, a predominância de recristalização dinâmica por rotação de subgrão no quartzo, produzindo grãos alongados/achatados com extinção ondulante sugere condições de média temperatura. A biotita e a muscovita exibem dobras e kinks, bem como extinção ondulante. Este comportamento dúctil das micas indica temperatura superior a $250^{\circ} \mathrm{C}$ (Passchier e Trouw, 2005).

O comportamento dúctil-rúptil dos feldspatos é ressaltado pelos porfiroclastos fraturados em padrão dominó, e pela nucleação e crescimento de pequenos grãos 
recristalizados por processo de bulging. Tais grãos desenvolvem estruturas tipo núcleo e manto (core-and-matle structure), como porfiroclastos manteados assimétricos tipo delta e sigma. Tais feições, associadas aos indícios de forte deformação intracristalina como pertitas em chama, lamelas de geminação dobradas e lamelas de deformação, sugerem condições metamórficas de médio grau (transição entre os fácies xisto verde e anfibolito), com temperatura entre 450 e $600^{\circ} \mathrm{C}$, provavelmente ao redor de $500^{\circ} \mathrm{C}$ (Passchier e Trouw, 2005).

Também foram observadas feições típicas de deformação em nível mais raso, como fraturas e microfalhas. As fraturas ocorrem simplesmente cortando os milonitos ou, mais frequentemente, preenchidas por quartzo, epídoto e carbonato com aspecto fibroso. As microfalhas são oblíquas até perpendiculares à foliação milonítica. Constatou-se a ocorrência quase eqüitativa de microfalhas com movimentação destral e sinistral.
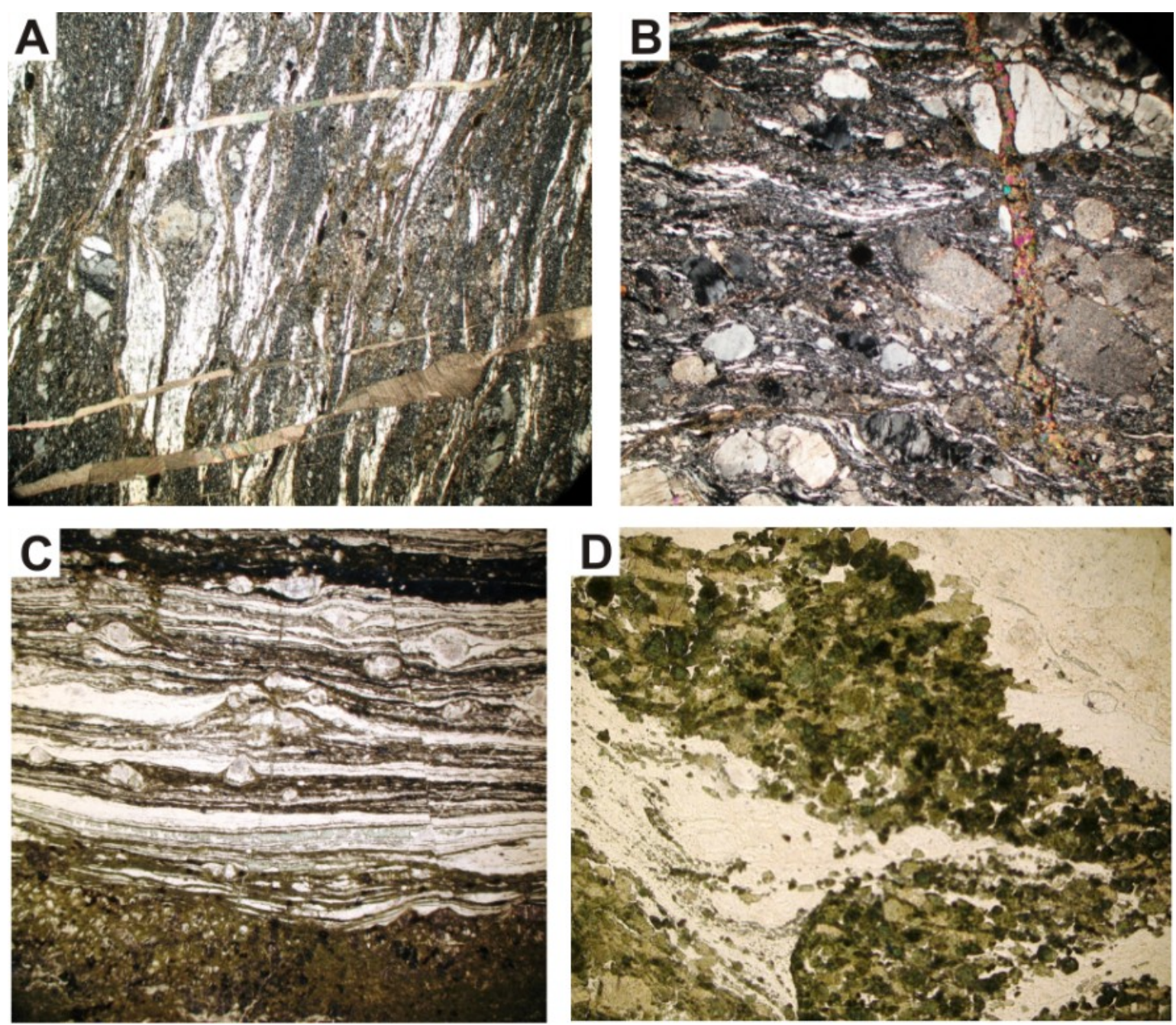

Prancha 5. Fotomicrografias de fraturas preenchidas por: (A) calcita fibrosa; e (B) epídoto. Fotomicrografias de (C) biotita hidrotermal na parte inferior da imagem; e (D) grãos de turmalina. 
A presença de fraturas preenchidas por quartzo, epídoto (Prancha 5.B) e carbonato fibroso (Prancha 5.A), bem como a ocorrência de concentrações anômalas de biotita (Prancha 5.C) e turmalina (Prancha 5.D) são indícios da ação de fluidos hidrotermais.

\subsection{Trama de eixos-c de quartzo}

\subsubsection{Descrição das tramas cristalográficas}

As tramas cristalográficas de eixos-c de quartzo de nove amostras (Figura 5.7), selecionadas ao longo da Zona de Cisalhamento Caucaia (Figura 5.8) foram enquadradas em quatro padrões fundamentais descritos abaixo:

(1) Os eixos-c tendem a se concentrar ao longo de guirlandas de círculos mínimos ao redor do eixo $\mathrm{Z}$ do elipsóide de deformação finita. Estas se conectam, à distância do eixo Y, através de uma guirlanda parcial inclinada entre $55^{\circ}$ e $79^{\circ}$, em relação ao plano de foliação milonítica e à lineação de estiramento. Assim, caracteriza-se a guirlanda cruzada tipo I de Lister (1977) assimétrica, representada pelas amostras CAU-09, 24, 29, 51 e 113. O ângulo de abertura dos círculos mínimos varia entre $32^{\circ}$ e $63^{\circ}$.

(2) Concentrações de eixos-c ao longo de um braço único, definido por um círculo máximo orientado a $82^{\circ}$, em relação ao plano de foliação e à lineação de estiramento. Entretanto, o círculo máximo apresenta-se dobrado na periferia do estereograma, caracterizando um padrão intermediário entre guirlanda cruzada tipo I e guirlanda simples assimétrica. O único representante deste padrão é a amostra CAU-112.

(3) Caracterizado por concentrações de eixos-c ao longo de um círculo máximo de alto mergulho, orientado em ângulos entre $65^{\circ}$ e $77^{\circ}$, em relação à foliação milonítica e à lineação de estiramento. Logo, tem-se a definição de uma guirlanda simples de círculo máximo, assimétrica, representada pelas amostras CAU-05 e 82. A primeira amostra apresenta sub-concentração formando uma guirlanda de círculo mínimo ao redor do eixo $\mathrm{X}$, similar a uma guirlanda tipo cleft. Entretanto, esta última provavelmente é resultante da intensa recristalização estática (annealing) do quartzo, o que acarreta no espalhamento da orientação dos eixos-c, gerando o padrão anômalo. 


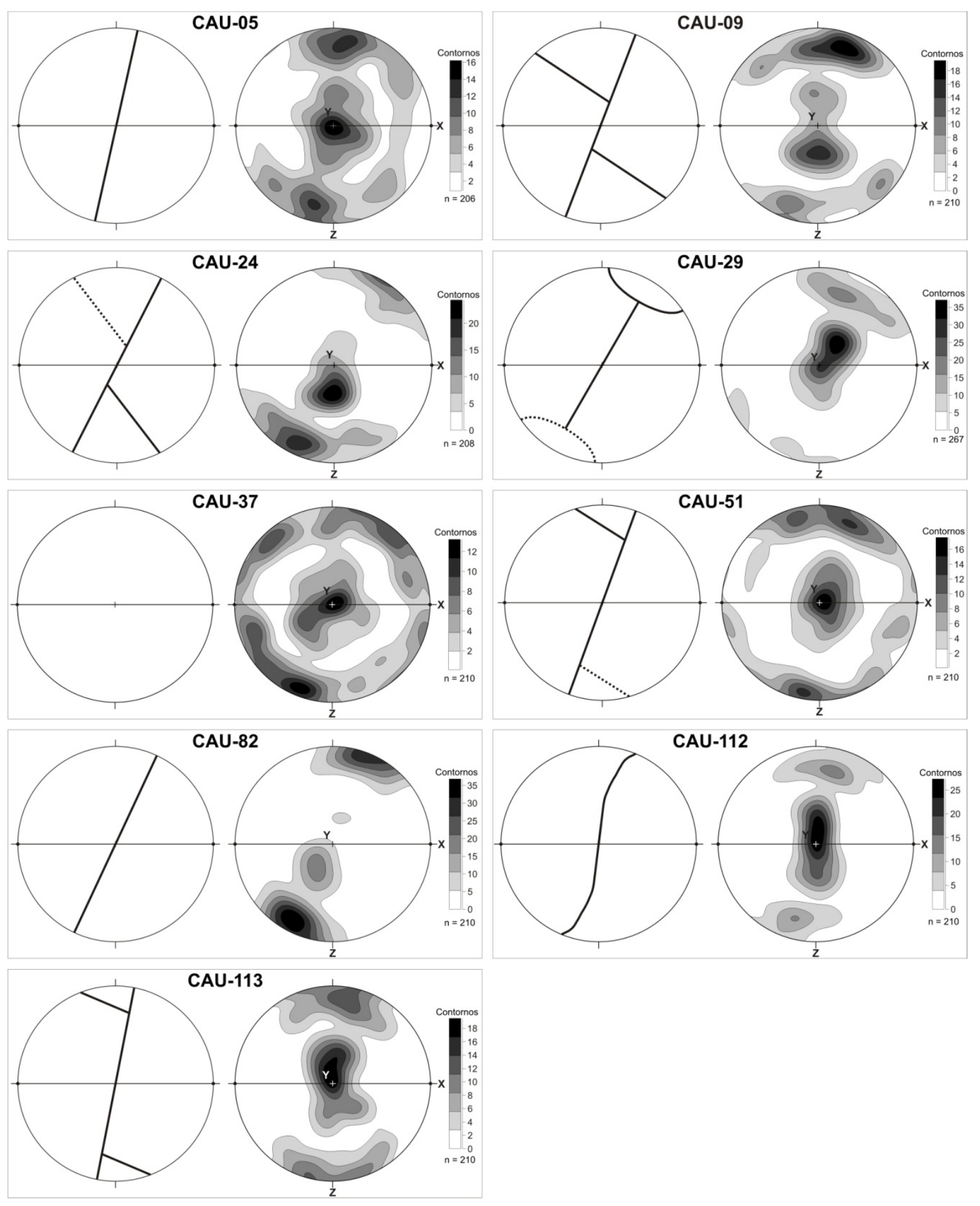

Figura 5.7. Trama de eixos-c de quartzo e esqueleto de trama (fabric skeleton) das nove amostras analisadas. 


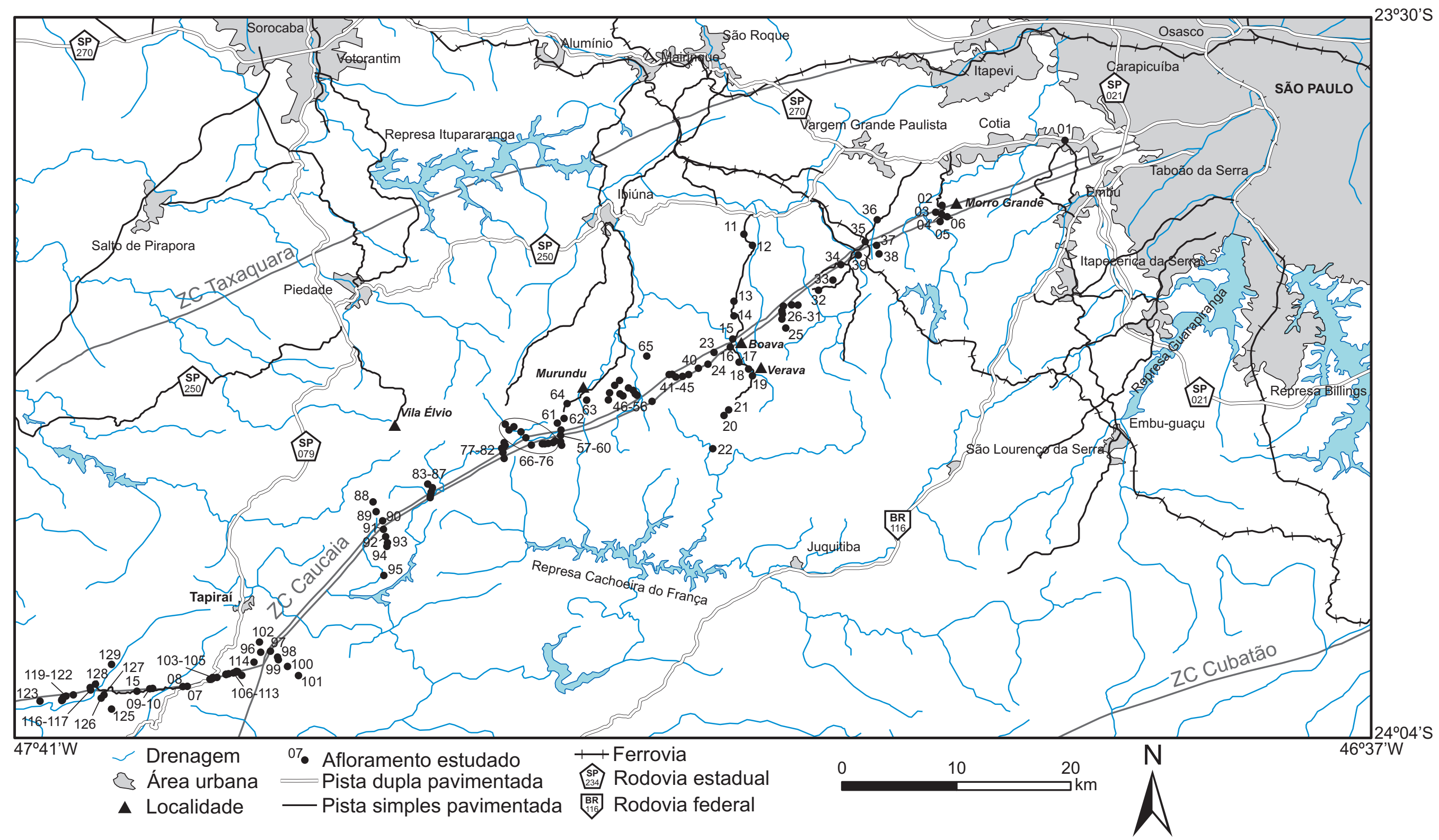

Figura 5.8. Mapa de pontos. 
(4) A amostra CAU-37 apresenta concentrações máximas de eixos-c ao redor dos eixos Y e $\mathrm{Z}$ do elipsóide de deformação finita. Além disso, várias sub-concentrações ocorrem ao longo da periferia do estereograma. Deste modo, a trama resultante não pode ser enquadrada em nenhum dos padrões clássicos descritos na literatura, caracterizando um padrão cristalográfico complexo. O forte espalhamento das medidas de eixos-c é decorrente da intensa e extensiva recristalização estática observada nos grãos de quartzo.

\subsubsection{Aspectos deformacionais}

A Zona de Cisalhamento Caucaia é caracterizada por tramas cristalográficas de eixos-c de quartzo em guirlanda cruzada tipo I assimétrica, guirlanda simples assimétrica, padrão de transição entre os dois primeiros tipos de trama, e padrão complexo, com concentrações máximas em $\mathrm{Y}$ e na região entre os eixos $\mathrm{X}$ e $\mathrm{Z}$ do elipsóide de deformação finita.

Tramas assimétricas em guirlanda simples e cruzada, bem como a transição entre estes padrões são indicativos de deformação não-coaxial (Schmid e Casey, 1986; Passchier e Trouw, 2005). Estes padrões são correlacionáveis com tramas previstas como resultante de cisalhamento simples, em modelagens numéricas baseadas na teoria de Taylor-BishopHill (Lister e Williams, 1979; Lister e Hobbs, 1980).

Pode-se inferir sentido de cisalhamento dominantemente destral para a Zona de Cisalhamento Caucaia, baseado na assimetria externa da trama cristalográfica, ou seja, considerando a obliqüidade da guirlanda com relação à foliação milonítica e à lineação de estiramento. Este sentido de rotação é reforçado pela assimetria interna da trama, caracterizada pela concentração preferencial de eixos-c ao longo do braço NE-SW da guirlanda cruzada.

Segundo Passchier (1983), tramas cristalográficas bem definidas, ou seja, com fabric skeleton nítido, e que possuam assimetrias interna e externa bem desenvolvidas, como observado nos casos estudados, podem seguramente ser utilizados como indicadores cinemáticos. Além disso, a cinemática destral da zona de cisalhamento é corroborada por dados microestruturais e estruturas observadas em escala de afloramento.

Tramas cristalográficas de eixos-c em guirlandas simples e cruzada tipo I são sugestivas de deformação plana (Sarkarinejad et al., 2010). Price (1985) considera que guirlandas cruzadas tipo I que apresentem guirlanda de círculo mínimo e guirlanda parcial 
sobre o eixo $\mathrm{Y}$ bem desenvolvidas estão associadas, respectivamente, à alta taxa de deformação e a maior componente de deformação plana relativamente ao achatamento.

Simulações numéricas realizadas por Lister e Hobbs (1980), considerando cisalhamento simples progressivo, mostram que, para altas deformações, os eixos-c de quartzo tendem a despovoar guirlandas e se reorientar segundo determinadas direções, resultando em concentrações máximas principais. Deste modo, a trama cristalográfica complexa representada pela amostra CAU-37 pode sugerir se tratar de uma porção mais deformada dentro da zona de cisalhamento. Entretanto, é mais provável que o padrão cristalográfico observado seja decorrente da obliteração da trama original provocada pela intensa recristalização estática (annealing).

Por fim, é interessante notar que os padrões das tramas cristalográficas obtidas neste estudo indicam, qualitativamente, deformação não-coaxial com aumento progressivo da componente rotacional da deformação (Schmid e Casey, 1986), como indicado no esquema da figura abaixo.

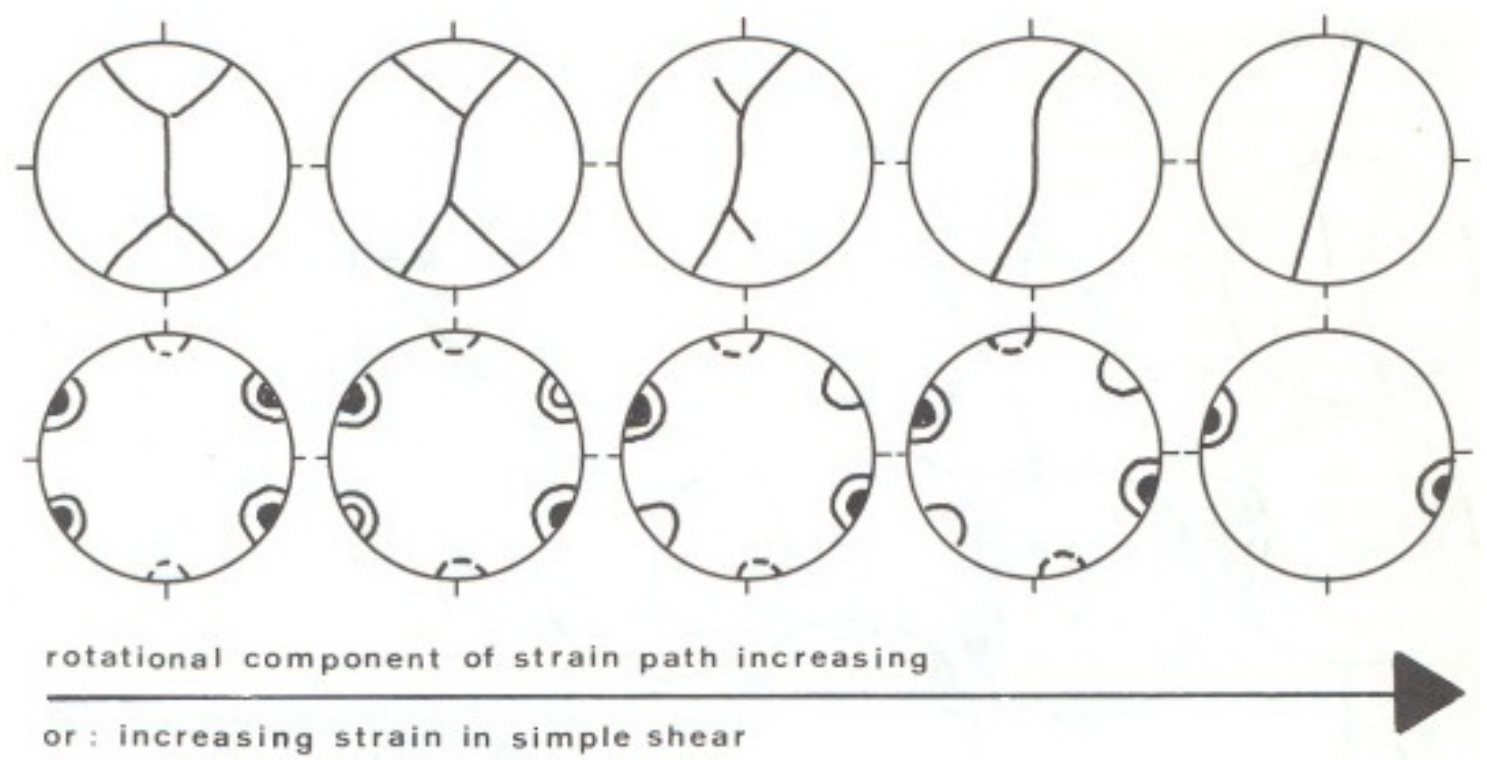

Figura 5.9. Tramas cristalográficas de eixos-c e eixos-a de quartzo esperadas para deformação não-coaxial, movimentação destral, considerando aumento progressivo da componente rotacional de deformação. Extraído de Schmid e Casey (1986).

\subsubsection{Sistemas de deslizamento cristalino ativados}

As rochas de falha do segmento E-W da Zona de Cisalhamento Caucaia são caracterizadas por tramas cristalográficas em guirlanda com concentrações máximas de eixos-c subparalelas à direção Y do elipsóide de deformação finita. Subordinadamente, ocorrem máximo e submáximos ao redor do eixo $\mathrm{Z}$ e na região intermediária entre $\mathrm{Y}$ e $\mathrm{Z}$. Tais concentrações indicam que na deformação do quartzo ocorreu ativação principal do 
sistema de deslizamento prismático $<\mathrm{a}>$, com contribuição do sistema basal $<\mathrm{a}>\mathrm{e}$, em menor grau, do romboédrico $<\mathrm{a}>$. Esta configuração sugere temperatura média a alta durante a deformação.

Por sua vez, o segmento principal da Zona de Cisalhamento Caucaia é marcado por tramas cristalográficas com concentrações máximas ao redor dos eixos $\mathrm{Y}$ e $\mathrm{Z}$ do elipsóide de deformação finita na maioria das amostras. Concentrações subordinadas de eixos-c ocorrem na região intermediária entre os eixos $\mathrm{Y}$ e Z. A distribuição dos máximos indica que a deformação no quartzo se deve à proeminente atividade dos sistemas de deslizamento prismático $<\mathrm{a}>$ e basal $<\mathrm{a}>$, com contribuição do sistema romboédrico $<\mathrm{a}>$. Esta configuração indica média temperatura de metamorfismo durante a deformação.

\subsubsection{Geotermômetro de Kruhl (1998)}

Foram selecionadas as cinco amostras caracterizadas por trama cristalográfica em guirlanda cruzada tipo I. Procedeu-se a medição do ângulo de abertura da guirlanda de círculo mínimo ao redor do eixo $Z$, onde foram obtidos valores entre $32^{\circ}$ e $63^{\circ}$ (Tabela 5.1). Além destas amostras, considerou-se o exemplar CAU-37, cuja trama é complexa, com máximos de concentração ao redor dos eixos $\mathrm{Y}$ e $\mathrm{Z}$ do elipsóide de deformação finita. Neste caso, foi medido um ângulo de $75^{\circ}$ entre duas concentrações máximas localizadas na periferia do estereograma.

Os valores do ângulo de abertura da guirlanda cruzada foram lançados no gráfico de Kruhl (1998), modificado por Law et al. (2004), que correlaciona ângulo de abertura de tramas de eixos-c de quartzo com temperatura de deformação.

Tabela 5.1. Valores medidos de ângulo de abertura entre guirlandas cruzadas e temperaturas estimadas pelo geotermômetro de Kruhl (1998).

\begin{tabular}{|c|c|c|c|}
\hline Domínio & Amostra & Angulo de abertura & Temperatura estimada \\
\hline \multirow{5}{*}{ NE-SW } & CAU-24 & $53^{\circ}$ & $(430 \pm 50)^{\circ} \mathrm{C}$ \\
& CAU-29 & $52^{\circ}$ & $(420 \pm 50)^{\circ} \mathrm{C}$ \\
& CAU-37 & $75^{\circ}$ & $(600 \pm 50)^{\circ} \mathrm{C}$ \\
& CAU-51 & $36^{\circ}$ & $(290 \pm 50)^{\circ} \mathrm{C}$ \\
\hline \multirow{2}{*}{ E-W } & CAU-09 & $63^{\circ}$ & $(500 \pm 50)^{\circ} \mathrm{C}$ \\
& CAU-113 & $32^{\circ}$ & $(260 \pm 50)^{\circ} \mathrm{C}$ \\
\hline
\end{tabular}


A partir dos dados obtidos no gráfico da figura 5.10, verifica-se que as amostras definem três intervalos de temperatura (Tabela 5.1):

- muito baixa - temperatura inferior a $300^{\circ} \mathrm{C}$ (amostras CAU-51 e 113);

- média - temperatura entre 400 e $500^{\circ} \mathrm{C}$ (amostras CAU-09, 24, 29);

- alta - temperatura de $600^{\circ} \mathrm{C}$ (amostra CAU-37).

Em condições metamórficas de muito baixo grau, o quartzo se deforma principalmente por fraturamento rúptil e dissolução por pressão (Passchier e Trouw, 2005). Entretanto, as amostras CAU-51 e 113 apresentam grãos e subgrãos de dimensões similares e forma alongada, indicando recristalização por rotação de subgrão. Este mecanismo de deformação é ativado em temperaturas superiores a $400^{\circ} \mathrm{C}$ (Stipp et al., 2002; Faleiros et al., 2010). Assim, há uma clara incompatibilidade entre a temperatura indicada pelas microestruturas daquela sugerida pelo geotermômetro de Kruhl (1998). Logo, temperatura a muito baixa obtida por este último método não pode ser considerada fidedigna.

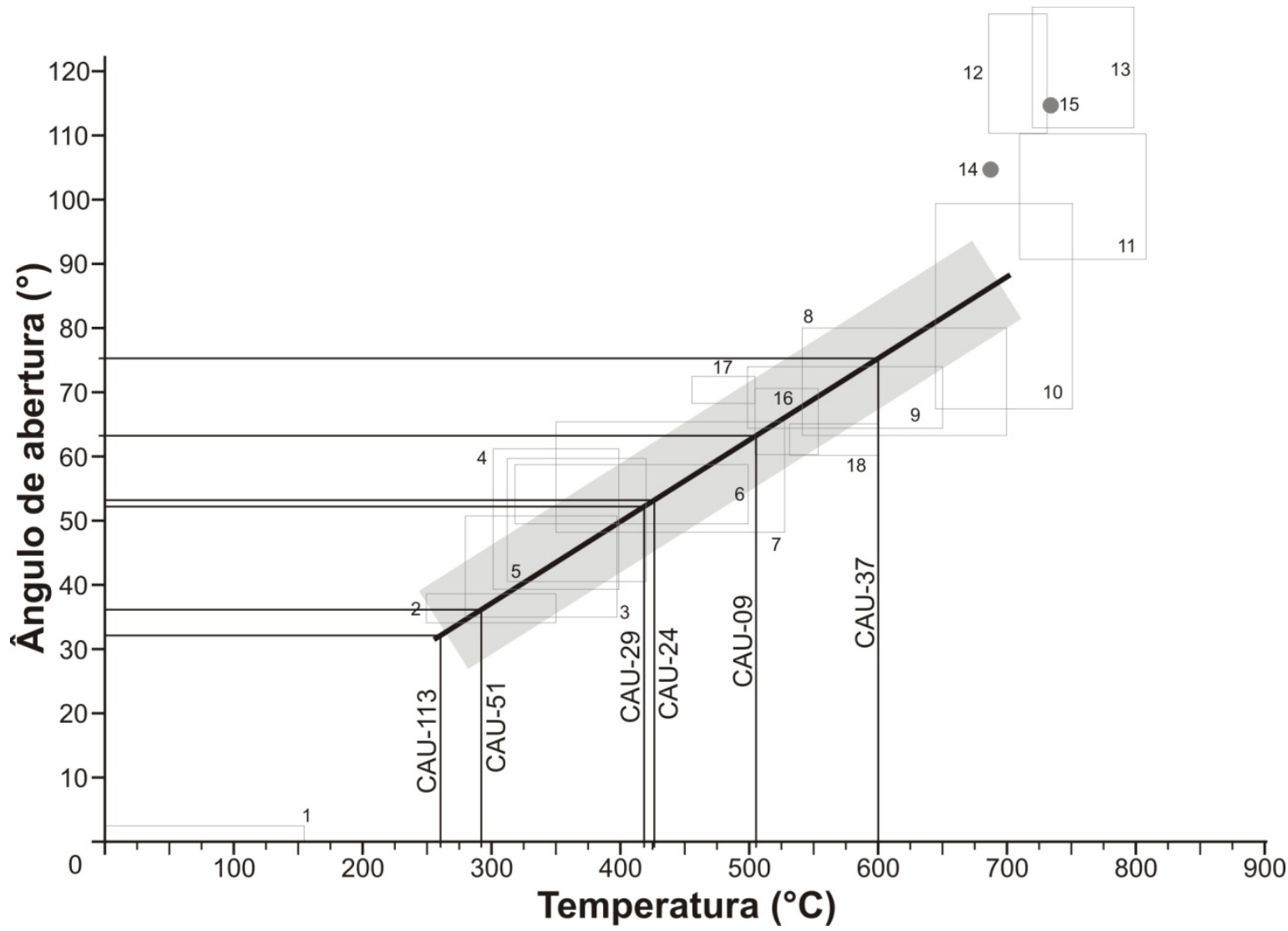

Figura 5.10. Temperaturas estimadas para seis amostras da Zona de Cisalhamento Caucaia, através da aplicação do geotermômetro de Kruhl (1998), modificado por Law et al. (2004). 
Não se sabe ao certo os efeitos da proporção relativa de outras fases minerais na orientação dos eixos-c de quartzo. Joy e Saha (1998) analisaram quartzitos contendo 2 a $35 \%$ de muscovita e clorita como impurezas, e concluíram que estas não influenciavam os padrões cristalográficos desenvolvidos. Por outro lado, no estudo da Zona de Cisalhamento Ribeira, Faleiros (2003) constatou que, quando a quantidade de micas (sericita) excede a de quartzo, o padrão cristalográfico observado é claramente divergente das demais amostras do mesmo litotipo ou pertencentes ao mesmo nível metamórfico/estrutural. Esta é uma possível explicação para o pequeno ângulo de abertura da guirlanda cruzada obtido para a amostra CAU-113, que corresponde a um biotita-quartzo-muscovita xisto feldspático.

As amostras CAU-09, 24 e 29 apresentam feldspatos com indícios de deformação intracristalina como geminação de deformação, geminação dobrada e pertitas em chama. $\mathrm{O}$ referido mineral pode ainda ocorrer como porfiroclastos fraturados e como finos grãos recristalizados. Tais feições microestruturais são indicativas de médio grau de metamorfismo, condizente com as temperaturas obtidas pela aplicação do geotermômetro de Kruhl (1998).

$\mathrm{Na}$ amostra CAU-37 a recristalização do feldspato é mais importante. Esta se dá por meio de bulging, promovendo a nucleação e crescimento de novos grãos ao redor dos porfiroclastos, formando estruturas do tipo núcleo e manto. Além disso, chama à atenção a ocorrência de texturas de intercrescimento tipo mirmequita. Logo, a indicação de temperatura de $(600 \pm 50)^{\circ} \mathrm{C}$ indicada pelo geotermômetro de Kruhl (1998) para esta amostra é perfeitamente possível.

\subsection{Análise de vorticidade}

Dois métodos de análise de vorticidade foram aplicados nas amostras da Zona de Cisalhamento Caucaia, a fim de caracterizar o fluxo ao longo desta estrutura. O primeiro é o método de rotação de porfiroclastos, cuja abordagem adotada corresponde à técnica da razão de forma de porfiroclastos proposta por Wallis et al. (1993). O segundo é o método da razão de forma/trama cristalográfica do quartzo proposta por Wallis (1995).

Os dois métodos envolvem observação e coleta de dados na seção paralela ao plano XZ de deformação finita, ou seja, perpendicular à foliação e paralela à lineação de 
estiramento. Pressupõe-se que o fluxo seja monoclínico, com vetor vorticidade paralelo ao eixo principal intermediário de deformação finita $(\mathrm{Y})$.

\subsubsection{Rotação de porfiroclastos rígidos}

Este método se baseia na orientação e razão de forma $(\mathrm{R})$ de porfiroclastos rígidos que rotacionam, sem interagir mecanicamente entre si, em meio a uma matriz que deforma ductilmente, e na determinação da razão de forma crítica $\left(\mathrm{R}_{\mathrm{C}}\right)$. Este valor crítico separa os porfiroclastos que rotacionam livremente $\left(\mathrm{R}<\mathrm{R}_{\mathrm{C}}\right)$ daqueles que tendem a posição de equilíbrio $\left(\mathrm{R}>\mathrm{R}_{\mathrm{C}}\right)$.

Foram selecionadas oito amostras de milonitos e protomilonitos da Zona de Cisalhamento, a partir das quais foram analisados, no mínimo, 152 porfiroclastos por amostra. Os porfiroclastos estudados são predominantemente de microclínio e oligoclásio, porém, em uma das amostras (CAU-37) também foram utilizados grãos de titanita.

Posteriormente, fez-se o gráfico do ângulo de orientação $(\varphi)$ do eixo maior do porfiroclastos em relação ao traço do plano de fluxo em função da razão de forma (R). Considerou-se o plano de fluxo como sendo paralelo ao plano de foliação milonítica, cujo traço no plano XZ de deformação finita coincide com a direção da cauda reta dos porfiroclastos manteados.

A partir dos gráficos, verificou-se que nas rochas naturalmente deformadas há uma transição gradativa entre os porfiroclastos que rotacionam livremente, e aqueles que tendem à posição de equilíbrio, como observaram Jessup et al. (2007). Isto torna o estabelecimento do limite entre estes dois campos algo arbitrário. Para contornar este problema foram definidos dois valores de razão de forma crítica $\left(\mathrm{R}_{\mathrm{C}}\right)$ para cada amostra, $\mathrm{o}$ que resulta em um intervalo de $\mathrm{W}_{\mathrm{m}}$, ao invés de um valor único.

Analisando os resultados obtidos neste método (Figura 5.11), verifica-se que o número médio de vorticidade $\left(\mathrm{W}_{\mathrm{m}}\right)$ foi estimado entre 0,62 e 0,82. Entretanto, a análise deste resultado requer atenção, uma vez que o número de vorticidade é definido por uma razão não-linear entre as componentes de deformação por cisalhamento simples e puro. Logo, tem-se que o resultado acima indica que a deformação associada à Zona de Cisalhamento Caucaia se processou por fluxo não-coaxial, com componente de cisalhamento simples entre $43 \%$ e $62 \%$. 

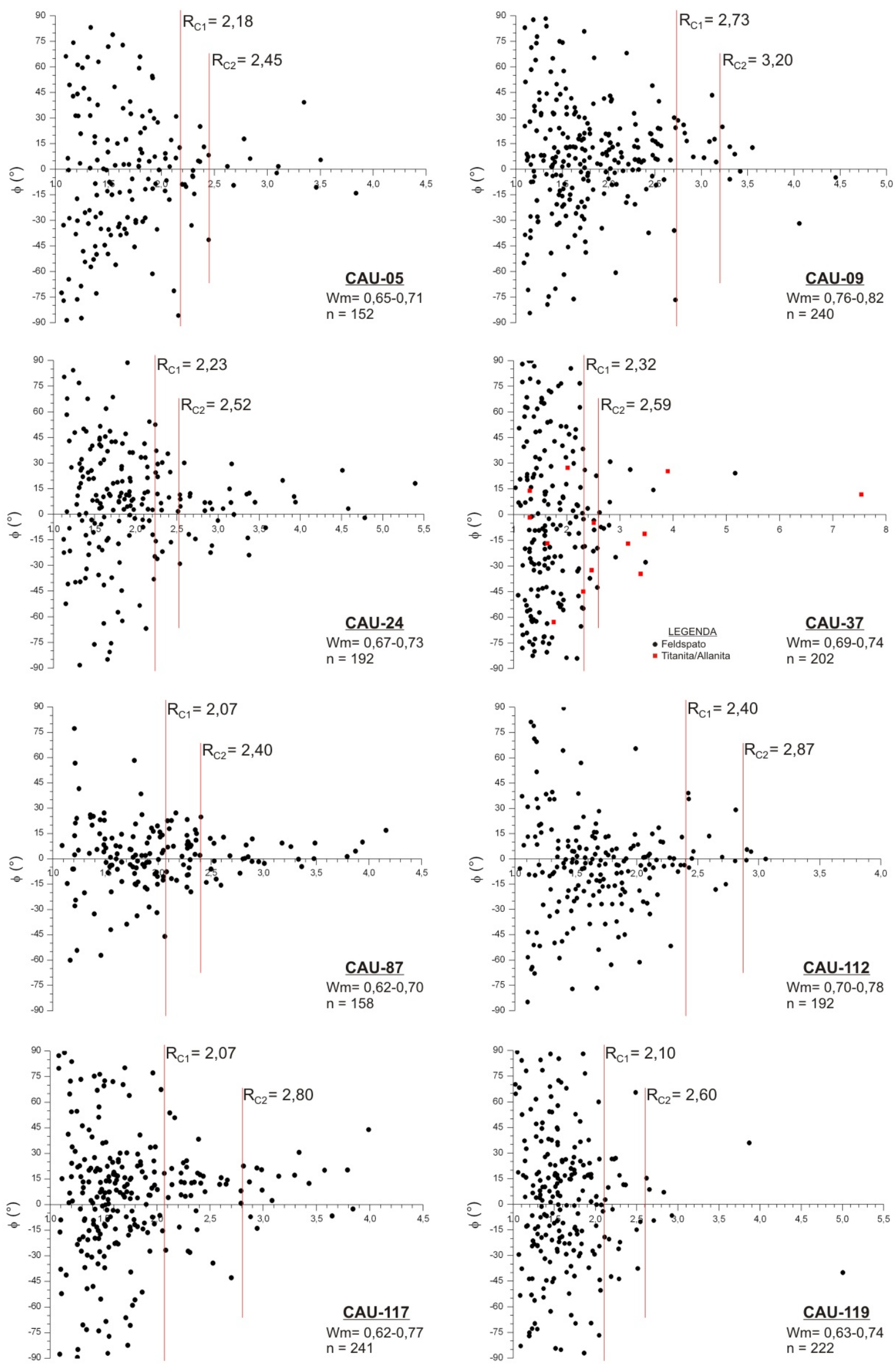

Figura 5.11. Gráficos do ângulo de orientação $(\varphi)$ em função da razão de forma $(R)$ dos porfiroclastos, onde são mostrados os valores de razão de forma crítica $\left(\mathrm{R}_{\mathrm{C}}\right)$ e intervalo do número médio de vorticidade $\left(\mathrm{W}_{\mathrm{m}}\right)$ para oito amostras analisadas da Zona de Cisalhamento Caucaia. 


\subsubsection{Razão de deformação finita/Trama de eixos-c de quartzo $\left(\mathrm{R}_{\mathrm{XZ}} / \beta\right)$}

Foram selecionadas sete amostras que apresentaram trama de eixos-c de quartzo com padrão em guirlanda simples e cruzada tipo I. Procedeu-se a medição do ângulo $\beta$ em cada uma delas, onde foram obtidos valores entre $7^{\circ}$ e $30^{\circ}$. Adotou-se um erro mínimo de $\pm 2^{\circ}$, como sugerido por Xypolias (2010), considerando o fato da guirlanda não ser perfeitamente delgada/definida.

O cálculo da razão de deformação finita principal $\left(\mathrm{R}_{\mathrm{XZ}}\right)$ de cada uma das amostras foi feita através da aplicação de, ao menos, um dos três métodos: tensor de inércia (Launeau e Cruden, 1998; Launeau e Robin, 2003), Rf/ $\varphi$ (Ramsay e Huber, 1983; Mulchrone e Meere, 2001) e Fry (Ramsay e Huber, 1983). A análise foi empreendida preferencialmente no quartzo da matriz das rochas miloníticas. Entretanto, três amostras apresentaram grãos de quartzo aproximadamente equidimensionais, com contatos retos a $120^{\circ}$, poligonizados, formando textura de alto equilíbrio, indicativa de recristalização estática (annealing). Estas feições inviabilizaram a utilização deste mineral na determinação da razão de deformação. Para tanto, foram utilizados os porfiroclastos de feldspato.

É sabido que o quartzo e o feldspato possuem comportamento reológico distinto. Além disso, há o problema da partição da deformação entre o material da matriz e os porfiroclastos. Apesar disso, nos três casos problemáticos, foram utilizados os resultados de razão de deformação finita obtidos na análise dos porfiroclastos de feldspato. Estes foram tomados como valores mínimos de referência, a fim de se aplicar o método $R_{X Z} / \beta$ de análise de vorticidade.

Utilizando os valores medidos de $\beta$ e da razão de deformação finita principal, calculou-se o número médio de vorticidade $\left(\mathrm{W}_{\mathrm{m}}\right)$ para as sete amostras analisadas (Tabela $5.2)$.

Analisando os dados da tabela acima, verifica-se que os números médios de vorticidade calculados variam ao longo da Zona de Cisalhamento Caucaia, não sendo possível determinar um valor médio de vorticidade para esta estrutura. Assim, pode-se analisar os resultados em termos de três faixas ou intervalos de vorticidade.

A primeira faixa, representada pelas amostras CAU-09, 24, 29 e 51, é caracterizada por altos números médios de vorticidade, entre 0,81 e 1,00, que indica fluxo não-coaxial com componente de cisalhamento simples mínimo de $61 \%$ até fluxo $100 \%$ por cisalhamento simples. 
Tabela 5.2. Razão de deformação finita principal $\left(\mathrm{R}_{\mathrm{XZ}}\right)$ para quartzo da matriz e/ou feldspato dos porfiroclastos, ângulo $\beta$ e número médio de vorticidade $\left(\mathrm{W}_{\mathrm{m}}\right)$ estimado para sete amostras da ZCC.

\begin{tabular}{|c|c|c|c|c|c|c|}
\hline \multirow{2}{*}{ Amostra } & \multicolumn{3}{|c|}{$\mathbf{R}_{\mathbf{x z}}$ (feldspato) } & $\mathbf{R}_{\mathbf{x z}}$ (quartzo) & \multirow{2}{*}{$\boldsymbol{\beta}$} & \multirow{2}{*}{$\mathbf{W}_{\mathbf{m}}$} \\
\cline { 2 - 5 } & $\mathbf{T . ~ I n e ́ r c i a ~}$ & $\mathbf{R f} / \boldsymbol{\varphi}$ & $\mathbf{F r y}$ & T. Inércia & & \\
\hline CAU-05 & 1,384 & 1,25 & 1,705 & $1,916^{*}$ & $(13 \pm 2)^{\circ}$ & $0,52-0,67$ \\
CAU-09 & 1,595 & 1,40 & $2,628^{*}$ & - & $(21 \pm 2)^{\circ}$ & $0,88-0,95$ \\
CAU-24 & $2,343^{*}$ & 1,45 & - & - & $(27 \pm 2)^{\circ}$ & $0,95-0,99$ \\
CAU-29 & - & - & - & $4,075^{*}$ & $(30 \pm 2)^{\circ}$ & $0,98-1,00$ \\
CAU-51 & - & - & - & $2,252^{*}$ & $(20 \pm 2)^{\circ}$ & $0,81-0,90$ \\
\hline CAU-112 & 1,425 & 1,45 & $2,259^{*}$ & - & $(7 \pm 2)^{\circ}$ & $0,28-0,48$ \\
\hline CAU-113 & - & - & - & $3,577^{*}$ & $(11 \pm 2)^{\circ}$ & $0,62-0,79$ \\
\hline
\end{tabular}

A faixa intermediária de valores de $\mathrm{W}_{\mathrm{m}}$, entre 0,52 e 0,79 , engloba as amostras CAU-05 e 113, e aponta para deformação por cisalhamento geral com $35 \%$ a $58 \%$ de componente de cisalhamento simples. Este resultado é similar àqueles obtidos na análise de vorticidade pelo método de rotação de porfiroclastos rígidos.

Há uma terceira faixa de baixa vorticidade, cujo único representante é a amostra CAU-112, e caracterizada por $\mathrm{W}_{\mathrm{m}}$ entre 0,28 e 0,48 . Assim, estima-se deformação por fluxo não-coaxial com $18 \%$ a $32 \%$ de componente de cisalhamento simples.

Os valores relativamente baixos de vorticidade obtidos nas amostras CAU-05, 112 e 113 se devem ao pequeno ângulo $\beta$ medido: entre $7^{\circ}$ e $13^{\circ}$, frente a ângulos superiores a $20^{\circ}$ nas demais amostras analisadas. A primeira amostra citada ainda detém a menor razão de deformação finita principal, inferior a 2 , que muito provavelmente está subestimada. 


\section{DISCUSSÃo}

Analisando os dados estruturais levantados em campo, constata-se que a Zona de Cisalhamento Caucaia (ZCC) é caracterizada por uma foliação milonítica empinada a vertical, de orientação média N49E infletindo para N74E pouco a sul de Tapiraí. Entretanto, observações de campo sugerem que o ramo NE-SW persiste mesmo após a passagem pela região da "inflexão", o que permite a sua divisão em dois segmentos: NESW e aproximadamente E-W.

O quartzo mostra-se, com frequência, fortemente estirado, caracterizando uma lineação de atitude 44/14 e 74/12, respectivamente nos segmentos NE-SW e E-W. Assim, tem-se a configuração de uma zona de cisalhamento direcional a oblíqua, com componente de rejeito direcional de caráter destral, e componente de rejeito de mergulho com bloco alto a sudeste.

Durante os trabalhos de campo não foram encontrados bons marcadores estruturais para se estimar a separação ou rejeito associado à Zona de Cisalhamento Caucaia. Além disso, a quantidade limitada de dados estruturais não permitiu questionar ou validar o modelo transpressivo atualmente aceito para a formação do Sistema de Zonas de Cisalhamento do Sudeste do Brasil, do qual a ZCC é componente.

A ZCC apresenta deformação de caráter dominantemente dúctil, afetando os granada-quartzo-muscovita-biotita xistos do Complexo Embu e dos hornblenda-biotita granitóides porfiríticos do Batólito Agudos Grandes. Estes últimos registram melhor a deformação, através da formação de belos exemplares de proto-, milonitos e até ultramilonitos portando porfiroclastos, geralmente, arredondados a sub-arredondados de microclínio pertítico róseo.

O sentido de movimentação da ZCC é dominantemente destral, assegurada pela observação de indicadores cinemáticos microscópicos (microestruturas como muscovitafish, porfiroclastos de feldspato fraturados e rotacionados, foliação $\mathrm{S}-\mathrm{C}$, foliação oblíqua e porfiroclastos manteados assimétricos tipo $\delta$ e $\sigma$ ); mesoscópicos (estrutura S-C, porfiroclastos manteados assimétricos tipo $\sigma$, boudin assimétrico e zonas de cisalhamento secundárias) e de trama cristalográfica de eixos-c de quartzo (assimetria de guirlandas simples e cruzada tipo I).

As condições metamórficas em que se processou a deformação associada à Zona de Cisalhamento Caucaia foram estimadas como condizentes com a transição entre os fácies 
xisto verde e anfibolito. Estas foram inferidas a partir de dados microestruturais e de trama cristalográfica, uma vez que, nenhuma paragênese mineral sin-milonítica conclusiva foi observada.

A análise da trama cristalográfica de eixos-c de quartzo permitiu inferir que na deformação deste mineral ocorreu ativação principal do sistema de deslizamento prismático $<\mathrm{a}>$, com contribuição do sistema basal $<\mathrm{a}>\mathrm{e}$, subordinadamente, do deslizamento romboédrico $<\mathrm{a}>$. Assim, tem-se a indicação qualitativa de média a alta temperatura de metamorfismo.

Ainda utilizando dados da trama cristalográfica, foi aplicado o geotermômetro semi-quantitativo de Kruhl (1998), a partir das medidas dos ângulos de abertura das guirlandas cruzadas. Deste modo, obteve-se uma estimativa de temperatura entre 400 e $600^{\circ} \mathrm{C}$, com erro de $\pm 50^{\circ} \mathrm{C}$.

A análise das microestruturas indica condições metamórficas de médio grau com temperatura entre 450 e $600^{\circ} \mathrm{C}$, provavelmente $500^{\circ} \mathrm{C}$. Tal estimativa se baseia no comportamento dúctil-rúptil do feldspato, com importante contribuição da recristalização, e nas feições de deformação intracristalina neste mesmo mineral. A predominância do processo de recristalização do quartzo por rotação de subgrão reforça esta estimativa (Passchier e Trouw, 2005).

Os padrões de trama cristalográfica obtidos para a ZCC são representados por guirlanda cruzada tipo I, transição entre este tipo e guirlanda simples, e guirlanda simples. Isto indica, qualitativamente, que a deformação não é exclusivamente devida ao cisalhamento simples, havendo uma importante componente de cisalhamento puro (Schmid e Casey, 1986). Esta constatação é reforçada pela ocorrência local de porfiroclastos manteados, assimétricos, tipo $\sigma$, rotacionados antiteticamente (back-rotated) à direção de cisalhamento.

Neste sentido, procedeu-se a análise de vorticidade em onze amostras, através da aplicação de dois métodos diferentes: rotação de porfiroclastos rígidos e razão de forma/trama de eixos-c de quartzo $\left(\mathrm{R}_{\mathrm{XZ}} / \beta\right)$. Os resultados obtidos são apresentados no diagrama da figura 6.1 .

Analisando os números médios de vorticidade, para o método de rotação de porfiroclastos rígidos, verifica-se que os resultados são similares, com $\mathrm{W}_{\mathrm{m}}$ estimado entre 0,62 e 0,82. Isto indica deformação por fluxo não-coaxial, com componente de cisalhamento simples entre $43 \%$ e $62 \%$. 
O segundo método de análise de vorticidade $\left(\mathrm{R}_{X Z} / \beta\right)$ resultou em três faixas de número de vorticidade. Há um intervalo de altos valores de $\mathrm{W}_{\mathrm{m}}$, entre 0,81 a 1,00 , que indica deformação por fluxo não-coaxial com componente de cisalhamento simples mínimo de $61 \%$ até fluxo exclusivamente por cisalhamento simples. A faixa intermediária apresenta valores de $\mathrm{W}_{\mathrm{m}}$ entre 0,52 e 0,79 , sugerindo deformação por cisalhamento geral com $35 \%$ a $58 \%$ de componente de cisalhamento simples. Por fim, há um intervalo de baixos valores de $\mathrm{W}_{\mathrm{m}}$, entre 0,28 e 0,48 , indicando fluxo não-coaxial com $18 \%$ a $32 \%$ de componente de cisalhamento simples.

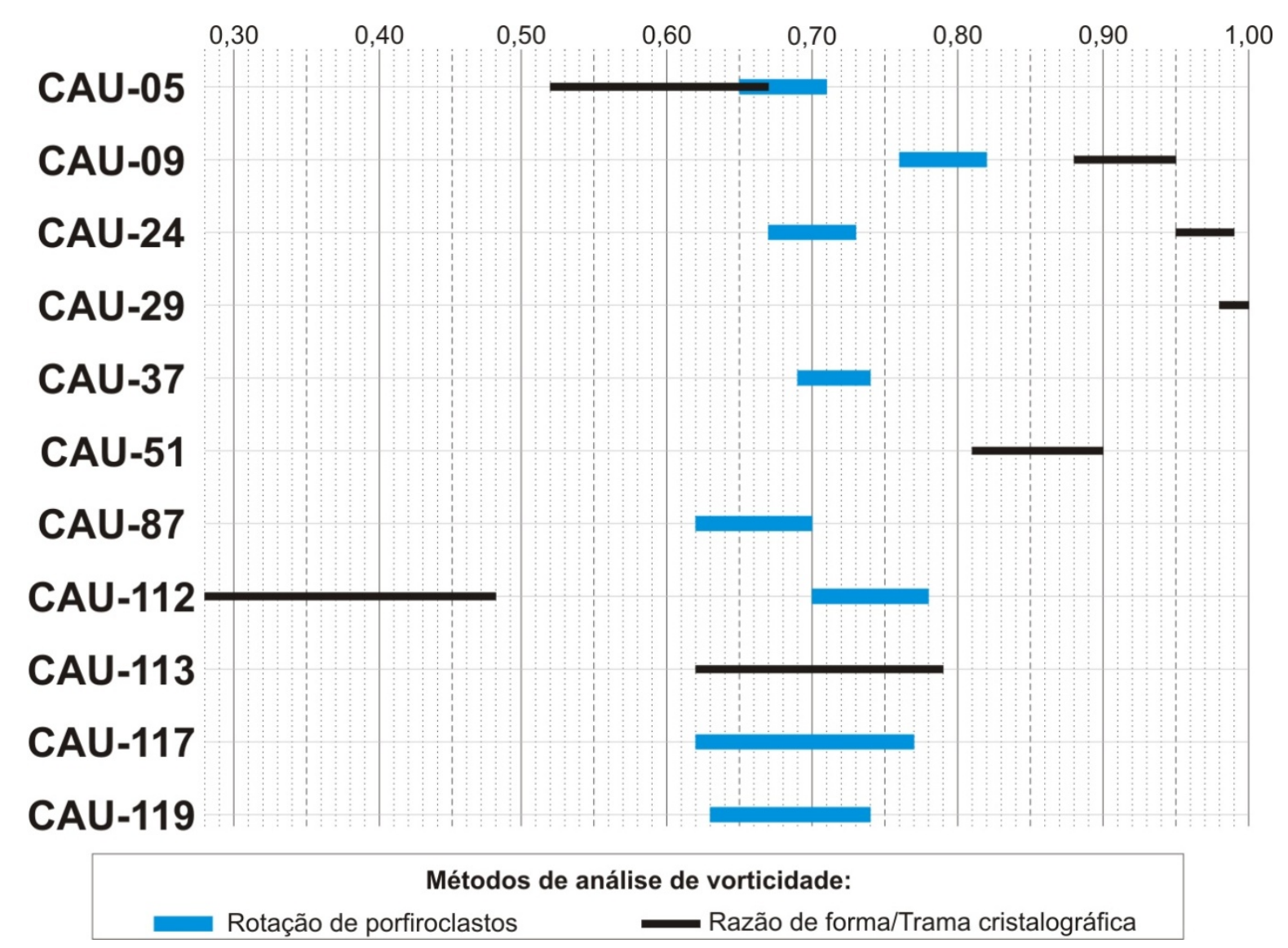

Figura 6.1. Diagrama comparativo mostrando o intervalo de valores de $\mathrm{W}_{\mathrm{m}}$ obtidos pelos métodos de rotação de porfiroclastos e $\mathrm{R}_{\mathrm{XZ}} / \beta$ para as onze amostras analisadas.

A faixa intermediária de número médio de vorticidade apresenta resultados similares àqueles obtidos na análise de vorticidade pelo método de rotação de porfiroclastos rígidos. Entretanto, a amostra CAU-05 apresenta a menor razão principal de deformação finita entre todas as amostras, valor este $\left(\mathrm{R}_{\mathrm{XZ}}=1,916\right)$ claramente subestimado, resultando em $\mathrm{W}_{\mathrm{m}}$ calculado menor que o real. Por sua vez, a amostra CAU-113 apresenta ângulos $\beta$ e de abertura entre as guirlandas muito pequenos. Assim, levantou-se a hipótese 
da composição desta rocha (biotita-quartzo-muscovita xisto feldspático), caracterizada pela maior quantidade de micas influir/modificar a trama cristalográfica do quartzo, como sugerido por Faleiros (2003)

A faixa inferior, representada pela amostra CAU-112, apresenta valores anormalmente baixos de $\mathrm{W}_{\mathrm{m}}$, indicando deformação por cisalhamento geral com até $82 \%$ de componente de cisalhamento puro. Esta seria uma evidência de transpressão, uma vez que a amostra foi coletada na região de inflexão (de E-W para NE-SW) da Zona de Cisalhamento Caucaia. Porém, outra amostra (CAU-113) coletada muito próxima desta resultou em número médio de vorticidade muito maior.

Os diversos métodos de análise de vorticidade apresentam diferentes graus de sensibilidade a mudanças no regime de fluxo. Logo, cada um destes registra uma parte discreta da história deformacional (strain memory) de uma zona de cisalhamento.

Segundo Xypolias (2010), os métodos de rotação de porfiroclastos rígidos e $R_{x z} / \beta$ registram boa parte da história deformacional de uma zona de cisalhamento, fornecendo valores consistentes de número médio de vorticidade ou, ao menos, apresentam uma significativa sobreposição no intervalo registrado da história deformacional. Deste modo, esperava-se que os intervalos de $\mathrm{W}_{\mathrm{m}}$ calculados por estes métodos fossem semelhantes. Entretanto, os resultados obtidos pelo método $\mathrm{R}_{\mathrm{XZ}} / \beta$ foram maiores que aqueles calculados através do método de rotação de porfiroclastos rígidos.

Considerando-se que a trama cristalográfica de eixos-c de quartzo é mais sensível a mudanças no fluxo, comparativamente à rotação dos porfiroclastos, ter-se-ia que o método $\mathrm{R}_{\mathrm{Xz}} / \beta$ registra a parte final da história deformacional. Neste caso, os resultados obtidos indicariam aumento na componente de cisalhamento simples nos incrementos finais da deformação dúctil associada à Zona de Cisalhamento Caucaia, implicando em trajetória acelerada de fluxo (accelerating flow path). Este resultado é sugestivo de transpressão na ZCC.

Diversos estudos mostram discrepância semelhante ao observado neste trabalho, e várias são as explicações sugeridas. Johnson (2009) aventa a possibilidade de que o método de rotação de porfiroclastos rígidos subestime o número médio de vorticidade. Isto aconteceria devido à lubrificação na interface porfiroclasto-matriz, contrariando o modelo de Jeffery (1922) que considera que os porfiroclastos são perfeitamente ligados à matriz.

Outra hipótese igualmente plausível seria de que o método $R_{X Z} / \beta$ superestima o número médio de vorticidade, caso o segmento central da guirlanda de eixos-c de quartzo rotacione sinteticamente à direção de cisalhamento na deformação progressiva, como 
sugerido por Law (2010). Isto acarretaria na medida de um valor maior do ângulo $\beta$ e, consequentemente, maiores valores de $\mathrm{W}_{\mathrm{m}}$.

Suspeita-se que a partição da deformação entre a matriz e os porfiroclastos possa influenciar na vorticidade registrada por cada um destes elementos constituintes das rochas miloníticas. Entretanto, no atual estágio de desenvolvimento dos métodos de análise de vorticidade é muito difícil distinguir entre todas estas possibilidades. Apesar disso, esta ferramenta possui grande potencial de uso em geologia estrutural, carecendo de mais estudos.

Por fim, foi observada uma inconsistência entre os métodos de análise de vorticidade utilizados. No método de rotação de porfiroclastos rígidos a orientação destes últimos tem como referência o traço do plano de fluxo, que geralmente é considerado como paralelo ao traço do plano de foliação milonítica. Por sua vez, no método $\mathrm{R}_{\mathrm{XZ}} / \beta$ uma das variáveis consideradas para calcular o número de vorticidade é justamente o ângulo $(\beta)$, oblíquo, entre os planos de fluxo e de foliação milonítica.

A eventual correção na orientação $(\varphi)$ dos porfiroclastos, decorrente do plano de fluxo ser oblíquo à foliação milonítica, resultaria apenas em uma translação (deslocamento ou offset) dos dados ao longo do eixo das ordenadas do gráfico de $\varphi$ em função da razão de forma. Isso não afetaria a distribuição dos dados, nem o número de vorticidade obtido. 


\section{CONCLUSÕES}

- A Zona de Cisalhamento Caucaia apresenta deformação de caráter dominantemente dúctil, sendo caracterizada por foliação milonítica aproximadamente vertical, com orientação média N49E, em um ramo, e N74E, em outro segmento, com forte lineação de estiramento de baixo ângulo com caimento para NE.

- A observação de indicadores cinemáticos (mesoscópicos, microscópicos e cristalográficos) predominantemente destrais, associada aos dados anteriores, sugere que a ZCC seja classificada como uma zona de cisalhamento direcional a oblíqua, com componente de rejeito direcional de caráter destral, e componente de rejeito de mergulho com bloco alto a sudeste.

- A deformação associada à Zona de Cisalhamento Caucaia se processou em condições metamórficas de transição entre os fácies xisto verde alto e anfibolito, com intervalo de temperatura entre 450 e $600^{\circ} \mathrm{C}$. Tal inferência baseou-se em dados microestruturais e de trama cristalográfica (sistemas de deslizamento cristalino ativados e geotermômetro de quartzo).

- Os padrões de trama de eixos-c de quartzo obtidos indicam que a deformação associada à ZCC não é exclusivamente devida ao cisalhamento simples, havendo uma importante componente de cisalhamento puro. Esta afirmação é corroborada pela observação de porfiroclastos manteados, assimétricos, tipo $\sigma$, rotacionados antiteticamente à direção de cisalhamento.

- A aplicação de dois métodos de análise de vorticidade resultou em valores de $\mathrm{W}_{\mathrm{m}}$ contrastantes: $0,62 \leq \mathrm{Wm} \leq 0,82$ (fluxo não-coaxial, com componente de cisalhamento simples entre $43 \%$ e $62 \%$ ) para o método de rotação de porfiroclastos rígidos; e $0,85 \leq \mathrm{Wm} \leq 1,00$ (fluxo não-coaxial, com componente de cisalhamento simples entre $65 \%$ até $100 \%$ ) para o método $\mathrm{R}_{\mathrm{XZ}} / \beta$.

- Considerando-se que o método $\mathrm{R}_{\mathrm{XZ}} / \beta$ registre a parte final da história deformacional da zona de cisalhamento, comparativamente ao método da rotação de porfiroclastos, ter-se-ia o aumento na componente de cisalhamento simples nos incrementos finais da deformação dúctil associada à Zona de Cisalhamento Caucaia. Isto implicaria em trajetória acelerada de fluxo (accelerating flow path) para a ZCC, concordante com o modelo de transpressão atualmente aceito para o Sistema de Zonas de Cisalhamento do Sudeste do Brasil. 


\section{REFERÊNCIAS BIBLIOGRÁFICAS}

ALMEIDA, F. F. M. Diferenciação tectônica da Plataforma Brasileira. In: CONGRESSO BRASILEIRO DE GEOLOGIA, 23., 1969. Salvador. Anais... Salvador: SBG, 1969. p. 2946.

ALMEIDA, J. C. H. Zonas de cisalhamento dúctil de alto grau do Médio Vale do Rio Paraíba do Sul. 2000. 190 f. Tese (Doutorado) - Instituto de Geociências e Ciências Exatas, Universidade Estadual Paulista, Rio Claro.

BASEI, M. A. S.; BRITO NEVES, B. B.; SIGA Jr, O.; BABINSKI, M.; PIMENTEL, M. M.; TASSINARI, C. C. G.; HOLLANDA, M. H. B.; NUTMAN, A.; CORDANI, U. G. Contribution of SHRIMP U-Pb zircon geochronology to unravelling the evolution of Brazilian Neoproterozoic fold belts. Precambrian Research, Amsterdam, v. 183, p. $112-$ $144,2010$.

BORGES, F. S. Análise cinemática de zonas de cisalhamento. Revista Electrónica de Ciências da Terra, v. 23, n. 1, p. 1-28, 2010.

BRASIL. Ministério das Minas e Energia. CPRM. Folha SF.23-Y-C São Paulo. Brasília: CPRM, 1999. 1 mapa, color., 58cmx120cm . Programa Levantamentos Geológicos Básicos do Brasil. Escala 1:250.000.

BRASIL. Ministério das Minas e Energia. CPRM. Carta Geológica do Brasil ao milionésimo: folhas SF.23 Rio de Janeiro e SG.23 Iguape. Brasília: CPRM, 2004. 1 CDROM

CAMPANHA, G. A. C. O Lineamento de Além-Paraíba na área de Três Rios (RJ).1980. 109 f. Dissertação (Mestrado) - Instituto de Geociências, Universidade de São Paulo, São Paulo.

CAMPANHA, G. A. C. O Lineamento de Além-Paraíba na área de Três Rios, RJ. Revista Brasileira de Geociências, São Paulo, v. 11, n. 3, p. 159-171, 1981.

CAMPANHA, G. A. C. Tectônica proterozóica no alto e médio Vale do Ribeira, estados de São Paulo e Paraná. 1991. 2 v. Tese (Doutorado) - Instituto de Geociências, Universidade de São Paulo, São Paulo.

CAMPANHA, G. A. C. O papel do Sistema de Zonas de Cisalhamento Transcorrentes na configuração da porção meridional da Faixa Ribeira. 2002. 138 f. Tese (Livre-Docência) - Instituto de Geociências, Universidade de São Paulo, São Paulo.

CAMPANHA, G. A. C. O papel do sistema de zonas de cisalhamento transcorrentes na evolução do Cinturão Ribeira. In: SIMPÓSIO NACIONAL DE ESTUDOS TECTÔNICOS, 12., 2009. Ouro Preto. Programa e Resumos... Ouro Preto: SBG - Núcleo MG, 2009. p. 97. 
CAMPANHA, G. A. C.; SADOWSKI, G. R. Tectonics of the southern portion of the Ribeira Belt (Apiaí Domain). Precambrian Research, Amsterdam, v. 98, n. 1, p. 31-51, 1999.

CAMPOS NETO, M. C. Orogenic systems from southwestern Gondwana. An approach to Brasiliano-Pan African Cycle and orogenic collage in southeastern Brazil. In: CORDANI, U. G.; MILANI, E. J.; THOMAZ FILHO, A.; CAMPOS, D. A. (Eds.). INTERNATIONAL GEOLOGICAL CONGRESS, 31th, 2000, Rio de Janeiro. Tectonic Evolution of South America... Rio de Janeiro: SBG, 2000. p. 335-365.

CORDANI, U. G.; COUTINHO, J. M. V.; NUTMAN, A. P. Geochronological constraints on the evolution of the Embu Complex, São Paulo, Brasil. Journal of South American Earth Sciences, Amsterdam, v. 14, n. 8, p. 903-910, 2002.

COUTINHO, J. M. V. Petrologia do pré-cambriano em São Paulo e arredores. Boletim IGUSP, São Paulo, v. 3, p. 5-99, 1972.

FALEIROS, F. M. Zona de Cisalhamento Ribeira: deformação, metamorfismo e termobarometria de veios sin-tectônicos. 2003. 143 f. Dissertação (Mestrado) - Instituto de Geociências, Universidade de São Paulo, São Paulo.

FALEIROS, F. M.; CAMPANHA, G. A. C.; BELLO, R. M. S.; FUZIKAWA, K. Quartz recrystallization regimes, c-axis texture transitions and fluid inclusion reequilibration in a prograde greenschist to amphibolite facies mylonite zone (Ribeira Shear Zone, SE Brazil). Tectonophysics, Amsterdam, v. 485, p. 193-214, 2010.

FALEIROS, F. M.; CAMPANHA, G. A. C.; MARTINS, L.; VLACH, S. R. F.; VASCONCELOS, P. M. Ediacaran high-pressure collision metamorphism and tectonics of the southern Ribeira Belt (SE Brazil): Evidence for terrane accretion and dispersion during Gondwana assembly. Precambrian Research, Amsterdam, v. 189, p. 263-291, 2011.

FERNANDES, A. J.; CAMPOS NETO, M. C.; FIGUEIREDO, M. C. H. O Complexo Embu no leste do estado de São Paulo: limites e evolução geológica. In: CONGRESSO BRASILEIRO DE GEOLOGIA, 36., 1990, Natal. Anais... Natal: SBG/Núcleo Nordeste, 1990, v. 6, p. 2755-2763.

FIORI, A. P. Avaliação preliminar do deslocamento dúctil das falhas de Lancinha e de Morro Agudo no estado do Paraná. Boletim Paranaense de Geociências, Curitiba, n.36, p. 15-30, 1985.

GHOSH, S. K.; RAMBERG, H. Reorientation of inclusions by combination of pure shear and simple shear. Tectonophysics, Amsterdam, v. 34, p. 1-70, 1976.

HACKSPACHER, P. C.; TEIXEIRA, W.; DANTAS, E. L.; FETTER, A.; EBERT, H. D.; TROUW, R. A. J.; VASCONCELOS, P. Cooling and exumation of the final Brasiliano Orogeny at the southern Brasilia Belt and superposition with the Ribeira Belt: U/Pb and Ar/Ar methodologies. Journal of the Virtual Explorer (Online), v. 17, 2004.

HASUI, Y. Tectônica da área das folhas de São Roque e Pilar do Sul. 1973. 196 f. Tese (Livre-Docência) - Instituto de Geociências, Universidade de São Paulo, São Paulo. 
HASUI, Y. Geologia da folha de São Roque. Boletim IG-USP, São Paulo, v. 6, p. 157-183, 1975a.

HASUI, Y. Evolução polifásica do precambriano a oeste de São Paulo. Boletim IG-USP, São Paulo, v. 6, p. 95-108, 1975 b.

HASUI, Y.; CARNEIRO, C. D. R.; COIMBRA, A. M. The Ribeira Folded Belt. Revista Brasileira de Geociências, São Paulo, v. 5, n. 4, p. 257-262, 1975.

HASUI, Y.; SADOWSKI, G. R. Evolução geológica do pré-cambriano na região sudeste do estado de São Paulo. Revista Brasileira de Geociências, São Paulo, v. 6, n. 3, p. 182200, 1976.

HEILBRON, M.; PEDROSA SOARES, A. C.; CAMPOS NETO, M.C.; SILVA, L. C.; TROUW, R. A. J.; JANASI, V. A. Província Mantiqueira. In: MANTESSO NETO, V.; BARTORELli, A.; CARNEIRO, C. D. R.; BRITO NEVES, B. B. (Eds.) Geologia do Continente Sul-Americano: Evolução da Obra de Fernando Flávio Marques de Almeida. São Paulo: Beca, 2004. p. 203-234.

HOBBS, B. E.; MEANS, W. D.; WILLIANS, P .F. An outline of structural geology. New York: John Willey \& Sons, 1976. 571 p.

IACOPINI, D.; CAROSI, R.; XYPOLIAS, P. Implications of complex eigenvalues in homogeneous flow: a three-dimensional kinematic analysis. Journal of Structural Geology, Amsterdam, v. 32, p. 93-106, 2010.

JANASI, V. A.; VASCONCELlOS, A. C. B. C.; VLACH, S. R. F.; MOTIDOME, M. J. Granitóides da região entre as cidades de São Paulo e Piedade (SP): faciologia e contexto tectônico. In: CONGRESSO BRASILEIRO DE GEOLOGIA, 36., 1990, Natal. Anais... Natal: SBG /Núcleo Nordeste, 1990. v. 4, p. 1925-1935.

JANASI, V. A; ULBRICH, H. H. G. J. Late Proterozoic granitoid magmatism in the state of São Paulo, southeastern Brazil. Precambrian Research, Amsterdam, v.51, p. 351-374, 1991.

JANASI, V. A.; LEITE, R. J.; Van SCHMUS, W. R. U/Pb chronostratigraphy of the granitic magmatism in the Agudos Grandes Batholith (west of São Paulo, Brazil) implications for the evolution of the Ribeira Belt. Journal of South American Earth Sciences, Amsterdam, v. 14, n. 4, p. 363-376, 2001.

JANASI, V. A.; LIMA, R. B. Gnaisses da Grande São Paulo: geologia, petrografia e geoquímica dos granito gnássicos do extremo leste do Batólito Agudos Grandes. In: SIMPÓSIO DE GEOLOGIA DO SUDESTE, 8., 2003, São Pedro. Boletim de Resumos... São Paulo: SBG - Núcleo SP, 2003. p. 36.

JEFFERY, G. B. The motion of ellipsoidal particles immersed in a viscous fluid. Proceedings of the Royal Society, London, v. 102, p. 161-179, 1922. 
JESSUP, M. J.; LAW, R. D.; FRASSI, C. The rigid grain net (RGN): an alternative method for estimating mean kinematic vorticity number $\left(\mathrm{W}_{\mathrm{m}}\right)$. Journal of Structural Geology, Amsterdam, v. 29, p. 411-421, 2007.

JOY, S.; SAHA, D. Influence of micaceous impurity on dynamically recrystallized quartz c-axis fabric in L-S tectonites from the Singhbhum Shear Zone and its footwall, Eastern India. Journal of Structural Geology, Amsterdam, v. 20, n. 11, p. 1509-1520, 1998.

KRUHL, J. H. Reply: Prism- and basal-plane parallel subgrain boundaries in quartz: a microstructural geothermobarometer. Journal of Metamorphic Petrology, v. 16, p. 142146, 1998.

LAUNEAU, P.; CRUDEN, A. R. Magmatic fabric acquisition mechanisms in a syenite: results of a combined anisotropy of magnetic suscetibility and image analysis study. Journal of Geophysical Research, v. 103, p. 5067-5089. 1998.

LAUNEAU, P.; ROBIN, P.Y.F. 2003. SPO2003 v.6 (freeware). Université de Nantes (França)/University of Toronto (Canadá). Disponível em: http://www.sciences.univnantes. fr/geol/UMR6112/SPO/SPO.html. Acessado em 09/01/2012.

LAW, R. D. Moine Thrust zone mylonites at the Stack of Glencoul: II - results of vorticity analyses and their tectonic significance. In: LAW, R. D.; BUTLER, R. W. H.; HOLDSWORTH, R. E.; KRABBENDAM, M.; STRACHAN, R. A. (Eds) Continental Tectonics and Mountain Building: The Legacy of Peach and Horne. London: Geological Society of London, 2010. Special Publications, v. 335, p. 579-602.

LAW, R. D.; SEARLE, M. P.; SIMPSON, R. L. Strain, deformation temperatures and vorticity of flow at the top of the Greater Himalayan Slab, Everest Massif, Tibet. Journal of the Geological Society, London, v. 161, p. 305-320, 2004.

LEITE, R. J.; HEAMAN, L. M.; JANASI, J. A.; MARTINS, L.; CREASER, R. A. The late- to postorogenic transition in the Neoproterozoic Agudos Grandes Granite Batholith (Apiaí Domain, SE Brazil): constraints from geology, mineralogy, and $\mathrm{U} / \mathrm{Pb}$ geochronology. Journal of South American Earth Sciences, Amsterdam, v. 23, n. 2-3, p. 193-212, 2007.

LISTER, G. S. Crossed-girdle c-axis fabrics in quartzites plastically deformed by plane strain and progressive simple shear. Tectonophysics, Amsterdam, v. 39, p. 51-54, 1977.

LISTER, G. S.; WILLIAMS, P. F. Fabric development in shear zones: theoretical controls and observed phenomena. Journal of Structural Geology, Amsterdam, v. 1, n. 4, p. 283297, 1979.

LISTER, G. S.; HOBBS, B. E. The simulation of fabric development during plastic deformation and its application to quartzite: the influence of deformation history. Journal of Structural Geology, Amsterdam, v. 2, p. 355-370, 1980.

LISTER, G. S.; DORNSIEPEN, U. F. Fabric transitions in the Saxony Granulite Terrain. Journal of Structural Geology, Amsterdam, v. 4, n. 1, p. 81-92, 1982. 
LISTER, G. S.; WILLIAMS, P. F. The partitioning of deformation in flowing rock masses. Tectonophysics, Amsterdam, v. 92, p. 1-33, 1983.

MACHADO, R.; ENDO, I. Cinturão de Cisalhamento Atlântico: um exemplo de tectônica transpressional neoproterozóica. In: SIMPÓSIO NACIONAL DE ESTUDOS TECTÔNICOS, 4., 1993, Belo Horizonte. Boletim... Belo Horizonte: SBG/Núcleo MG, 1993. p. 189-191.

MEANS, W. D. Rotational quantities in homogeneous flow and the development of smallscale structure. Journal of Structural Geology, Amsterdam, v. 16, p. 437-445, 1994.

MEANS, W. D.; HOBBS, B. E.; LISTER, G. S.; WILLIAMS, P. F. Vorticity and noncoaxiality in progressive deformations. Journal of Structural Geology, Amsterdam, v. 2, p. 371-378, 1980.

MULCHRONE, K. F.; MEERE, P. A. A Windows program for the analysis of tectonic strain using deformed elliptical markers. Computers and Geosciences, v. 27, p. 1251-1255, 2001.

PASSARELLI, C. R.; BASEI, M. A. S.; WEMMER, K.; SIGA Jr, O.; OYHANTÇABAL, P. Major shear zones of southern Brazil and Uruguay: escape tectonics in the eastern border of Rio de La plata and Paranapanema cratons during the Western Gondwana amalgamation. International Journal of Earth Sciences (Geologische Rundschau), v. 100, n. 2-3, p. 391-414, 2011.

PASSCHIER, C. W. The reliability of asymmetric c-axis fabrics of quartz to determine sense of vorticity. Tectonophysics, Amsterdam, v. 99, p. T9-T18, 1983.

PASSCHIER, C. W. Flow in natural shear zones e the consequences of spinning flow regimes. Earth and Planetary Science Letters, v. 77, p. 70-80, 1986.

PASSCHIER, C. W. Stable positions of rigid objects in non-coaxial flow e a study in vorticity analysis. Journal of Structural Geology, Amsterdam, v. 9, p. 679-690, 1987.

PASSCHIER, C. W. The fabric attractor. Journal of Structural Geology, Amsterdam, v. 19, p. 113-127, 1997.

PASSCHIER, C. W. Monoclinic model shear zones. Journal of Structural Geology, Amsterdam, v. 20, p. 1121-1137, 1998.

PASSCHIER, C. W.; TROUW, R. A. J. Microtectonics. 2nd ed. Berlim: Springer, 2005. $366 \mathrm{p}$.

PLATT, J. P.; BEHRMANN, J. H. Structures and fabrics in a crustal scale shear zone, Betic Cordilleras, SE Spain. Journal of Structural Geology, Amsterdam, v. 8, p. 15-34, 1986.

PRAZERES FILHO, H. J.; HARARA, O. M.; BASEI, M. A. S.; PASSARELLI, C. R.; SIGA Jr., O. Litoquímica, geocronologia U-Pb e geologia isotópica ( $\mathrm{Sr}-\mathrm{Nd}-\mathrm{Pb}$ ) das rochas 
graníticas dos batólitos Cunhaporanga e Três Córregos na porção sul do Cinturão Ribeira, Estado do Paraná. Geologia USP, Série Científica, v. 3, n. 1, p. 51-70, 2003.

PRICE, G. P. Preferred orientations in quartzites. In: WENK, H. R. (Ed) Preferred Orientations in Deformed Metals and Rocks: an Introduction to Modern Texture Analysis. Orlando: Academic Press, 1985, p. 385-406.

RAMSAY, J. G. Shear zone geometry: a review. Journal of Structural Geology, Amsterdam, v. 2, n.1/2, p. 83-99, 1980.

RAMSAY, J. G.; GRAHAM, R. H. Strain variation in shear belts. Canadian Journal of Earth Sciences, v. 7, n. 3, p. 786-813, 1970.

RAMSAY, J. G.; HUBER, M. I. The techniques of modern structural geology: strain analysis. New York: Academic Press, 1983. v. 1, 307 p.

RAMSAY, J. G.; HUBER, M. I. The techniques of modern structural geology: folds and fractures. New York: Academic Press, 1987. v. 2, 391 p.

RICCOMINI, C.; SANT'ANNA, L. G.; FERRARI, A. L. Evolução geológica do Rift Continental do Sudeste do Brasil. In: MANTESSO NETO, V.; BARTORELLI, A.; CARNEIRO, C. D. R.; BRITO NEVES, B. B. (Eds.) Geologia do Continente SulAmericano: Evolução da Obra de Fernando Flávio Marques de Almeida. São Paulo: Beca, 2004. p. 383-405.

ROBIN, P. Y. F.; CRUDEN, A. R. Strain and vorticity patterns in ideally ductile transpression zones. Journal of Structural Geology, Amsterdam, v. 16, p. 447-466, 1994.

RODRIGUES, S. W. O.; FALEIROS, F. M. Avaliação de métodos de quantificação da deformação finita por meio de simulações computacionais de deformação progressiva. Revista Brasileira de Geociências, São Paulo, v. 37, n. 3, p. 504-514, 2007.

SADOWSKI, G. R. Estado da arte do tema: geologia estrutural de grandes falhamentos. In: CONGRESSO BRASILEIRO DE GEOLOGIA, 33., 1984, Rio de Janeiro. Anais... Rio de Janeiro: SBG, 1984. v. 4, p. 1767-1793.

SANTORO, E. Evolução geológica do Pré-Cambriano da região de Santo Antônio do Pinhal, SP: importância tectônica das zonas de cisalhamento. 1998. 153 f. Tese (Doutorado) - Instituto de Geociências, Universidade de São Paulo, São Paulo.

SARKARINEJAD, K.; HEYHAT, M.; FAGHIH, A.; KUSKY, T. Heterogeneous ductile deformation and quartz c-axis fabric development within the HP-LT Sanandaj-Sirjan Metamorphic Belt, Iran. Tectonophysics, Amsterdam, v. 485, p. 283-289, 2010.

SCHIMID, S. M.; CASEY, M. Complete fabric analysis of some commonly observed quartz C-axis patterns. In: HOBBS, B. E.; HEARD, H. C. (Eds) Mineral and rock deformation: Laboratory studies.The Paterson Volume. Washington, D.C.: American Geophysical Union, 1986. p. 263-286. Geophysical Monograph, n. 36. 
SCHMITT, R. S.; TROUW, R. A. J.; Van SCHMUS, W. R.; PIMENTEL, M. M. Late amalgamation in the central part of the West Gondwana: new geochronological data and the characterization of a Cambrian collisional orogeny in the Ribeira Belt (SE Brazil). Precambrian Research, Amsterdam, v.133, n. 1-2, p. 29-61, 2004.

SIMPSON, C.; DE PAOR, D. G. Practical analysis of general shear zones using the porphyroclast hyperbolic distribution method: an example from the Scandinavian Caledonides. In: SENGUPTA, S. (Ed.) Evolution of Geological Structures in Micro- to Macro-Scales. London: Chapman and Hall, 1997, p. 169-184.

STIPP, M.; STÜNITZ, H.; HEILBRONNER, R.; SCHMID, S. M. The eastern Tonale fault zone: a 'natural laboratory' for crystal plastic deformation of quartz over temperature range from 250 to $700^{\circ}$ C. Journal of Structural Geology, Amsterdam, v. 24, p. 1861-1884, 2002.

TURNER, F. J.; WEISS, L. E. Structural analysis of metamorphic tectonites. New York: McGraw Hill, 1963. 545 p.

VLACH, S. R. F. Microprobe monazite constraints for an early (ca. 790 Ma) Brasiliano Orogeny: the Embu Terrane, Southeastern Brazil. In: South American Symposium on Isotope Geology, 3., 2001, Pucón. Extended Abstracts Volume (CD). p. 265-268.

VIEIRA, S. R. S. S. Estudo de processos metamórfico-metassomáticos nos Complexos Embu e Pilar, no Bloco Juquitiba, SP. 1996. 210 f. Tese (Doutorado) - Instituto de Geociências, Universidade de São Paulo, São Paulo.

WAHLSTROM, E. E. Optical crystallography. 4th ed. New York: John Wiley \& Sons, 1969. $489 \mathrm{p}$.

WALLIS, S. R. Vorticity analysis and recognition of ductile extension in the Sanbagawa belt, SW Japan. Journal of Structural Geology, Amsterdam, v. 17, n. 8, p. 1077-1093, 1995.

WALLIS, S. R.; PLATT, J. P.; KNOTT, S. D. Recognition of syn-convergence extension in accretionary wedges with examples from the Calabrian arc and the eastern Alps. American Journal of Science, v. 293, p. 463-495, 1993.

XYPOLIAS, P. Vorticity analysis in shear zones: a review of methods and applications. Journal of Structural Geology, Amsterdam, v. 32, n. 12, p. 2072-2092, 2010.

ZUQUIM, M. P. S.; TROUW, R. A. J.; TROUW, C. C.; TOHVER, E. Structural evolution and U-Pb SHRIMP zircon ages of the Neoproterozoic Maria da Fé shear zone, central Ribeira Belt - SE Brazil. Journal of South American Earth Sciences, Amsterdam, v. 31, p. 199-213, 2011. 